University of Louisville

ThinkIR: The University of Louisville's Institutional Repository

Electronic Theses and Dissertations

1944

\title{
A comparative study of a group of institutional and private home children in a public school.
}

Mary Virginia Witt

University of Louisville

Follow this and additional works at: https://ir.library.louisville.edu/etd

Part of the Education Commons

\section{Recommended Citation}

Witt, Mary Virginia, "A comparative study of a group of institutional and private home children in a public school." (1944). Electronic Theses and Dissertations. Paper 2194.

https://doi.org/10.18297/etd/2194

This Master's Thesis is brought to you for free and open access by ThinkIR: The University of Louisville's Institutional Repository. It has been accepted for inclusion in Electronic Theses and Dissertations by an authorized administrator of ThinkIR: The University of Louisville's Institutional Repository. This title appears here courtesy of the author, who has retained all other copyrights. For more information, please contact thinkir@louisville.edu. 


\title{
UNIVERSITY OF LOUISVILLE
}

\author{
A Comparative Study \\ of a Group of Institutional \\ and Private Home Children \\ in a Public School
}

A Dissertation

Submitted to the Faculty

of the Graduate School of the University of Louisville

In Partial Fulfillment of the

Requirements for the Degree

of Master of Arts

Department of Education

by

Mary Virginia Witt

Year

1944 
NAME OF STUDENT: Mary Virginia Witt

TITLE OF THESIS:

A CONTPARATIVE STUDY

OF A GROUP OF INSTITUTIONAL

AND PRIVATE HOME CHILDREN

IN A PUBLIC SCHOOL

APPROVED BY READING CORNITTEE CONPOSED OF THE FOLLOWING MEMBERS:

Jilda Threlkeld

NAME OF DIRECTOR:

J. J. Oppenheimer

DATE: Sept., 15,1944 
A COMPARATIVE STUDY

OF A GROUP OF INSTITUTIONAI

AND PRIVATE HOME CHILDREN

IN A PUBLIC SCHOOL 
CONTENTS

CHAPTER

PAGE

I INTRODUCTION

2

II THE PROCEDURE

6

III ENVIRONMENTAL FACTORS

The Community

The School

The Institution

36

Attendance

47

Summary

58

IV EDUCATIONAL FACTORS Intelligence Tests

Achievement Tests

Summary

$V$ PERSONAIITY FACTORS

Report Card Ratings ' 111

Teacher Ratings

117

Pupil Questionnaires

122

Summary

127

VI RECOMMENDATIONS

129

APPENDIX

131

BIBIIOGRAPHY

140 
LIST OF TABLES

TABLE

PAGE

I Number of Children in the Family from

Private Homes

II Number of Rooms Occupied by Each Family 31

II Number of Days Absent During Term 48

IV Reasons for Absences Among Children from Institutional and Private Homes

$\nabla$ Frequency Table of the $I . Q$. of all the Children in the Sixth Grade Minus the students from the Institution enrolled in a Public School

VI Frequency Table of the I.Q. of Forty Children enrolled in a Public School who Were Members of an Institutional Home

VII Intelligence Quotients of one Hundred Sixteen Private Home Children and Forty Institutional Children Inrolled in a Public School 1943

VIII A Comparison of the Control Group and Experimental Group Based on the Intelligence Quotients

IX Percentage Distribution of Intelligence quotients of Institutional children and Children from Private Homes

$X$ Chronological Ages of Pupils

XI Number of Schools Fach Child Attended During Six Years of Elementary School

XII Number of Schools Fach Child Attended During the Six Years of Elementary Schools

XIII Number of School Terms Repeated by Pupils From Institution and Private Homes

XIV Results of the Progressive Achievement Test in Reading Vocabulary in Grade Placements Administered october 1943 and January 1944 
TABLE

XV Statistical Significance of the Differences

PAGE

Between Forty Institutional Children and Forty Children from Private Homes on the Reading Vocabulary of the Progressive Achievement Test Form B Administered october 1943

XVI Statistical Significance on the Reading Vocabulary of the Progressive Achievement

Test Form C Administered January 1944

XVII Results of the Progressive Achievement Test in Reading Comprehension in Grade Placement

XVIII Statistical Significance on the Reading Comprehension of the Progressive Achievement Test Form B

XIX Statistical Significance on the Reading Comprehension of the Progressive Achievement Test Form C

XX Results of the Progressive Achievement Test in Language in Grade Placement

XXI Statistical Significance on the Language of the Progressive Achievement Test Form B

XXII Statistical Significance on the Language of the Progressive Achievement Test Form C

XXIII Results of the Progressive Achievement Test In Arithmetic Reasoning in Grade Placement

XXIV Statistical Significance on the Arithmetic Reasoning of the Progressive Achievement Test Form B

XXV Statistical Significance on the Arithmetic Reasoning of the Progressive Achievement Test Form C

XXVI Results of the Progressive Achievement Test in Arithmetio Fundamentals in Grade Placement

XXVII Statistical Significance on the Arithmetic Fundamentals of the Progressive Achievement Test Form B 
XXVIII Statistical Significance on the Arithmetic Fundamentals of the Progressivee Achievement Test Form C

XXIX Results in Grade Placement of the Progressive Achievement Tests Form $B$ and Form $C$

XXX Results of the Progressive Achievement Test Elementary Battery Form $B$ as to Grade Pladement and Upper and Lower Quartiles

XXXI Results of the Progressive Achievement Test Elementary Battery Form B as to Grade Placement and Upper and Lower Quartiles Administered to Forty Institutional Children

XXXII Results in Grade Placement of the Progressive Achievement Test Elementary Battery Form B Administered to 1673 Sixth Grade White Pupils in the Louistille Public Schools

XXXIII Teacher Rating of Citizenship of Pupils from Private Homes and Institution on the Report Card of the Louisville Public Schools

XXXIV Personality Ratings of Children by Four Sixth Grade Teachers 
GRAPHS

GRAPH

I Map of the Engelhard School District Showing Three Types of Living Quarters, Religious and. Social Institutions, and Places Contributing Toward Social Deterioration

II Comparison of the Mental Ages in Percentages of a Group of Forty Institutional Children with a Group of Forty Children from Private Homes

III Wonths Improvement in Grade Placement in Reading Vocabualry of the Progressive Achievement Test Administered to Forty Institutional Children and Forty Children from Private Homes

IV Months Improvement in Grade Placement in the Reading Comprehension of the Progressive Achievement Test Administered to Forty Insitutional Children and Forty Children from Private Homes

$V$ Months Improvement in Grade Placement in the Language of the Progressive Achievement Test Administered to Forty Institutional Children and Foty Children from Private Homes

VI Months Improvement in Grade Placement in Arithmetic Reasoning of the Progressive Achievement Test Administered to Forty Institutional Children and Fort Children from Private Homes

VII. Months Improvement in Grade Placement in Arithmetic Fundamentals of the Progressive Achievement Test Administered to Forty Institutional Children and Forty Children from Private Homes 
CHAPTER I

INTRODUCTION 


\section{CHAPTER I}

\section{INTRODUCTION}

Do children who live in an institution and attend a public school differ greatly from pupils who live in individual homes? This question has been of outstanding interest to the writer who teaches in a school whioh has an enrollment one third of which consists of institutional children. The members of the faculty of the school seem to think the children from the orphanages are marked. The following representative statements were made by teachers who deal with the children from the Louisville Baptist Childrens' Home and the Christian Orphans' and Widows' Home.

It is quite difficult to place your finger on the difference between institutional children and those reared in a private home. I have found that the orphan feels that he is in a segregated group and this causes him to feel inferior. The children lack initiative and responsibility and because of this they have a difficult time adjusting themselves with the outside world."

'The teacher's word or appraisal means everything to the institutional child. His school life is based on the teacher's opinion of him. The school seems to be the orphan's chief interest.'

- Children seem very dependent on the teacher's aid in helping them keep their school supplies. They do not feel the responsibility of owmersinip.' 
- I have found the children from the 'homes' are very clanish which is probably due to timidity. They stay with their own little group at Sunday School and even at parties. We are definitely trying to encourage them to be more sociable by having our pupils invite the orphans into their homes.'

It is assumed by leading educators and psychologists that an institutional environment and training leave their mark upon the child.

It is generally believed that the percentage of the retarded mentally defective children in child caring homes is higher than among general school population. This belief may be justified, but objective statistical evidence is neither abundant nor conclusive. Davis' comparative study of a thousand children in orphanages and five hundred rexas school children of the same grades showed $45 \%$ of the public school children mentally below age as against $73 \%$ of the orphanage. I

If this is true, of what value is such knowledge to teachers of institutional children?

With this in mind, the writer has undertaken in the following study to assemble material and interpret facts in order to determine whether there exists an appreciable difference in achievement, social adjustment and personality between public school children who live in an orphanage and those who live in the private homes of the same community. The writer shall endeavor to illustrate by charts, 
graphs, tables and discussions any differences which exist. The knowledge, if such differences exist, should be of value to both administrators and teachers in grading and classifying pupils, in providing suitable curricula, in irnproving instruction and in aiding the institutional chilc in making social adjustments.

The material for this thesis was collected in the following way; through interviews with the children, their teachers, matrons and superintendents, ministers and board members of the institutions, from records of the attendance and census Bureau of the Louisville Public School System, from records of the Louisville Board of Health, from records and case studies of the children who attend the Englehard School, from interviews with members of the Louisville Psychological Bureau, the Board of Christian and Baptist Orphanage and parents of the indiviaual families.

Therefore, it is the purpose of this thesis to show what differences, if any, exist in achievement, social adjustment, and personality between institutional children and children from private homes.

Cooper, John, Children's Institutions, p. 415. 
CHAPTER II

PROCEDURE 
CHAPTER II

\section{PROCEDURE}

\section{A. Selection of group}

The children with which this study deals were enrolled in the four divisions of the Sixth Grade of Victor H. Englehard School, September, 1943 to January, 1944.

In order to set up two groups for the, study all forty institutional children, who were enrolled in the sixth grade, were considered as the experimental group. From the remaining sixth grade children, forty were selected to match the I.Q.'s of the institutional group, as nearly as possible. The Kuhlmen-Anderson Intelligence Test, Grade VI, was administered to the four divisions of sixth grade students in september, 1943. This test was used as it is the one accepted by the Research Bureau of the Board of Education in determining the I.Q. of all sixth grade children throughout the city school system.

The only objective basis for the selection of the two groups was the result of the I.Q. test and the fact that the students were placed in the sixth grade. With so small a group from which to choose it was impossible to pair the pupils by chronological age or sex. 
Pressey, Lincoln, ${ }^{2}{ }^{1}$ Burnham, ${ }^{3}$ and Wreschner have agreed that sex differences in general intelligence, if they do exist, are not great enough to be important and that girls between the ages of 9 and 15 tend, on the average, to surpass boys. This may be due to the fact that they mature earlier than boys.

In view of the above statement and because of the limited number of pupils enrolled in sixth grade, sex was not considered in the pairing of the groups.

\section{1}

L.W. Pressey, "Sex Differences SHown by 2544 School Children on a Scale of Intelligence", Journal of Applied Psychology, II, November, 1918, p.224.

2

E.A. Lincoln, Sex Differences in Growth of American School Children," p. 48 .

3

W.H.Burnham, "Sex Differences in Mental Ability" Educational Review, 152, November, 1921, p.280.

4

A. Wreschner, "New Studies and Mental Differences Between Boys and Giris", Review of Reviews, 63, July, 1923, p.104. 
B. Collection of Data

Data - The experimental data are given under three headings.

1. Environmental Factors - those factors over which a child has little control, such as, the conditions and influence which affect his growth and development.

a. A detailed study of the Christian Orphans' and Widows' Home, the Louisville Baptist Childrens' Home, and the homes of forty children, was made to observe:

(1) Physical conditions of the Home

(2) Daily program

(3) Diet and health

(4) Type of guidance

(5) Provision for study

(6) Facilities for recreation

(7) Ethical training

b. Survey of the institutions was made in the following ways:

(1) Numerous visits to the home

(2) Interviews with superintendent and matrons

(3) Interviews with pupils 
(4) Study of the Survey made September, 1943

(5) Reports from visiting teacher of her contacts with the Home

(6) Pupil analyses of their daily diets

(7) Questionnaire concerning physical conditions of child's home, daily program within the home, opportunities for leisure time activities and ethical training

(8) Children kept five daily records of their diet and activities for 24 hours

c. The survey of the children from the private homes was made in the following ways:

(1) Conference with visiting teacher (visiting teacher contacts every family of children attending school)

(2) Interviews with ministers and Sunday School teachers of the neighborhood churches

(3) Interviews with children

(4) Personal visits to the homes

(5) Questionnaire given to the children (sample copy page 135

(6) Pupils kept a record for 5 days of their daily diet and activities

The comparative study of environmental factors of private homes and institutions was made to see of these conditions show any appreciable difference and if they affect the 
child's school life.

2. Educational Factors - those common skills, abilities and subject amtter learnings in which mastery is required of a sixth grade pupil. These include intelligence, achievement in reading, arithmetic, spelling and language usage. a. The two groups were given the Progressive Achievement Test, Form B in September, 1943 this being the same test given by the Research Department of the Board of Education to determine the achievement of all sixth A students in the city.

b. In January, 1944, Form $\mathrm{C}$ of the same test was given to determine the improvement made during the five months. Graphs and charts were made to show the advancernent in arithmetic, reading, language and spelling, of the pupils during this term. A Ine graph showed the comparison of improvement of the two groups.

c. A comparative record of attendance and punctuality was kept for a period of five months. This record included the reasons for absence, truancies and tardiness. The results of this study were show in tables for the purpose of comparison and were used to show the effect of 
absence and punctuality on advancement of pupils during the term.

d. The children's past school records were consulted to find the number of terms they had been enrolled in Engelhard School, the number of terms they had failed to be promoted, and the number of different schools they has attended. This study was made to show which group had to make the most adjustments to a new sohool environment and its effect on their school achievement.

3. Personality Factors - are the sum total of the constant modes of behavior and reaction in both external and internal aspects.

a. A questionnaire of 65 questions was given to make a study of attitudes, social adjustments and personality of the two groups.

b. The teacher rated each child 1, 2 , or 3 as to Personal Habits, Social Habits, and Work and Play Habits. These citizenship traits are the ones on which the children are rated each month at school. The following is a copy of the citizenship record of the report card used by the Louisville Public School System. 
(1) Personal Habits

Takes pride in appearance

Shows reasonable amount of self-control

Is polite in speech and action

(2) Social Habits

Shows good sportsmanship

Helps to carry out suggestions of the group

Respects public and private property

(3) Work and Play Habits

Has orderly habits of work

Makes good use of his time

Shows self reliance

originates new enterprises for self and group

c. Children wrote essays on

(1) How I Spend My Leisure Timo

(2) What I'd Do With Fifty Thousand Dollars

(3) My Life's Career

(4) Books I Have Enjoyed

In order to answer the question, "Do institutional children differ greatly from children of private homes?" the results of these procedures were studied to get a total picture of the children of the two groups. 
CHAPTER III

A COMPARATIVE STUDY OF THE ENVIRONMENTAL FACTORS 


\section{CHAPTER III}

\section{A CORPARATIVE STUDY OF THE ENVIRONMINTAL FACTORS}

In answering the question, "Are institutional children different from children in a private home?" - a study of the environment of the child had to be made. This survey includes a study of the community, the school, the private homes and the two institutions.

Whaking a survey of the group of forty people from private homes was very difficult as most of the material had to be obtained by means of questionnaires. The visiting teacher, the principal, and the minister and sunday school teachers were a great aid in collecting information. Like Whitley they realized that the environment plays an important part in the development of a child.

The more one knows about the whole environment of any child the better she is equipped to give him that which he needs most. Insufficient or improper nourishment, poor living conditions, inherited abnomal tendencies, these and a host of other factors, all have their influence on a child's behavior. How much time do the children spend with the rest of the family? Are mothers and fathers comparative strangers to their children, or trusted companions? Are parents well-informed or ignorant, aesthetically cultured or cheap and tawdry in their tastes? How do they spend their leisure time? What are their habitual recreations? Do they attend church? Are the parents in harmony with each other, or is there 
constant friction, suspicion, Impatience, sarcasm in the atmosphere of the home?

How are the children treated? Are they held to any responsibility? Are they given money whenever they ask or do they have a weekly allowance? Have they a definite bedtime? Have they a place to play in the home?

All these things will make the greatest kind of difference in moral development. 1

Everyone realizes the importance of environment in the development of a person. The environment touches every phase of a person's life. Freeman carried out an investigation with a group of children in foster homes to determine whether the intelligence of a child was affected by the character of his environment.

A group of children were tested before placement and then retested after sereral years of residence in a foster home. A comparison of their ratings on the tests gave evidence of a significant improvement in intelligence, as measured by intelligence scores. A study of certain sub groups showed that the children in the better foster homes gained considerably more than those in poorer homes. Furthermore, the children who were tested and adopted at an early age gained more than those adopted at a later age. These facts seem to indicate that an improvement in environment produces a gain of intelligence. 2

\footnotetext{
1

Mary T. Whitley, A study of the Primary child, p.18.

2

National Society for Study of Education Yearbook XXVII, Part I, The Influence of Environment on the Intelligence, School Achievement and conduct of Foster Children, Frank Freeman, Karl Holziner, Blythe HitchelI.
} 
In many studies of individuals it has often been found that "before and after" tests show changes in intelligence after children have been changed from one environment to another. Gains in I. Q. have been found after children have been moved from institutions or underprivileged homes to a better environment.

In a study carried out in a nursery school at an orphanage, by Skeels, it was found that the children who attended the nursery school showed an average gain of 4.6 points in I.Q. The control subjects who did not attend this school showed an average loss of the same amount.

In order to get an understanding of the children a study of each child had to be made. It was necessary to know about his environment, his physical and mental ability, his attitudes and wishes, and his conceptions of life itself. Kilpatrick says this is the "total situation". This idea is ummed up in the following statement:

The more closely we look at life itself the newer biologic view of organism helps us to understand behavior as possibly never before. Any organism is seen as a self regulative pattern, inextricably interwoven with environment. When by a change either, within or without, the organism, the equilibrium of the organism is upset there ensues a strain which we variously call need, want, wish, drive, preference, or the like. Consequent upon this strain there ensues moveinent di-

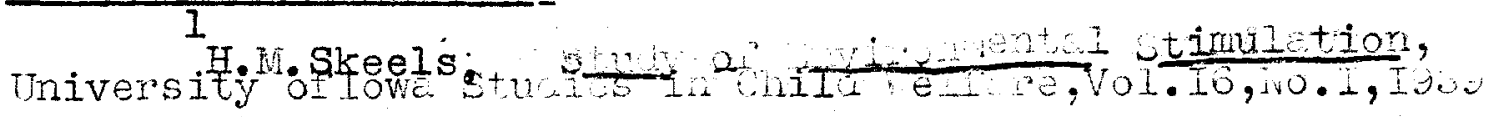


rected toward the environment which tends to restore the lost equilibrium. - Any organic activity is as much the affair of the environment as it is the organism. Any habit of the child belongs as truly to the situation as to the child for it joins both together, and the situation is the actual total situation in all its particular manifestations to which the child is in fact sensitive. . . The whole child with all its effectual past now actually located in a present concrete $s$ situation with all its effectual connectedness - this is the only unit. I

To know the whole child should be the aim of a person making this study. An effort has been made to obtain as much information as possible regarding social and personality adjustment, as well as his academic achievement.

The community, the school and the home are the three major influences in a child's life. A study of each of the factors will follow.

\section{A The Community}

The Victor H. Engelhard School is located at 119 East Kentucky street. This is in the central district of the city and as a consequence the pupils of this school are not living in the most favorable part of Louisville. The neighborhood has changed from a wealthy, cultural residential section to a rooming and boarding house district.

1

W.H.Kilpatrick, A Reconstructed Theory of Education Process, pp.3-7. 
The fact that 95 percent of the children chosen for this study live in rented dwellings or rooming houses show that the mobility of the neighborhood is extremely high. only two families of this group own their homes.

In the Housing Bulletin on Block Statistics Dr. Truesdell states that there was a total of 481 structures or buildings in tract 61 , which includes the school community. From these structures 1234 dwelling units have been made. 746 of these apartments have no private baths. At first the rooming and boarding houses were occupied by a very respectable, industrious class of people. As more homes were converted into rooming houses, the people living in them were more underprivileged than formerly - people with low standards of living and morality, degenerate drifters Prom other cities.

on a trip with the visiting teacher it can be observed that it is not unusual for a large family to be living in one or two rooms. Often the furniture consists of a bed, table, and a chair. Many times the family sleep and eat in the same room. This type of apartment is often found on a third floor or attic or back room over some business concern. The lighting conditions and ventilation are poor, to say nothing of the crowded conditions.

1

Ieon E. Truesdell, Housing, Louisville Block Statistics, $1942, \mathrm{p} .18$. 
Sometimes when investigating why certain children came to school dirty it was found that several families user the same bath, or that there was no bath in the house, and all water for bathing facilities had to be heated upon the gas stove. The children who live under these conditions are to be commended for their appearance, for in the majority of cases they do the washing and ironing of their clothes.

A part of the school district, on Preston Street, abounds in cheap restaurants, second hand stores, saloons, and pool houses where alleged gambling and drinking take place. Negroes, with undesirable characteristics are fast becoming in the majority in this neighborhood. Truesdell's report stated there are 170 non-white adults in the census tract 61 . In spite of the deterioration of this community it still remains an interesting neighborhood for children. Within walking distance of the school are two parks, a swimming pool, two public libraries, twelve churches, two of which hold regular bi-weekly recreational and Bible study periods for the children in this district. There are two hospitals, a dairy, garages, and filling stations by the scores, a fire engine house, and two high schools.

The high schools play an important part in the life of the children as they watch all extra-curricular activities, with great interest, often with so much enthusiasm that they

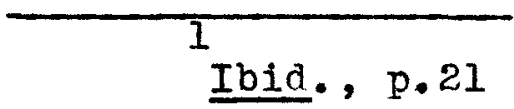


become a nuisance to the janitors of the school in the late afternoons. It is an asset to have a high school in the same community as an elementary school, as each student looks forward to the time that he, too, will be a part of this school. Engelhard School chilaren are again fortunate that the Memorial Auidtorium is so near. All children's concerts and lectures are well attended by the pupils as about twenty per cent of the sohool enrollment buy season tickets. The proximity pf the building eliminates all problems of transportation since the pupils and teachers walk over.

The Y.M.C.A., although out of the school district, holds the interest of the boys. Each child is encouraged to accept a part payment membership from the $Y$. Almost every boy above the age of nine has had a membership at the $Y$. Some of them do not enjoy these activities and soon drop out, bu the majority keep going several afternoons a week. A few boys carry papers in the afternoons and prefer to go to the $Y$ at night. These many places of interest when used properly prove to be both enjoyable and educational to the children of the comriunity.

\section{B The School}

Victor H. Engelhard School, an elementary public school of six grades, is housed in a brick building eighty years old. It has three stories with rather small rooms, no cloak rooms, 
and very little modern equipment. Three classes are held in portable buildings which are not conducive to study, as the noise from the street and playground is very disturbing. There is very little space for recreational activities of any kind. The lunchroom and toilet facilities are separated from the main building.

Although the building is old and lacks many of the modern equipments, it is made quite attractive by the children and teachers. Each teacher prides herself on the appearance of her classroom as she feels that this room must interest the child, as he is a part of it for several hours a day. Children are often heard to remark about the different new articles, pictures or paintings which they have seen in different rooms.

District lines Victor H. Engelhard School

Grades: $1-6$ and Kindergarten

Northern: Broadway and Jacob Street

From the intersection of $3 r$ and Broadway east (including Broadway) to lst, then east (not including Broadway) to Floyd, then south (including Floyd) to $\mathrm{J}_{\mathrm{a}} \mathrm{cob}$, then east (not including Jacob) to Preston.

Eastern: Preston Street and Jackson Street From the intersection of Jacob and Preston south (including Preston) to Breckinridge, then east (including Breckinridge) to Jackson, then south (including Jackson) to Oak.

Southern: Oak Street and Ormsby Avenue From the intersection of Jackson and 0ak 
Map of Engelhard School District showing three types of living quarters, religious and social institutions, and places contributing toward social deterioration.

\section{LEGEND}

Map of the School District

- Boundary

- One side of street only

- Area of rooming houses and old houses converted into two and three family dwellings

Schools

Churches

\%ur Orphanages

+ Hospitals

- Residences of children in the study

- Rooming houses

- Dwelling places in rear, and on second and third floors of old business houses

- Saloons, cafes, and pool rooms

Negro residences 
Map of Engelhard School District showing three types of living quarters, religious and social institutions, and places contributing toward social deterioration.

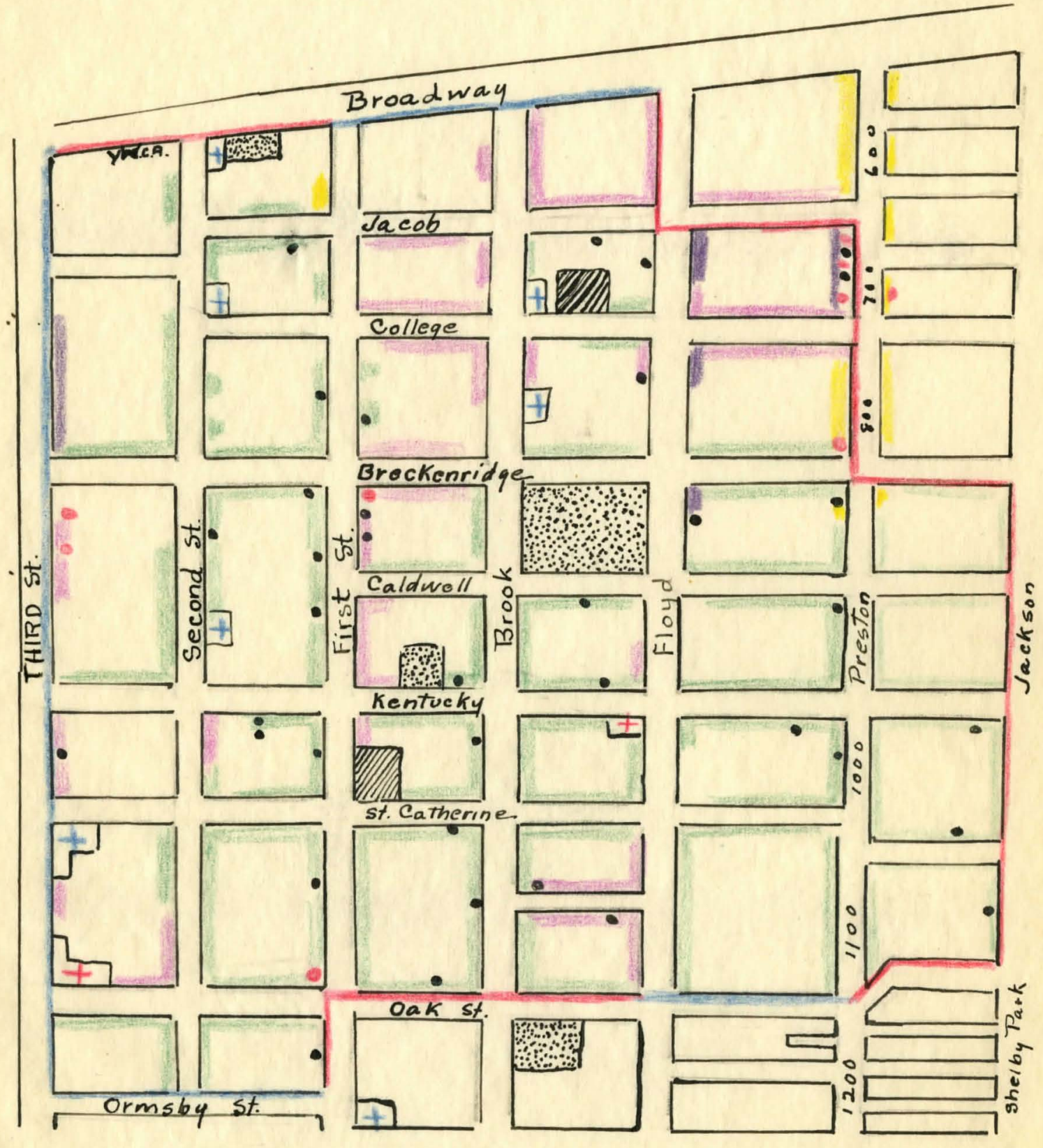


west (not including $0 \mathrm{ak}$ ) to Floyd, then west (including 0ak) to lst, then south (including lst) to ormsby, then west (not including Ormsby) to $3 \mathrm{rd}$.

Western: Third street

From the intersection of 0rmsby and 3rd north (including east side of $3 r d$ ) to Broadway. 1

A factor which makes the Engelhard School community different from other schools is the location of the Baptist Childreng' Home at 1022 First, and the Christian Widows' and Orphans' Home at 225 East College Street. Approximately one third of the school's enrollment is made up of children from these institutions.

All forty children from the institutions who were enrolled in the sixth grade were selected for this study. These children have a varied background, as they come from many sections of the state. Many of them had attended school only a few months out of the year. One can see that educational requirements for entrance in these homes are not so strict because of the many children who are over-age when they enter the school. According to the latest policy in the Orphans' Friend in November, 1940:

$$
\begin{aligned}
& \text { (boys up to nine years of age, girls } \\
& \text { up to twelve years of age) is eligible }
\end{aligned}
$$

1

Record of School District Lines - September, 1943 Files of Superintendent's Office, Louisville Board of Education, Louisville, Kentucky. 
for admission to the Home if sound of body and mind; and their admission is recommended by the Baptist Church, and if those having rightful authority over them will commit them legally to the custody of the Home as required by our Charter and By-laws. . . . nor shall any child be admitted who, from character or from unsoundness of body or mind, is likely to interfere with the morals or health of other children in the Home, or otherwise injuriously or adversely affect them. 1

The children selected from the individual homes were chosen by their I. Q.'s to match the institutional children. Seven pupils from private homes had treveled from state to state with their parents who were seeking work. Nine had come from county schools where they had attended only a few months during the year, and two had not even enrolled in a school the preceding year. Others had spent their whole school career in Engelhard School. Thus, this group also had had a varied background, but it represents a cross section of the school enrollment during the period, September, 1943 to January, 1944.

A Study of the Children from Private Homes. The following information about the private homes and habits of the forty children selected for the control group in this study were obtained from informal interviews with the children and

\section{1}

Report of a Survey of the Louisville Baptist Orphans' Home made by Child Welfare League of America, New York city. 
with the school visiting teacher, a questionnaire, visits, into the homes and from compositions written by the children about their personal experiences. Most of the families of the private home group are not large as may be seen by the chart.

\section{TABLE I}

Number of Children in the Family from Private Homes

\begin{tabular}{|c|c|c|c|c|c|c|c|c|}
\hline $\begin{array}{l}\text { No. of Children } \\
\text { in family }\end{array}$ & 1 & 2 & 3 & 4 & 5 & 6 & 7 & $\begin{array}{l}\text { Total } \\
103\end{array}$ \\
\hline $\begin{array}{c}\text { No. of Families } \\
\text { represented }\end{array}$ & 8 & 16 & 8 & 4 & 2 & 1 & 1 & 40 \\
\hline
\end{tabular}

Eighty percent of the children in this group come from families with three or less children. Only eight children have four or more siblings in their families.

These families live in furnished rooms or rent small apartments. Only two children stated that their parents owned their homes. Five children who lived in furnished rooms said that they would only be in the city a short time and that their family owned a home in another city. More than one third of the group live in either one or two rooms. The smallest family consisting of one child had the largest home, a six room house, while the family of seven children filled to capacity a small dark four room apartment. Only three children indicated that they possessed a room of their own. Some of these 
apartments, although small and with very little furniture, were attractively kept. Many were exceptionally clean and orderly, in spite of the fact that the one room might serve as kitchen, bedroom, and living room. In one of the homes a sixth grade child welcomed the visitor. The girl was the housekeeper and told with pride how she was able to come to school and care for the home, too. Mothers have told the writer that they do not like the crowded conditions with which they have to live but that it seems impossible to find dwellings in a better location now.

The very poorest of families are also represented in this group. Six homes are in the rear or over business houses. The entrances are like long, dark alleys and the interiors are not much better. The sanitary conditions are poor and and it was found in one place that one bathroom was shared by eighteen people. Some of the apartments are attic rooms with a few pieces of second hand furniture.

Most of the childiren live in a few rented rooms. Some, however, occupy the cottage type house where a person can stand at the front door and see straight back to the kitchen. We are told that the house does not make a home, and it is the truth for the writer found some "homes" among the poorest of dwellings.

In checking the occupations of the fathers, an interestIng variety was discovered. Among the fathers we find: 
8 defense workers

2 musicians

2 salesmen

2 mechanics

2 laborers
1 insurance agent

1 carpenter

1 baker

I taxi driver

1 welder

Four fathers are in the Army, twelve others are not living at home, and three are deceased.

The war has certainly changed things for these people. In eight cases both mother and father are at work. Twentyfive mothers are gainfully occupied outside the home. The mothers' occupations are as follows:

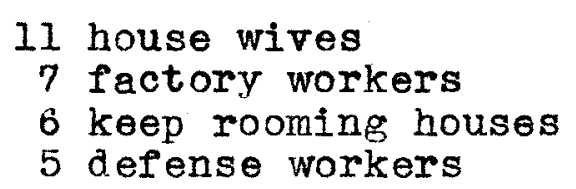

11 house wives

7 factory workers

5 defense workers
3 sales ladies

2 taxi drivers

1 baker

I gasoline station attendant

Three of the children do not live with their parents, but with relatives.

Since so many of the mothers work outside the home it has put an extra burden on the father and the children. The children often have to do the purchasing of the food and the cleaning of the home. The writer has seen shoulders thrown back and eyes dance when the children proudly state that they are the cooks in their homes now. Several of the girls say that they clean house before coming to school. Some of the boys they have the food purchased and regetables ready to cook when mother comes home. Most of the group seem to know the value of money and the cost of particular foods for they have had 
the experience of purchasing them. Contributing to the family as this group is doing really develops responsibility and initiative. If the child has been properly trained and is dependable this experience of a few hours of extra responsibility may prove to be a blessing in disguise.

However, the working of both mothers and fathers has its disadvantages. The child often has to awaken himself, get ready for school, eat a cold breakfast, or cook it himself, lock up the house and then come to school. The day certainly has a brighter outlook if he has someone to tell him a cheorful goodbye. Then nothing is worse than to come home from achool and enter an empty house, with mother gone. Two children asked if they could be permitted to leave school at the first tap of the bell so that they could get home in time to see their mother before she left for work. If they did not hurry home, the only time they could see her was during the week-end, as she did not get in until after they had gone to bed. Another boy said he hated to go home for his father; mother and sister were never home and he got lonesome. He usually spent most of his time in the afternoon and until bed time with some men in the pin ball repair shop. His one ambition now is to manufacture pin ball machines. $\mathrm{He}$ said, "Why, those men are teaching me to do repair work, and they trust me. I get to package all the change and no one stays in the room to watch me. When someone really trusts me I 
wouldn't think of being dishonest." If for no other reason than the location of the place where this boy "hangs out" he would be much better off under one of his parents' supervision and playing with a group og boys. Another chidd said, "I just hate to go home. There's nothing to do after I've straightened up the house. Nother and I used to have a good time before Daddy went to the Army."

It seems that the girls can find sorething to do and seem better satisfied with their parents working than the boys. It may be that the boy feels more lonely and insecure, as he is not familiar with housework, and beling left alone. Miss Henrietta Addition, head of the Westfield, N.Y. State Farm Reformatory for Girls, states that two needs are paramount in the life of every child.

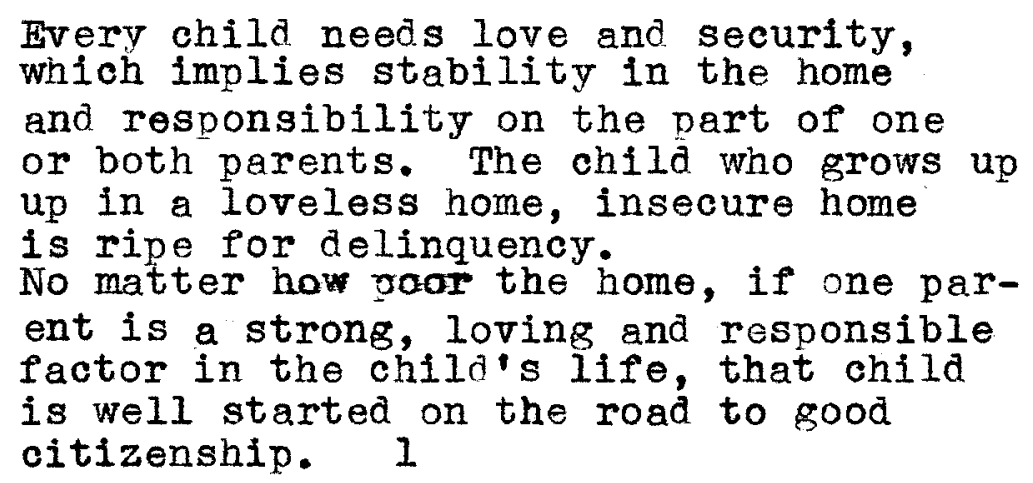

When mothers are working the proper tyoe of guidance

cannot be given by a landlady or some housekeeper. Then when parents come home there is little time to be with the children

1

Henrietta Addition, "Bad Girl Had a Bad Home", Loui.sville Courier-Journal, July 23, 1944. 
as they wish some recreation themselves, or there is work to be done in the home. The child gets little assistance with his school work from his family. Eight children are helped regularly at home with their school work. All homework is done and checked before they go to play. Fifteen are aided sometimes. The rest of the group are never or very seldom helped with matters pertaining to school. Most of the homes are not conducive for study. When one notices the few number of rooms in the home, and the size of the family, Table II, he realizes that it is difficult for the ohild to concentrate under these conditions.

\section{TABLE II}

Number of Rooms Occupied by Each Pamily No. of rooms

in each Unit

No. of

Families

1

$4 \quad 11$
2
3

4

5

$9 \quad 15$
5

1

These families live in rather crowded quarters. More than one third of the group live in one or two rooms. Only three children indicate that they had a room of their own. Each of the forty children possessed a library card and 60 percent of them were using the library regularly. Several boys earned their Red Cross pins by serving fifty hours last term at the Red Cross Chapter House. Three children took advantage of the free art classes at the Art Center. Three took music lessons. Many of this group had season 
tickets to the concerts given by the Cincinnati symphony orchestra. Any day one passes the Male High a few children from this group may be seen playing football or baseball in the school yard. There are few places to play in this neighborhood, as the yards are either small or the children are not allowed to play in the yard. A few alleys which are not frequented by cars are used extensively as playgrounds. Shelby Park is really a godsend to this community because of the playground, swimming pool, and library.

Three boys and four girls are members of scout troops which meet in the neighborhood. Four boys have joined a Junior Commando group under the leadership of a high school boy. They meet with other members and drill each saturday in the school yard. Several boys and girls are members of the Y.M.C.A. or Y.W.C.A. Two of the neighborhood churches have Bible School one afternoon a week for the children where they have a short period for Bible study and an hour and a half of handicraft work. Twelve people from this group have choir practice one afternoon a week at school.

As the community is near the center of the city the children like to keep up with the latest picture shows. The result of the questionnaire showed that three pupils out of the group saw ten shows during the month of November; thirteen saw over three shows; twelve saw only one and three children did not go to picture shows. A picture show is a special 
treat to the child and is often given as a reward by the parent.

Since so many odd jobs are now available for children of these ages, a child does not have to ask parents for money, but can earn spending money during his spare time. The inquiry ahowed that 25 children from the private home group earned an income.

Types of Work Done by Children in Private Home Group

\begin{tabular}{lc} 
Type of work & No. of children working \\
do housework & \\
wash dishes & 8 \\
go to store -run errands & 4 \\
keep children & 3 \\
carry paper routes & 3 \\
sell papers & 3 \\
clerk in store & 2 \\
\hline
\end{tabular}

The children besides working outside the home often have an added responsibility of checking on thie own personal health habits. Parents do not have the time to supervise the children as they once did.

Since the children often plan the meals they may not be as healthful as when the mother planned them. As nutrition and diets were stressed at school, it was hoped that some teaching may have carried over into the home. After a survey of the week's diet had been made it was impossible to say how much teaching had taken effect. 
The following menus were three sample diets which were copied from the records of three pupils who made an analysis of their foods.

\section{Breakfast}

I
chipped beef with gravy on toast coffee

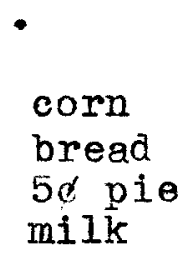

pork chops - gravy potatoes bread milk
II

orange
toast
jam

Lunch

hash
crackers
milk

\section{Dinner}

fried potatoes
green beans
peas
rolis
milk

\section{III}

cereal

egg toast milk

spaghetti orange crackers candy bar milk

$$
\begin{aligned}
& \text { roast } \\
& \text { creamed potatoes } \\
& \text { lettuce } \\
& \text { biscuits - jelly } \\
& \text { hot tea }
\end{aligned}
$$

One can see from the menus that there is a definite lack of freah fruit and vegetables. Is this because mothers are working, and do not have time to prepare fresh food? only three children said they had actual charge of planning meals. Most mothers left a grocery list for the child.

The children are very conscious of food values when they buy their lunches in the lunchroom. They have a great deal more money to spend then formerly, and most of them buy a well balanced lunch at school. This may be due to the teacher's supervision. of course, there are a few students whose parents 
give them money abd who stop at the corner grocery. The result is a lunch of marsh, allowy cakes or soggy pie.

Whether or not the diet has had its effect upon the health of the child during this study is difficult to say. However many absences were caused by upset stomachs. It is known that the personal illness of the child is the largest single cause for excused absences. The maintenance of good health is therefore an important factor in school attendance. The children are watched carefully at school for any signs of illness.

If a child is ill, after a careful investigation has been made as to whom will care for him, since so many mothers work, he is sent home with a note. Often a child must be cared for by the landlady. Sometimes mothers are called from their work. If the child were quite ill it might be necesgary for the teacher to take him to the home of a relative.

Each child is given an examination of eyes, skin, throat, and teeth, at the beginning of each term. The results are placed on his health card and copy sent to his parents. Arrangements are often made for tonsilectomies at the General Hospital and dental care is given for the asking at the Dental clinic. Many children from Engelhard School take advantage of these services. It has been noticed that correction of teeth defects must be closely watched in the group from the private homes. 


\section{The Institutions}

The Louisville Baptist Childrens' Home

The Louisville Baptist Childrens' Home was established in 1869 to care for children whose parents were killed in the Civil War.

The main building is a large three story brick erected at 1022 First Street, in a deteriorating residential section of the city. It is out of date in style and plan but is well built and preserved. The laundry and heating plant are located in the rear of the main bullding. Most of the dwellings within several blocks are now boarding and rooming houses. Schools are easily accessible, with an elementary school only two blocks away. There are three Baptist Churches, two Iibraries, two parks, and the Memorial Auditorium within walking distance.

The main building seems to be in good repair bu the interior decoration seems rather drab in appearance, since brown and tan, or tan and green colors are used throughout the building. The first floor contains the office, a living room, chapel, dining room, pantry, refrigerator room, the small boys' dormitory and playroom, study hall, matron's and housekeeper's rooms, sun porch, baths, and long dark connecting halls. Ample provision is made for removal of the 125 children in case of fire, as there are three stairways and a spiral slide 
escape which is at the rear of the building.

The second floor consists of dormitories, rooms for the matrons, playroorn, living room, and baths. There are separate toilet and bathroom facilities for each dormitory. The large glassed enclosed porches are used as the children like. The attic happens to be the general storeroom. "The contrast in appearance and attractiveness between the boys' dormitories and the girls' is quite noticeable. Every effort had been made to make the living quarters of the girls' attractive, while there seemed to be no evidence of interest in the boys' surroundings. Although one matron felt that "boys don't care", one child had made an effort to add to his surroundings by putting a picture of a dog and a small silhouette on the wall by his bed. Another had tacked a world map above his double decker bed. No other sign of life or interest was in the boys' dormitory." At school when a child gave an unusually well-drawn picture to the teacher, he was told to keep it, with the suggestion that he put it up in his roim. He immediately replied, "Oh, you keep it. Some of the boys will just tear it up if I take it home." Most of the dormitories seemed dark, since all the lights were in the ceiling. The playroom and dormitories always had to be lighted by electricity, even in the daytime. The playrooms were sady

\footnotetext{
1 Child Welfare League of America, Report ot Survey of the Louisville Baptist Home, September, 1943, p.43.
} 
lacking in play equipment. There were few games, or personal possessions. During the holidays, toys are very plentiful, but are soon destroyed as they are not usually the permanent type. The children are encouraged to play outside if the weather permits. This playground is very inadequate, but it at least gets the children in the sunshine. The favorite sport of both boys and girls is baseball. They have a small diamond which is constantly in use. Quite often the "Home" team will play a team in the neighborhood. The children of the community are invited in to see the game. Several swings are placed on one side of the yard. They seem to be occupied mostly by the younger children. Two boys had tried to have a garden of a few plants in a tiny space in the corner. In the Report of the Survey of the Louisville Baptist Children's Home, made by the Child Welfare League of Aderica, Mrs. Kate Bullock Helm said that the institution was to be commended upon the physical care given the children. An ez- . cellent volunteer pedistrician, the chief of a medical staff, is on call, and drops in when possible. When a child enters the home he is given a thorough examination, which includes the Tuberculin test, Wasseman and Kahn, Dick and Shick Tests, G.C. Smear for girls. Children with positive smears are not accepted in the institution.

In a letter of $36-10-27$, replying to a request for the 
admission of a child to the Baptist Children's Home, is this staternent:

Doctor is not accepting any child in the institution without first giving them a thorough trial. We will take the child into the Home and keep him two weeks, or longer, and then notify you if he measures up to our standards. ithis is a recent ruling passed.

A health record is kept on each child. A practical nurse is on constant duty and is usually kepy busy as the chiliren bring their complaints to her. A "nurse line" is kept after breakfast and before supper. Colds are isolated at once. Serious illnesses are always under the care of a physician, and severe cases are sent to a hospital. The school nurse keeps in constant contact with the "home" nurse.

The increase in height and weight are always recorded on the child's report card. This weight is again checked each month by the nurse. If a child is not gaining he is put on a special diet. The children seem to be well fed. The children recorded all foods eaten during the first week of November. The following menu was taken from one of the children's records when he was evaluating his diet.

Breakfast

hot sereal

toast and syrup eggs

milk
Dinner

meat and gravy mashed potatoes peas

bread and milk

\section{Supper}

beans potatoes bread milk

\section{1}

Report of Survey of the Louigville Baptist Orphan's Home, made by Child Welfare League of America, Inc., September, 1943 p. 65 . 
When the diets were followed day by day, it was found that chickens, eggs, and milk were frequently served. However, more green vegetables and fruits should have been used. The children from the Baptist Home bring a sandwich and piece of fruit for lunch at school, and eat their main meal of the day after school.

The day of the uniform for orphans is past. The children from the institutions are well and attractively dressed. Their clothes are always neat and clean. The older girls often make or help make their dresses. When new clothes are to be purchased the child is often allowed to choose his own. This experience proves to be enjoyable and valuable. The teacher always knows when it is time to purchase a new wardrobe for she is often consulted.

There are many outstanding factors at the Home which provide for good mental health of children, which possibly offset many difficulties in an institution. The children mix freely with people outside the orphanage. As they attend church and school in the neighborhood they become a part of the community. All children have opportunity to visit in homes of friends in the city who take them out for dinner or over the week-end. The institution also has access to the facilities of the Mental Hygiene Clinic of Louisville. A social worker is to be added to the staff of the gome which will aid a great deal. 
The general atmosphere of an institution determines the moral training rather than any formal moral instruction. There was always a spirit of cheerfulness and happiness when the writer was visiting. Children rushed out to the hall to greet her or called from the upstairs. The dark hall soon became unnoticed amid the homelike atmosphere. There was, apparently, a good relationship between most of the children and their matrons and a real feeling of justice between the assistant superintendent and children. The children in both homes are responsible to the matron for discipline. The usual problems which require discipline are disobedience, impudence, lack of cooperation on part of older girls, refusal to accomplish work, talking back, stealing, lying, girls slipping out. The common methods of punishment used in the institution are: deprive a child of privileges; have him sit in a chair; isolation; "paddle - when necessary, whip"; "talk the matter over with the child"; spank; "make him ashamed of himself"; sit and read; polish floors; apologize; put to bed. The workers in the institution are trying to use the method of rewards for work well done, or for good behavior, rather than punishment for wrong doing. The one award all children look forward to is ten days at camp. Each child has tthis privilege if his conduct warrants it. Sometimes, when the matron overlooks things, every child over nine years of age gets to go. 
One of the problems of the institution is guidance in the right use of leisure time. The Home subscribes to very few magazines. Only a few children make use of the libraries. The music teacher at the school has organized a choir, and a few of the chilaren are members. The boys are not interested as they think it is "sissy" to have choir practice twice a week. Some of the talented children are allowed to take piano lessons and dramatics. A few radios are available but not enough to suit the tastes of the children. Quite often two or three children will agk if they can use the radio in the matron's room to listen to a specific program.

During the winter some of the boys are allowed to go to the Y.M.C.A. and a few are members of scout groups. The younger boys had an airplane modeling club and seemed to take a great deal of interest in it. Various Sunday School classes entertain different age groups regularly. This gives the children wholesome interests which they enjoy. Some are allowed to attend the neighborhood picture show on Friday night. While the school term is in session the problem of leisure time is not so great as most of the interests and activities center around the school.

When the children have returned home from school, changed clothes, and had their dinner, they go to the study hall. This period lasts twenty minutes for the younger children to forty- 
five minutes for the pupils in the elementary grades. If extra time is needed to study, it is provided after dinner at night. Several high school girls are usually in charge of the study hall, and aid the children in their difficulties. The assistant superintendent and the secretary often help some of the slower students and those who have had to be absent irom sokool. The students are also quite helpful to each other. Often a group, all from the same grade, may be seen coaching one another, or a child.may be observed working with a younger sister or brother. Quite often an older student will ask the teacher, Miss _. will you tell me how to help Joe in his arithmetic? I just don't know what's the matter with him." or "If you'll show me that new way to subtract, I'll try to help Mary." There always seems to be a very helpful attitude among the group.

The study hall is equipped with imnovable desks which accomodate 25 people. There are several sets of out of date reference books, and some books of fiction. The junior and senior high students are allowed to get books from the Public Library but there is no provision made for the younger children. Books are often given to the pupils as gifts but these are soon worn out, as they are passed from student to student. Very few magazines are seen, most of them being old copies which people had sent to the institution for the children 
to use to obtain plotures for strap books. The only newspapers the children read are those belonging to the matrons. It is indeed a scramble when current events have to be taken to school, for it is "first $\operatorname{com} \theta$, - first served".

\section{The Christian Widow's and Orphans' Home}

"The Christian Widow's and Orphans' Home was established in 1872 by the Christian Churches of Kentucky. The building is an attractive three story stone and brick structure erected at 225 East College Street. At one time it was in an excellent residential section of the city."

The building is now out of date in style and plan but is still well preserved. The dwellings surrounding the home are boarding and rooming houses. A negro section of the city is within a block of the home. There are three Christian Churches, two libraries, two parks and the Memorial Auditorium within walking distance of the Home. The two buildings, one for the widows and the other for the orphans, are very well kept. The first floor of the children's home contains two living rooms, an office, chapel, dining room and kitchen. The second floor consists of dormitories and baths, playroom and matron's quarters. The third floor is used for storage. The day the writer visited in the home the children

\footnotetext{
W.H.Slingerland, Child Welfare Work in Louisville, p.47.
} 
were amusing themselves by playing guessing games as suitable playroom equipment is lacking. When the children have finished their special duties such as ironing, polishing floors, cleaning bathrooms, dusting and washing dishes, they are anxious to go into the yard. Their special interest is in playing baseball and football. They like to play at night as the yard is equipped with the proper lighting facilities. Some of the boys are especially interested in keeping the front lawn attractive. Each child takes a great deal of pride in the appearance of it, so they play in the back yard.

The physical welfare of each child is supervised by the individual matrons, assigned to various age groups. Serlous cases of illness are sent to a hospital as a trained nurse is not employed by the home. All contagious diseases are isolated at once. Regular visits are made to the dentist. The matrons watch the decrease or gain in weight of the children. Each matron is definitely responsible for her group. If the matron is interested and has the time, she gives indivual help to the child in his school work. The length of the study period and the checking of the child's school work is left up to the judgment of the matron. The writer has noticed that some groups of pupils are interested in current events and can discuss the happenings of the day. Could the interest be traced to the fact that the matrons discuss these affairs with her group? 
There is a definite lack of up to date reading material in the home. The orphanage possesses a very inadequate library, however the children never use it. only the high school students are allowed to use the Free Public Library which is withing walking distance as "the Home does not want to pay for lost books".

The children buy their lunches which must consist of milk, a sandwich or fruit, and a cake, from the school cafeteria. Their dinner or main meal is served at five $0^{\prime}$ clock. The following menu is one served at the home during the time the children were studying a unit on Foods at school.

Breakfast

oat meal

gravy

toast-preserves

milk
Lunch

sandwich

cookie

milk
Dinner

spaghetti apple sauce bread milk

The writer questions whether the lunch provided at the school is sufficient, for the chilaren eagerly accept food from other members of the class. On this particular day there is a lack of fresh vegetables and fruits.

The children enter into the social and religious activities of the church. They are often invited into the homes of the church members who are interested in their welfare. They always attend the parties given by the young people of the church.

The two events which the children anticipate all year 
are the picnic at Fountain Ferry Park and the camping trip in the summer. The Home owns a camp near Winchester, Kentucky and for several years the children have moved there for the summer.

Matters of discipline are usually left in charge of the individual matrons. The same rule is true as to the granting of special privileges. The children seldom get to participate in extra curriculum activities which are held after the regular school hours; such as, the competitive games, children's concerts, or excursions. It is with fear and trembling that a child goes home if he has been kept a few minutes after school hours because of misbehaviour. If he is late returning home he is punished. Punishment when a child is late curbs the tendency for the child to loiter on his way from school as the matron does not come for the group.

\section{School Attendance}

A child's environment greatly effects his school attendance and punctuality. Since regular attendance contributes to satisfactory achievement, a comparison of the cases of absences and the causes was made.

The number of cases of absence has increased during the past year. kiany cases can be traced to the lack of supervision in the home. Table III shows the number of days absent for each group. 


\section{TABLE III}

\section{Number of Days Absent During Term September 1943 January 1944}

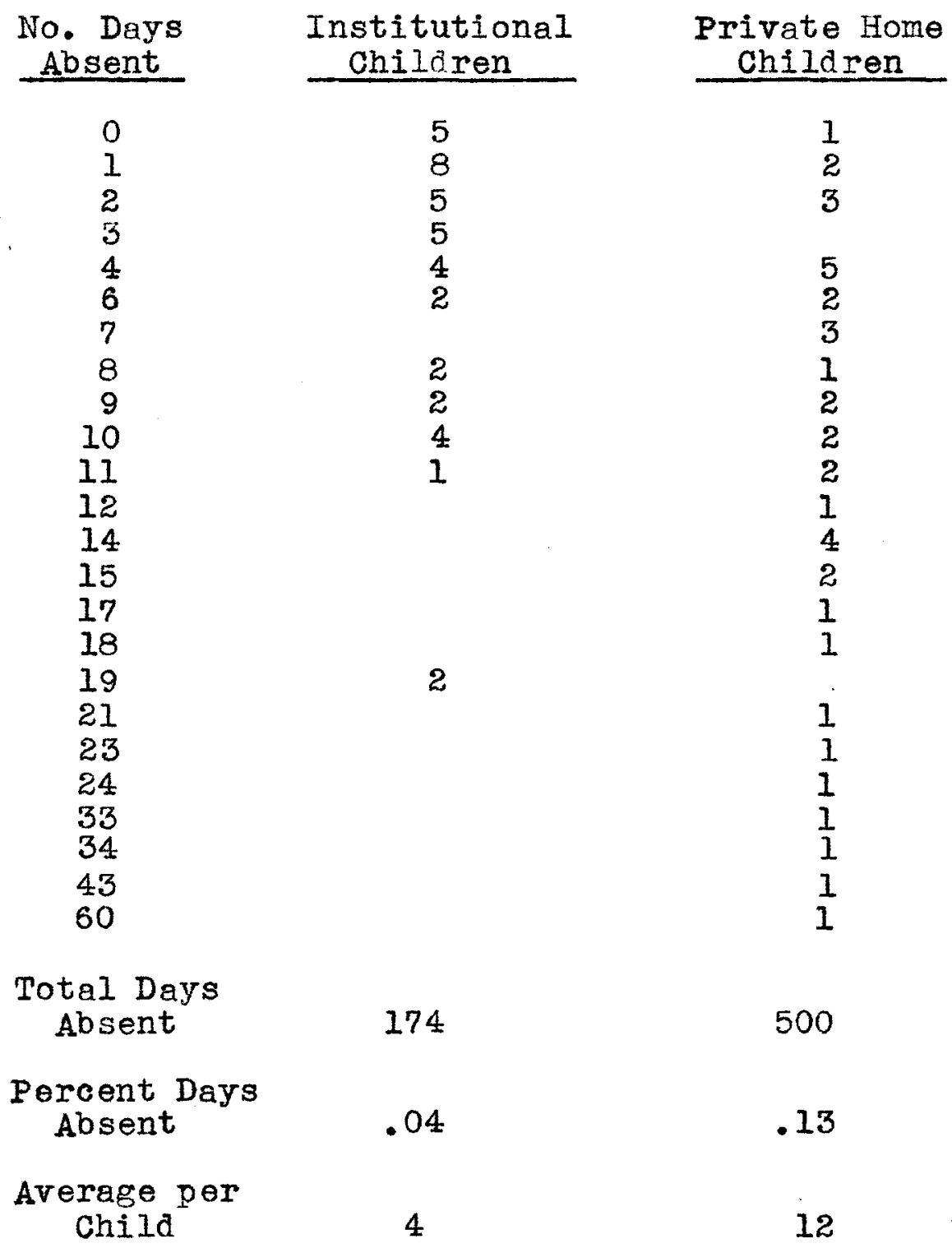


Five people from the institution had a perfect attendance record against one from the private homes during the period from September 9, 1943 to January 28, 1944. The 35 institutional pupils have a total of 174 days of absence with a membership of 3,760 days or an average 4 percent of absence. The 39 children from private homes have a record of 539 days absent and a membership of 3,748 days or an absence percentage of 13 plus.

Absence during the term was checked very carefully. Unless written excuses were brought to the teacher for each days' absence, the visiting teacher investigated the cases. There were eight cases of contagion in the orphanages; namely, measles and mumps, and two influenza cases. Three girls stayed home to' fumigate their hair of nits' which they had received from one of the other children of the class. Six days absence was due to three of the larger girls being kept home to help serve the dinner when the Board Members met at the Home. Four girls were unable to be present one konday morning because they sang at a country church out in the state at a Sunday night service. As it was quite late when they came home, they were too sleepy to attend school the following morning. Five children had upset stomachs after spending the week-end with friends who whed to see just how much they 
could eat. The other cases of absence were due to colds or stomach disorders which usually lasted a day or two.

The attendance from the Homes was usually very good. The children always knew who was absent as anyone feeling ill reported to the nurse before breakfast. All children are sent to the isolation ward, or hospital as they call it, at once. It is a happy day for all concerned when they are again able to appear in the dining room. They do not like to be kept at home because of illness for they have a more enjoyable time at school. The only incentive the orphanage offers for absence is a day of rest in bed. It is difficult to persuade a child to leave school and go home if he is really ill.

There were no cases of truancy from the institutions. This may be explained by the fact that the children were accompanied to school each morning by one of the matrons. It is possible the lack of truancy may be attributed to the attitude the institution has built up by stressing the importance of perfect school attendance. The orphan never questions his presence at school unless he is physically unable to attend. The children from the private homes present quite a different picture, only one person out of forty selected had a perfect attendance record. There were two cases of mimps. Two girls had to stay home with their younger sisters who had 
whooping cough; as their mother worked there was no one to care for the younger children. Four pupils were absent because of illness of their mothers, two becuase of appendicitis, six because of influenza. Several were out a day or two because of colds and minor illnesses. The following are sample excuses given by the children for their absence:

Excuses Given by the Children for Their Absences

1. Fathers leaving for Army or on furloughs.

2. Relatives on furlows.

3. Sister leaving for the Waves.

4. Stayed with baby while mother went shopping.

5. Had to go to court.

6. Helped move.

7. Picked cherries for mother and neighbors.

8. Didn't wake up in time.

9. Out late last night, too sleepy.

10. Went to Doctor or Dentist.

11. Went shopping.

12. Housekeeper didn't call me.

13. Fell out of tree - leg injured.

14. Father in hospital; went to see him.

15. Help mother do wash on Mondays.

16. Don't like to come to school on Fridays.

17. Raining; didn't have an umbrella.

18. Building is too cold.

19. Went to Grandmother's.

20. Cousin came to see me.

21. Sister was ill and I didn't want to come without her.

22. Just didn't feel well.

23. Didn't have my homework.

24. Too tired when I woke up.

25. Went to see Father in Navy hospital.

Each child after being absent was required to bring a note stateing the cause of his absence. When it was impossible to obtain a word from the home as to the child's absence, the visiting teacher made a call.

The reason for the absence, as stated in the parent's notes were tabulated and charted. Table IV shows the reasons for the absence among the children of the institutional and private home groups. 


\section{TABLE IV}

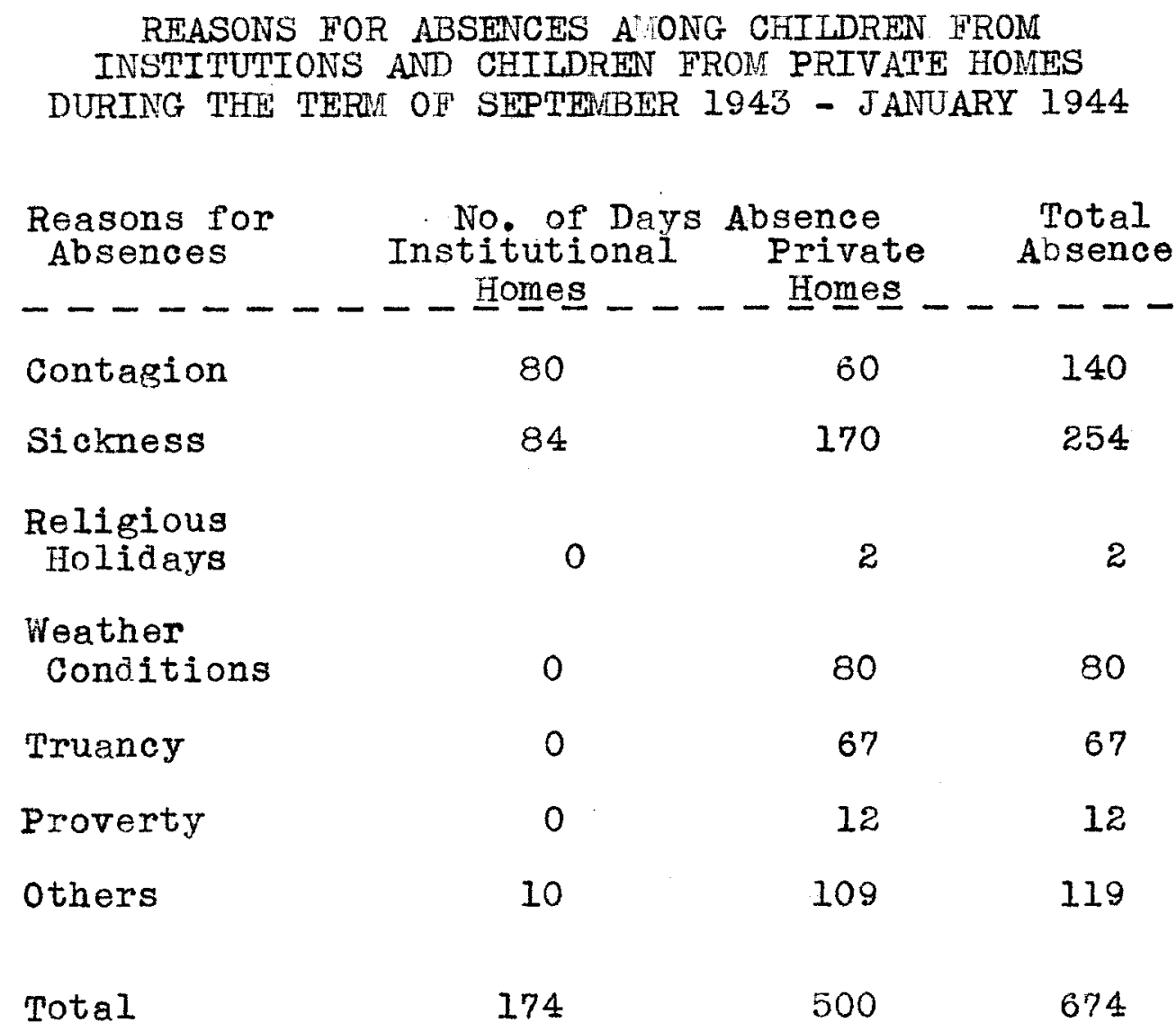

During the check on absences for the term there were found to be nine cases of truancy in the private home group. Four of the most quiet, unassuming and timid children just thought it would be fun to stay at home from school so they met at one of the little girls' houses. They soon found that they had not chosen their hideout wisely as the child's home adjoined the school yard. The truants could not so much as look out of the window for fear of being seen. One boy relates 
his experience:

'I sure got tired of playing Chinese
Checkers and Wonoply. We couldn't even
make any nolse for the woman upstairs
would have told Jeanette's mother. We
didn't have any food and were afraid to
go to the store for it. I'd rather go
to school any day. It's no fun cooped
up in two rooms all day and wonder if
you're going to get caught.

The following day all four mothers were notified of the truancy as one child's conscience troubled him and he told the teacher. The mothers were shocked; the teacher was too, for she did not think they had that much inltiative. This was the result of the parents being employed and leaving their children unsupervised.

Another case was of a boy, an only child, very neat and well dressed, of above average ability, who did not hesitate to let one know that he thought himself above the group. He could rarely see his mistakes and always offered some justification for his errors. He had few real friends among the children and openly showed his jealousy of people who had a higher scholastic record than ho.

Jimmy was absent only eight days out of ninety the school term preceding his father's joining the Army. When his father left he was literally lost for most of his after school hours were spent with his dad. He worried a great deal because his mother had to work. He said he prepared the meals 
and did most of the housework for he feared his mother might become ill because of overwork. He depended on his landlady to awaken him each morming for his mother went to work at five. In a short time tardiness developed and Jimmy preferred to remain at home rather than be late. When the visiting teacher called and found that he had been a truant several times he wept and promised that the offense would not be repeated. He said not to tell his teacher, that he was so sorry that he had not lived up to his mother's expectations and he hated to cause the visiting teacher so much trouble. She assured him it was no trouble at all, just the way she made her living. The next two months he evidently wished her - to earn her money for he was absent most of the time. He persuaded his mother to take him to Texas to see his father. Them later, his father was ill so he was absent ten days while he visited him. He said it was very difficult writing his father every day when so little happened of interest to tell him. Jimm's mother threatened to stop work so as to see that he came to school, punished him, and bought him a dog, but to no avail. He always became ill at eight-thirty, did not wake up or was so busy that he overlooked the time and hated to be tardy so often. As a last resort the mother took him from school in May and sent him to live with his grandmother. 
The third case was of a child who lived with his grandmother and uncle, his uncle being in the same classroom with him for two years. It seemed that Louis was always to be found among the trouble makers of the school. No matter what happened one could be sure that he was in on the offense or could tell you all about it. He hardly knew what it was to tell the truth. He started playing truant with some boys from a parochial school and continued even after the grandmother would bring him to his classroom. Finally the mother decided to take the child and move into another neighborhood in order that he could attend a different school which would give him new friends. She claimed the grandmother was too strict with him and the uncle and children of the school had an un esirable influence on him. When last heard of he was the ring leader in the new school situation and the principal said he was certainly no uplifting addition to her group.

Another truant was an overgrown, exceptionally thin, anemic looking boy. He had been a truancy problem throughout school and had repeated five terms of school work. He was definitely not interested and was bored to death while in the classroom as he could not do the work. The doctor had suggested that it would be wise for him to take several months off from school and stay in bed. He was often seen in town 
at night rambling down the street as lifeless as a puppet, with a cigarette dangling from his mouth. He could scarcely be blamed for sleeping the next day in class.

His mother had reached the point where she was not disturhed about his truancy. She could nothing about it. When told about his excessive smoking and truancy she replied, "I don't want James to be a sneak and smoke behind my back, so I buy him the cigarettes, but I have told him not to smoke at school. He is old enough now to know that he should go to school, and I do not have the time to see that he goes as I have to work."

Robinson states,

That truancy leads to other delinquency is based upon the theory that children who truant probably engage in anti-social activities. Equally plausible is the possibility that children who stay out of school do so not necessarily for mischief, but to indulge in activities which interest them much more than the rather formal, academic school curriculum. Some stay out with the connivance of their parents. If they were not, unfortunately, disobeying school regulations their activities might be considered quite harmless, perhaps even constructive. 1

It seems to be the opinion of teachers in our school

that a child is not truant if the parent knows that the child

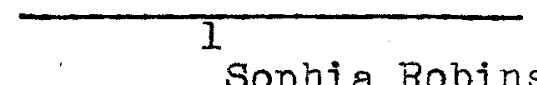

Sophia Robinson, Can Delinquency Be Measured? The Welfare Council of New York City, 1936, p.127. 
is staying away from school. He is not called a truant unless he is absent from school without the parent's permission. The teachers agree with Teagarten that truancy is often a problem between the school, parent, and the child. Often the parent is the truant rather than the child.

Truancy is primarily a problem between the school and the child; secondarily, between the school, the child and the parent; and thirdly, a problem to be referred to a juvenile court, or any other outside agency. The causes of truancy are many. A number of factors involved in tardiness may also be operative in producing truancy. Previous absences, justifiable or otherwise, which a child fears he can not make up, may cause continued staying away from school. The antagonism or indifference of a parent toward a school is another factor. 1

Tardiness is another problem which faces the school. Mothers going to work early, or working until late at night, then oversleeping, children cooking their own breakfasts, no clocks, or clocks out of order, depending on a landlady to call, are all factors which contribute toward making children tardy. There were 56 cases of tardiness during the term from the children of the private homes, as against 2 cases from the institutional group. One child did not pass morning inspection and was sent back for a second trial at washing. A girl had

1

Florence Teagarten, Child Psychology for the Professional Worker, p. 453 . 
wasted her time in the morning and had not completed her assigned task of dusting the hall. She was not allowed to come to school until it was finished.

\section{E Surmary}

1. Approximately one third of the enrollment of the Victor H. Engelhard School was made up of children from the Baptist and Christian Orphan's Homes.

2. Ninety-five percent of the children from private homes lived in rented dwellings and rooming houses in a central area of the c1ty. Thirty-eight percent of these families of this group of 40 children lived in one or two rooms.

3. Sixty-three percent of the 40 children from private homes lacked parental supervision since both parents held full time positions outside the home.

4. Sixty-three percent of the pupils from private homes earned money by working after school hours. The children with parents who worked had opportunities to develop resourcefulness, self relience and initiative by added responsibilities in caring for home and family in the absence of their parents.

5. Institutional children are deprived of the freedom and privilege enjoyed by the pupils from the private home group to participate in special school activities outside the regular school hours.

6. Conditions for home study were better in the institu- 
tional homes due to the fact that definite times and desirable places for study were provided.

7. Institutional pupils lived by a rigid schedule and the definite routine of activities were under constant supervision.

8. Medical and dental care in the institutions was superior to that in the private homes for the pupils were under the supervision of a nurse and had regular physical examinations.

9. The institutional children were more regular in attendance with only four percent of absence while the pupils of the private home group had 13 percent of ahsence. 
CHAPIIER IV

EDUCATIONAL FACTORS 


\section{CHAPTER IV}

\section{EDUCATIONAL FACTORS}

Do institutional children differ greatly from children in private homes in scholarship achievement in the sixth grade?

\section{A Intelligence Tests}

In an attempt to answer this question, the Kuhlman Anderson Inteligence Test was administered the first week in october, 1943 to all students of the sixtr A grades in the school to get an index of their native ability. of the 156 pupils tested forty were wards of institutions. These 40 children were used as the experimental group. Out of the remajning 116 pupils, 40 pupils from private homes, whose I.Q.' $\mathrm{s}$ matched as nearly as possible those of the experimental group, were set up as the control group. After these two groups had been selected the writer wished to know how the institutional group ranked with the 116 children from private homes in the intelligence scores. Table $V$ shows the frequency of the I.Q.'s of all $6 \mathrm{~A}$ children tested minus the forty institutional children. 
TABLE $V$

FREQUENCY TABLE OF THE I. Q. OF ALL THE CHILDREN IN THE SIXTH GRADE-IMINUS THE STUDENTS FROM THE INSTITUTIONS …ERROLLED IN A PUBLIC SCHOOL

\begin{tabular}{|c|c|c|c|c|c|}
\hline \multirow{2}{*}{$\frac{\text { Upper }}{\text { I. Q. }}$} & \multirow{2}{*}{$\begin{array}{l}\text { Quartile } \\
\begin{array}{l}\text { No.times } \\
\text { reported }\end{array}\end{array}$} & \multicolumn{2}{|c|}{ Inter-quartile } & \multirow{2}{*}{$\frac{\text { Lower }}{\text { I. Q. }}$} & \multirow{2}{*}{$\begin{array}{l}\text { Quartile } \\
\begin{array}{l}\text { No.times } \\
\text { reported }\end{array}\end{array}$} \\
\hline & & I. Q. & $\begin{array}{l}\text { No.times } \\
\text { reported }\end{array}$ & & \\
\hline 141 & 1 & 109 & 5 & 92 & 4 \\
\hline 127 & 1 & 108 & 1 & 90 & 3 \\
\hline 125 & 2 & 107 & 4 & 89 & 2 \\
\hline 123 & 1 & 106 & 2 & 88 & 5 \\
\hline 122 & 2 & 105 & 5 & 87 & 5 \\
\hline 121 & 1 & 104 & 5 & 84 & 2 \\
\hline 120 & 3 & 103 & 4 & 83 & 2 \\
\hline 119 & 2 & 102 & 4 & 82 & 2 \\
\hline 116 & 2 & 101 & 4 & 81 & 1 \\
\hline 115 & 1 & 100 & 5 & 75 & 1 \\
\hline 114 & 5 & 99 & 5 & 67 & 1 \\
\hline 113 & 3 & 98 & 2 & & \\
\hline 112 & 1 & 97 & 1 & & \\
\hline \multirow[t]{4}{*}{111} & 3 & 96 & 2 & & \\
\hline & & 95 & 5 & & \\
\hline & & 94 & 2 & & \\
\hline & & 93 & 2 & & \\
\hline
\end{tabular}


FREQUENCY TABLE OF THE I. Q. OF FORTY CHILDREN ENROLLED IN A PUBLIC SCHOOL WHO WERE MBMBERS OF AN INSTITUTIONAL HOME

\begin{tabular}{|c|c|c|c|c|c|}
\hline Upper & Quartile & Inter & -Quartile & Lower & Quartile \\
\hline I. Q. & $\begin{array}{l}\text { No.times } \\
\text { reported }\end{array}$ & I. Q. & $\begin{array}{l}\text { No.times } \\
\text { reported }\end{array}$ & I. Q. & $\begin{array}{l}\text { No.times } \\
\text { reported }\end{array}$ \\
\hline 119 & 1 & 106 & 4 & 94 & 1 \\
\hline 118 & 1 & 105 & 2 & 93 & 0 \\
\hline 117 & 0 & 104 & 3 & 92 & 2 \\
\hline 116 & 1 & 103 & 0 & 91 & 0 \\
\hline 115 & 1 & 102 & 1 & 90 & 1 \\
\hline 114 & 0 & 101 & 3 & 89 & 0 \\
\hline 113 & 0 & 100 & 1 & 88 & 1 \\
\hline 112 & 2 & 99 & 0 & 87 & 0 \\
\hline 111 & 0 & 98 & 2 & 86 & 0 \\
\hline 110 & 1 & 97 & 1 & 85 & 1 \\
\hline 109 & 1 & 96 & 3 & 84 & 1 \\
\hline \multirow[t]{3}{*}{108} & 2 & & & 83 & 1 \\
\hline & & & & 75 & 1 \\
\hline & & & & 74 & 1 \\
\hline
\end{tabular}

It was found that the upper quartile of the I. Q.' 's of these 116 pupils ranged from 141 to 111. This twenty-five per cent was in the "superior and high average group". Seventy-five percent of the group had I. 's below 110 . 
Table VI shows that the upper quartile of the I.Q'.S of the forty institutional children started much lower in the scale than the pupils from private homes. Their I. range was from 119, high average to 108 average. The lower twenty-five of the group was from 92 to 74 . There was a larger spread in the upper and lower quartiles of the pupils from the private homes. This was probably due to the fact that there were more cases in this group.

There were only three points difference in the median I. . of the institutional children, which was 104, and that of the 116 pupils from private homes which was 101. 


\section{TABIE VII}

INTELIIGENCE QUOTIENTS OF ONE HUNDRED SIXTEEN

PRIVATE HORE CHILDREN AND FORTY INSTITUTIONAL CHILDREN ETRROLIED IN A PUBLIC SCHOOL OCTOBER 1943

\begin{tabular}{|c|c|c|c|}
\hline & $\begin{array}{l}\text { Forty } \\
\text { Institutional } \\
\text { Children } \\
\end{array}$ & & $\begin{array}{c}\text { One } \\
\text { Hundred Sixteen } \\
\text { Private Home } \\
\text { Children }\end{array}$ \\
\hline Mean Scores & 105.25 & & 101.47 \\
\hline Range & $119-74$ & & $141-67$ \\
\hline Standard Deviation & 45.7 & & 47 . \\
\hline $\begin{array}{l}\text { Standard Deviation } \\
\text { of the Mean }\end{array}$ & 7.23 & & 4.36 \\
\hline $\begin{array}{c}\text { Difference of the } \\
\text { Nean }\end{array}$ & & 3.78 & \\
\hline $\begin{array}{l}\text { Standard Deviation } \\
\text { of the Difference } \\
\text { of the Mean }\end{array}$ & & 4.24 & \\
\hline Critical Ratio & & .88 & \\
\hline Significant & & No & \\
\hline
\end{tabular}

The data indicated that there was no wignificant difference between the intelligence quotients of one hundred sixteen children from private homes enrolled in the sixth grade and the forty institutional children. 
Table VII showed that the critical ratio between the I. Q.' 's of the two groups was .83. A difference is considered significant statistically of the critical ratio is 3.00 or more. Statistically, then, there was no significant difference between the 110 children from the private homes and the 40 institutional children in the intelligence quotient scores. The remainder of this thesis will deal with the experimental group, forty children from the institution, and the control group, 40 children from private homes. 


\section{TABLE VIII}

A COMPARISON OF THE CONTROL GROUP AND EXPERIMHINAL GROUP BASED ON THE INTELLIGENCE QTJOTIENTS

\begin{tabular}{|c|c|c|c|c|c|}
\hline $\begin{array}{l}\text { Number } \\
\text { of } \\
\text { Matched } \\
\text { Cases }\end{array}$ & $\begin{array}{c}\text { I. Q.'s } \\
\text { of } \\
\text { Institution } \\
\text { Children }\end{array}$ & $\begin{array}{l}\text { I. G.'s } \\
\text { of } \\
\text { Private } \\
\text { Home } \\
\text { Children }\end{array}$ & $\begin{array}{l}\text { Number } \\
\text { of } \\
\text { Matched } \\
\text { Cases }\end{array}$ & $\begin{array}{c}\text { I. } Q^{\prime} \mathrm{s} \\
\text { of } \\
\text { Institution } \\
\text { Children }\end{array}$ & $\begin{array}{c}\text { I. Q.'s } \\
\text { of } \\
\text { Private } \\
\text { Home } \\
\text { Children } \\
\end{array}$ \\
\hline 1 & 74 & 82 & 21 & 104 & 104 \\
\hline 2 & 75 & 82 & 22 & 104 & 104 \\
\hline 3 & 83 & 85 & 23 & 105 & 105 \\
\hline 4 & 84 & 88 & 24 & 105 & 105 \\
\hline 5 & 85 & 88 & 25 & 105 & 106 \\
\hline 6 & 88 & 88 & 26 & 106 & 106 \\
\hline 7 & 90 & 89 & 27 & 106 & 106 \\
\hline 8 & 92 & 95 & 28 & 106 & 106 \\
\hline 9 & 92 & 95 & 29 & 106 & 106 \\
\hline 10 & 94 & 95 & 30 & 106 & 108 \\
\hline 11 & 96 & 96 & 31 & 108 & 108 \\
\hline 12 & 96 & 96 & 32 & 109 & 109 \\
\hline 13 & 96 & 96 & 33 & 109 & 109 \\
\hline 14 & 97 & 98 & 34 & 110 & 111 \\
\hline 15 & 100 & 98 & 35 & 112 & 113 \\
\hline 16 & 101 & 101 & 36 & 112 & 113 \\
\hline 17 & 101 & 101 & 37 & 115 & 114 \\
\hline 18 & 101 & 102 & 38 & 116 & 114 \\
\hline 19 & 102 & 104 & 39 & 118 & 120 \\
\hline 20 & 104 & 104 & 40 & 119 & 121 \\
\hline
\end{tabular}


Table VIII shows how nearly these two groups were natched on the basis of I.Q.'s. Case I from the institutional group was paired with case 1 from the private home group. The I. b.'s were paired identically in as many cases as was possible. The - percentage distribution of the cases is shown in Pable IX.

\section{TABLE IX}

PERCENTAGE DISTRIBUTION OF INTELLIGETCE GUOTIENTS OF INSTITUTIONAI CHILDREN AND CHIIDDEN FROM PRIVATE HOMES

Classification I. Q. Institutional Private Home

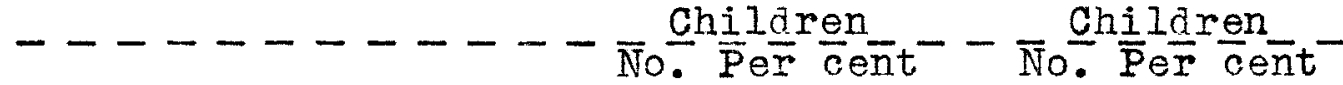
nf of Cases of of Cases

\begin{tabular}{|c|c|c|c|c|c|}
\hline Superior & $120-129$ & & & 2 & .05 \\
\hline High Average & $110-119$ & 7 &, 175 & 6 & .150 \\
\hline Normal & $100-109$ & 18 & .450 & 17 & .425 \\
\hline Average & $90-99$ & 8 & .200 & 8 & .200 \\
\hline Low Average & $80-89$ & $\mathrm{~s}$ & .125 & 7 & .175 \\
\hline $\begin{array}{l}\text { Bord } \in \text { rline } \\
\text { Defective }\end{array}$ & $70-79$ & 2 & .050 & & \\
\hline
\end{tabular}

The children were classified by the I.Q.'S into the groups of Superior, High Average, Average, Low Average or Borderline Defective.

Since the two groups of forty pupils wach had been matched by intellifence quotients it was interesting to note the comparison of their chronological ages. 
TABLE $\underline{X}$

CHRONOLOGICAL AGES OF PUPILS

\begin{tabular}{|c|c|c|c|}
\hline \multicolumn{2}{|c|}{ Forty from } & \multicolumn{2}{|c|}{ Forty from } \\
\hline $\begin{array}{l}\text { Inst: } \\
\text { Years }\end{array}$ & itutions & Priv & $\begin{array}{l}\text { te Homes } \\
\text { Months }\end{array}$ \\
\hline Years & $-{ }_{\text {III }}$ II & - - $_{14}$ & $-2^{-113}$ \\
\hline 14 & 3 & 14 & 0 \\
\hline 14 & 1 & 13 & 7 \\
\hline 14 & $\bar{I}$ & 13 & 6 \\
\hline 13 & 5 & 13 & 3 \\
\hline 13 & 4 & 13 & 3 \\
\hline 13 & 1 & 13 & 3 \\
\hline 13 & 1 & 12 & $1 I$ \\
\hline 13 & 1 & 12 & 9 \\
\hline 13 & 0 & 12 & 9 \\
\hline 13 & 0 & 12 & 8 \\
\hline 13 & 0 & 12 & 7 \\
\hline 12 & 11 & 12 & $\eta$ \\
\hline 12 & 11 & 12 & 7 \\
\hline 12 & II & 12 & 6 \\
\hline 12 & 10 & 12 & 5 \\
\hline 12 & 10 & 12 & 5 \\
\hline 12 & 10 & 12 & 4 \\
\hline 12 & 9 & 12 & 4 \\
\hline 12 & 8 & 12 & 4 \\
\hline 12 & 8 & 12 & 3 \\
\hline 12 & 6 & 12 & 2 \\
\hline 12 & 6 & 12 & 2 \\
\hline 12 & 5 & 12 & 2 \\
\hline 12 & 4 & 12 & 2 \\
\hline 12 & 2 & 12 & 2 \\
\hline 12 & 2 & 12 & 2 \\
\hline 12 & 2 & 12 & 1 \\
\hline 12 & 2 & 12 & 1 \\
\hline 12 & 1 & 12 & 0 \\
\hline 12 & 1 & 12 & 0 \\
\hline 12 & 0 & 11 & 9 \\
\hline 11 & 11 & 11 & 9 \\
\hline 11 & 11 & 11 & 8 \\
\hline 11 & 7 & 11 & 5 \\
\hline 11 & 7 & 11 & 3 \\
\hline 11 & 4 & 11 & 3 \\
\hline 11 & 3 & 11 & 2 \\
\hline II & 2 & II & 2 \\
\hline 10 & 9 & 11 & 1 \\
\hline
\end{tabular}

Average Age 12

7

124

Median Age 12

8

12

5 
Table $X$ shows the chronological ages of the groups. The median age of the institutional pupils was 12 years, 8 months, while the median age of the pupils from the private home group was 12 years, 5 months. There was the slight difference of three months in the average age of the two groups, yet the range in ages showed a different picture. The age span of the institutional group was from 10 years, 9 months to 14 years, 11 months. The ages range in the private home group from 11 years, 1 month to 14 years, 2 months, pr three years and ore month's spread. There is a difference of one year, one month in the span of the two groups. While the chronological ages were not considered as a basis for grouping, yet the ages were practically the same. Permanency of residence affects the shoolarship and grade placement of children. In order to learn which group had to make the greater number of school adjustments and the effect of the changes on thie chronological age and grade placement, the average number of schools attended per child was determined by studying the accumulative records of the Louisville Public Schools. The number of changes in schools made by each group is recorded in Table XI, which follows: 


\section{TABLP XI}

NUMABER OF SCHOOLS EACII CHILD ATTENDED DURIING SIX YEARS OF BLEMENTARY SCIOOL

$$
\begin{aligned}
& \text { No. of Schools Average Number } \\
& \text { Attended Schools Attended }
\end{aligned}
$$

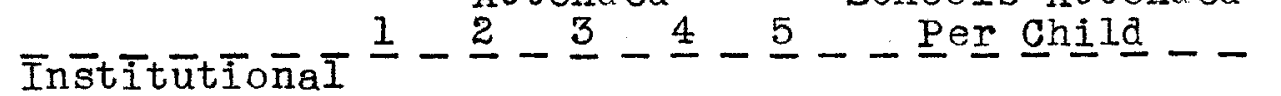

$$
\begin{aligned}
& \begin{array}{llllll}
\text { Children } & 8 & 22 & 7 & 3 & 2.12
\end{array} \\
& \text { Private Home } \\
& \begin{array}{lllllll}
\text { Chilären } & 10 & 13 & 12 & 2 & 3 & 2.37
\end{array}
\end{aligned}
$$

The total number of school changes made by the institutional group of 40 children was 35 , or an average of 2.12 , while the total number made by the children from private homes was 95 for the 40 children, an average of 2.37. Table XII shows this was not a significant difference between the two groups. These results correlate with the results of the study of the chronological age of the two groups. Table $X$ showed the chronological age of the institutional children to be 12.5 while the chronological age of the children from private homes was 12.4. This, also, showed no appreciable difference between the two groups. 


\section{TABLE XII}

NUMBER OF SCHOOLS EACH CHILD ATPENDED

DURING THE SIX YEARS OF ELEMIENTARY SCHOOL

\begin{tabular}{|c|c|c|}
\hline & $\begin{array}{l}\text { Institutional } \\
\text { Children }\end{array}$ & $\begin{array}{l}\text { Private Home } \\
\text { Children }\end{array}$ \\
\hline Mean Scores & 2.13 & 3.23 \\
\hline Range & $1-4$ & $1-5$ \\
\hline Standard Deviation & 3.11 & 2.68 \\
\hline $\begin{array}{l}\text { Standard Deviation } \\
\text { of the Mean }\end{array}$ & 1.93 & 6.39 \\
\hline $\begin{array}{c}\text { Differences between } \\
\text { Means }\end{array}$ & & \\
\hline $\begin{array}{l}\text { Standard Deviation } \\
\text { of Difference }\end{array}$ & & \\
\hline Critical Ratio & & \\
\hline
\end{tabular}

The data indicated that there was no significant difference between hte number of schools attended by the private home group and the children from institutions. 
The writer noticed that several children were rather retarded in their grade achievement for thier chronological age. This may be explained when Table XIII is examined.

\section{$\underline{\text { TABLE }}$ III}

NUMBER OF SCHOOL TERWIS RPPEATED BY PUPILS FROA INSTITUTIONS AND FROM PRIVATE HOMES

No. of terms repeated No. Pupils No. Terms $-\underline{1}-\underline{2}-\underline{3}-\underline{4}-\underline{5}-$ Repeating_ Repeated

No. Institutional

Children

No. Pupils from

private homes $\begin{array}{lllll}4 & 3 & 4 & 1 & 0\end{array}$

12

$\begin{array}{lllll}3 & 3 & 0 & 2 & 1\end{array}$

9

22

Twelve children from the institution had repeated a total of 27 terms and nine from private homes had repeated 22 terms during their elementary school work. This accounts for the span in the age group of four years and two months in the sixth grade.

As there was so close a relation between the $I .6_{0}$ 's and the chronological ages it would naturally follow that the mental ages of the two groups would be very similar. 


\section{GRAPH II}

COMPARISON OF THE MENTAL AGES IN PERCENTAGES

OF A GROUP OF 40 INSTITUTIONAL CHILDREN

WITH A GROUP OF 40 CHILDRFN FROM PRIVATE HOMES

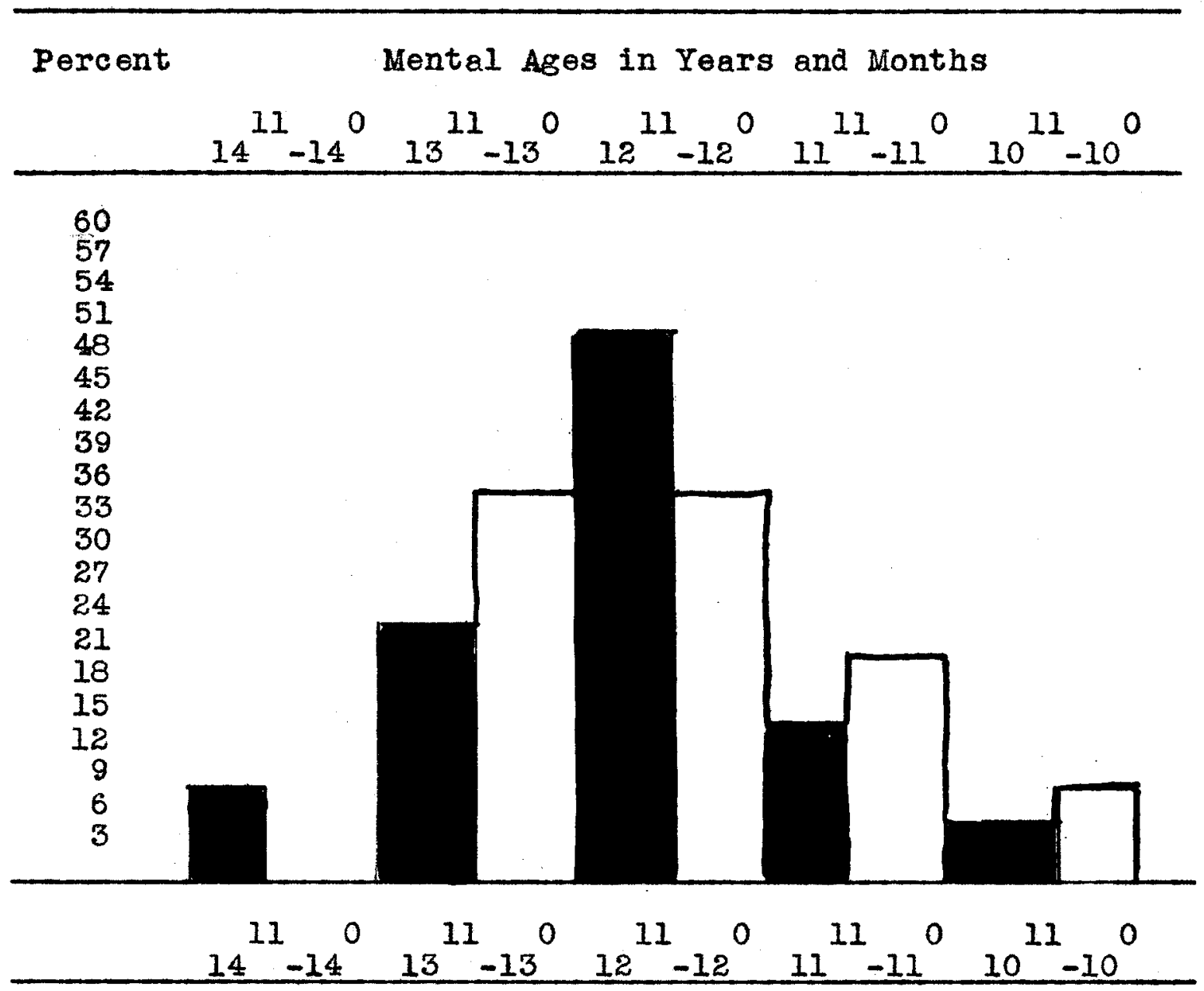

Percentage of children from Institutions

Percentage of children from Private Homes 
Graph II shows the comparison of the mental age span of the two groups of children. The mental age span of the institutional group was from 14 years, 6 months to 10 years, There was a difference of 4 years, 6 months in mental ages in this group. In the private home group the mental ages range from 13 years, 10 months to 10 years, 4 months. This was only one year's difference in the span of mental ages of the two groups. The median age level for the institutional children was 12 years, 8 months against 12 years, 5 months for the group from the private homes. There was only an average of three month's difference in the mental age of the group as would be expected since the I.Q.' $s$ and chronological ages were nearly identical.

\section{B Achievement Tests}

During the month of october all sixth grade children in Louisville were given the Progress Achievement Test, Elementary Battery, Form B. All Achievement tests have as their puroose the measurement of the results of teaching. This test presupposes instruction in definite fields and is a diagnostic survey group test in fundamental skills designed to measure the extent of pupil mastery in reading vocbulary, reading comprehension, arithmetic reasoning and fundamentals, and language. The Form B of the Progressive Achievement Test was de- 
ministered in october, and later followed by Form $\mathrm{c}$, to the forty children from the institution and the forty children from the private home group in order to make a comparative study of the progress in achievement made during the term.

The same method in the discussion of the results of the test in the different subjects will be used. The Experimental Group was paired as to I.Q.'s with the Control Group. Case I, a child from the institution had the same I. Q. as Case 1 , a child from the private home group.

Initial and final sroup data, i.e. data secured from October, 1943 to January, 1944 are given in Tables XV to XXVII inclusive. The tables show the improvement, in grade placement made in reading, arithmetic and language.

The comparability of the improvement of the institutional group and the private home group was also judged by the means, standard deviations and critical ratios. The means were calculated by regular procedures. Stanỏard deviations were de-

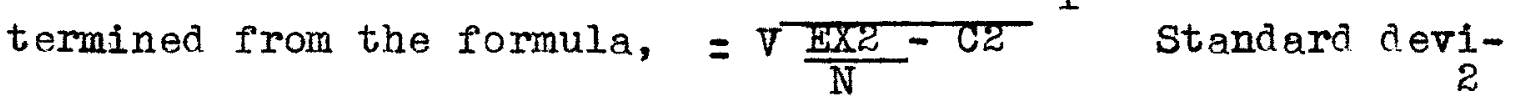
ations of the means were calculated from the $=V N-I$ and the standard deviations of the differences between the mean were calculated from formula $A-B V \frac{2-{ }_{A}}{2}$ critical ratios

\footnotetext{
J.W.Dunlap and A.I.Kurtz, Handbook of Statistical $\frac{\text { Nomogrpahs, Tables and Formulas. }}{2}$.

3 Ibid., Formula 8.

Ibid., Formula 154.
} 
are quotients of the differences between the mean divided by the standard deviation of these differences. A difference is considered significant statistically if the critical ratio is 3.00 or more - the accepted procedure in the interpretation of educational data.

Graph II through VI give the frequency of improvement made by the individuals of the two groups.

The results of these three types of charts and graphs will be discussed with the subjects tested on the Progressive Achievement Battery, Form B. and C.

The results of the Vocabulary Reading Test are found on Table XIV. 


\section{TABLE XIV}

\section{RESULTS OF THE PROGRESSIVE ACHIEVEUINT TEST IN READING VOCABULARY IN GRADE PIACEMINTS ADNINISTERED \\ OCTOBER 1943 AND JANUARY 1944 TO FORPY INSTITUTIONAL CHILDREN AND FORTY CHILDREN FROM PRIVATE HOMES}

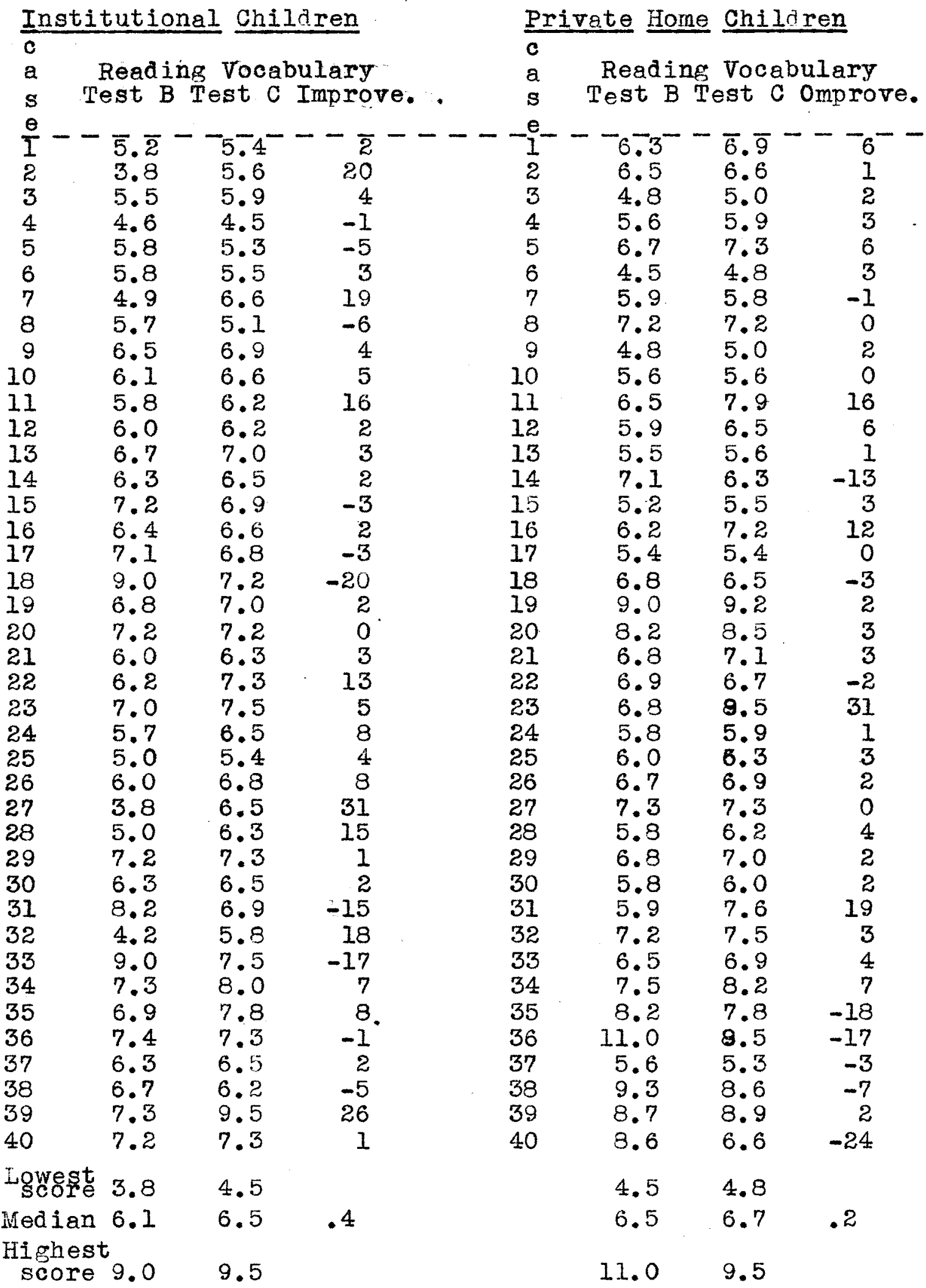


In this Test Form B, the institutional children had a range of 3.8 to 9.0 in grade placement. The median for the group was 6.1. In Form C, administered in January, the range in grade placement in the Reading Vocabulary Test was 4.5 to 9.5, the mesian being 6.5. This was an average improvement of four months during the term for the institutional group. See Table XXIX.

The private home group had a range of 4.5 to 11.0 on Test B. On Test $C$, the range was 4.8 to 9.5 in Reading Vocabulary. The grade placement median was 6.5 on Test $B$ and 6.7 on Test $C$, an improvement of two months, Table XXIX. The greatest improvement in Reading Vocabualry was 2.7 , made by a pupil from the institutional group.

The private home children had a higher grade placement score on the initial Test B 6.5 to 6.1 than the institutional children while the orphanage group made 4 month's improvement contrasted to 2 months made by the private home group.

Table XVII shows the improvement in Reading Comprehension. On the first test, the institutional group had a span of 3.9 grade, or from 4.7 to 9.0 in Comprehension, with a median grade of 6.6 on the second test the median grade was 6.9, which was an improvement of 3 months. The chiloren from the private homes improved 6 months. Their range was 5.2 to 8.8 in Test B, and from 5,4 to 9.5 on Test C. The child which made the greatest improvement 2.6 was from the private home group. 


\section{$\underline{T A B L E} \quad \underline{X V}$}

STATISTICAL SINGIFICANCE OF THE DIFFERENTCE BETWEEN FORTY INSTITUTIONAL CHILDREN AND FORTY CHILDREN FROM PRIVATE HOMES ON THE READING VOCABULART OF THE PROGRESSIVE ACHIEVWMENT TEST FORM B ADWINISTERED OCTOBER 1943

\begin{tabular}{|c|c|c|c|}
\hline & $\begin{array}{l}\text { Institutional } \\
\text { Children }\end{array}$ & & $\begin{array}{l}\text { Private Hone } \\
\text { Children }\end{array}$ \\
\hline Mean Scores & 5.03 & & 6.70 \\
\hline Range & $3.8-9.0$ & & $4.5-11.0$ \\
\hline Standard Deviation & 4.11 & & 4.06 \\
\hline $\begin{array}{l}\text { Standard Deviation } \\
\text { of Mean }\end{array}$ & .65 & & .64 \\
\hline $\begin{array}{c}\text { Difference between } \\
\text { Means }\end{array}$ & & .67 & \\
\hline $\begin{array}{l}\text { Standard Deviation } \\
\text { of the Difference } \\
\text { between Means }\end{array}$ & & .64 & \\
\hline Critical Ratio & & 1.04 & \\
\hline Significant & & No & \\
\hline
\end{tabular}

The above computation shows that there is a slight difference in the scores but not enough to be significant. 


\section{$\underline{\text { TABLE }} \underline{\text { XVI }}$}

STATISTICAL SIGNIPICANCE OF THE DIFFERENCE BETWEHN FORTY INSTITUTIONAI CHILDREN AND FORTY CHIIDREN FROM PRIVATE HOMES ON THE READING VOCABULARY OF THE PROGRESSIVE ACHIEVERENT TUST FORM C ADNINISTERED JANUARY 1944

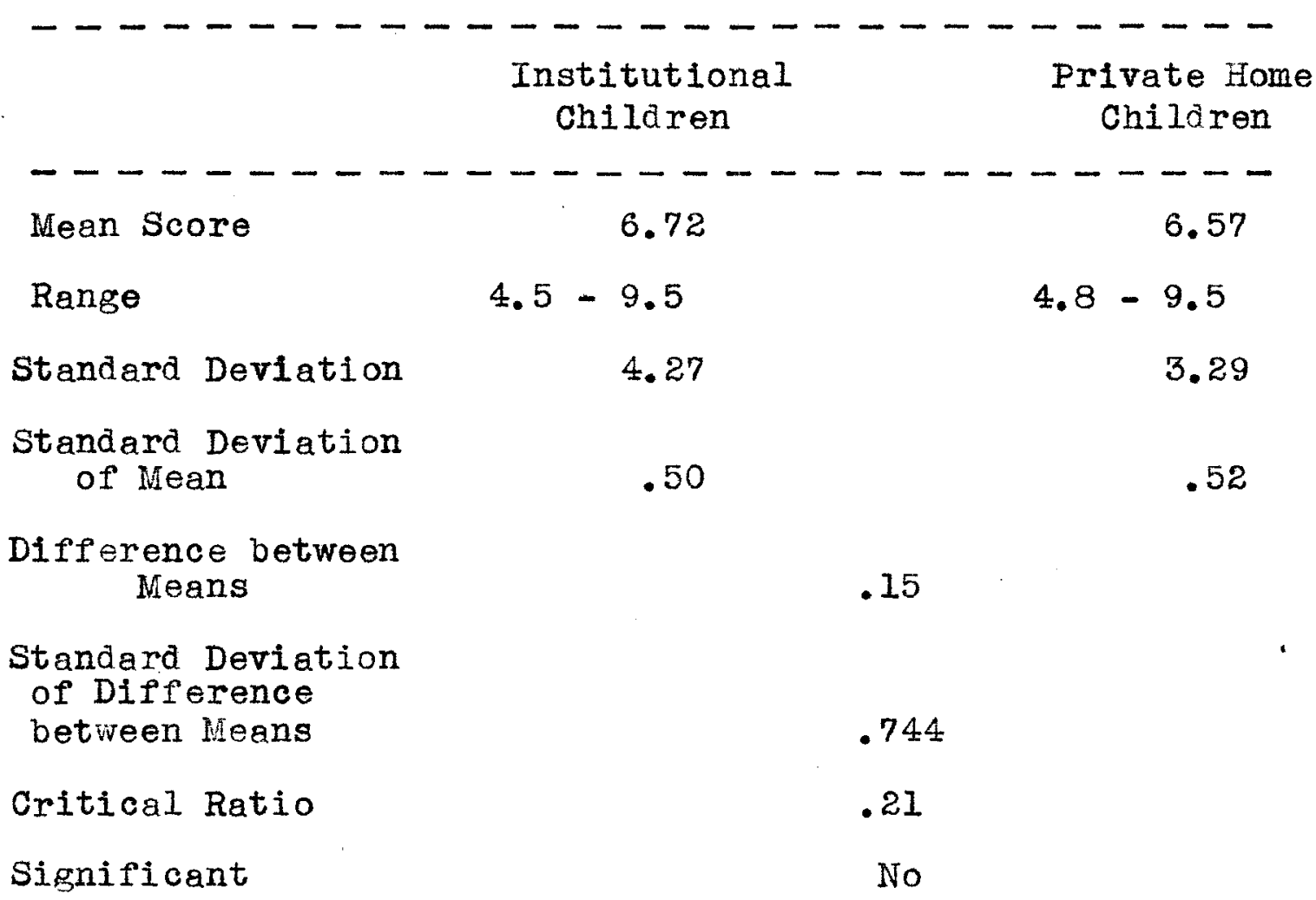

These data indicated tha there was no significant difference between the mean reading vocabulary score of the institutional group and the private home group. 


\section{$\underline{\text { GRAPH III }}$}

MONTHS IMPROVEMTENT IN GRADT PLACHMENT IN READING VOCABULARY OF THE PROGRESSIVE ACHIEVEMVINT TEST ADMINISTERED TO FORTY INSTITUTIONAL CHILDREN AND FORTY CHIIDREN FROM PRIVATE HOMES

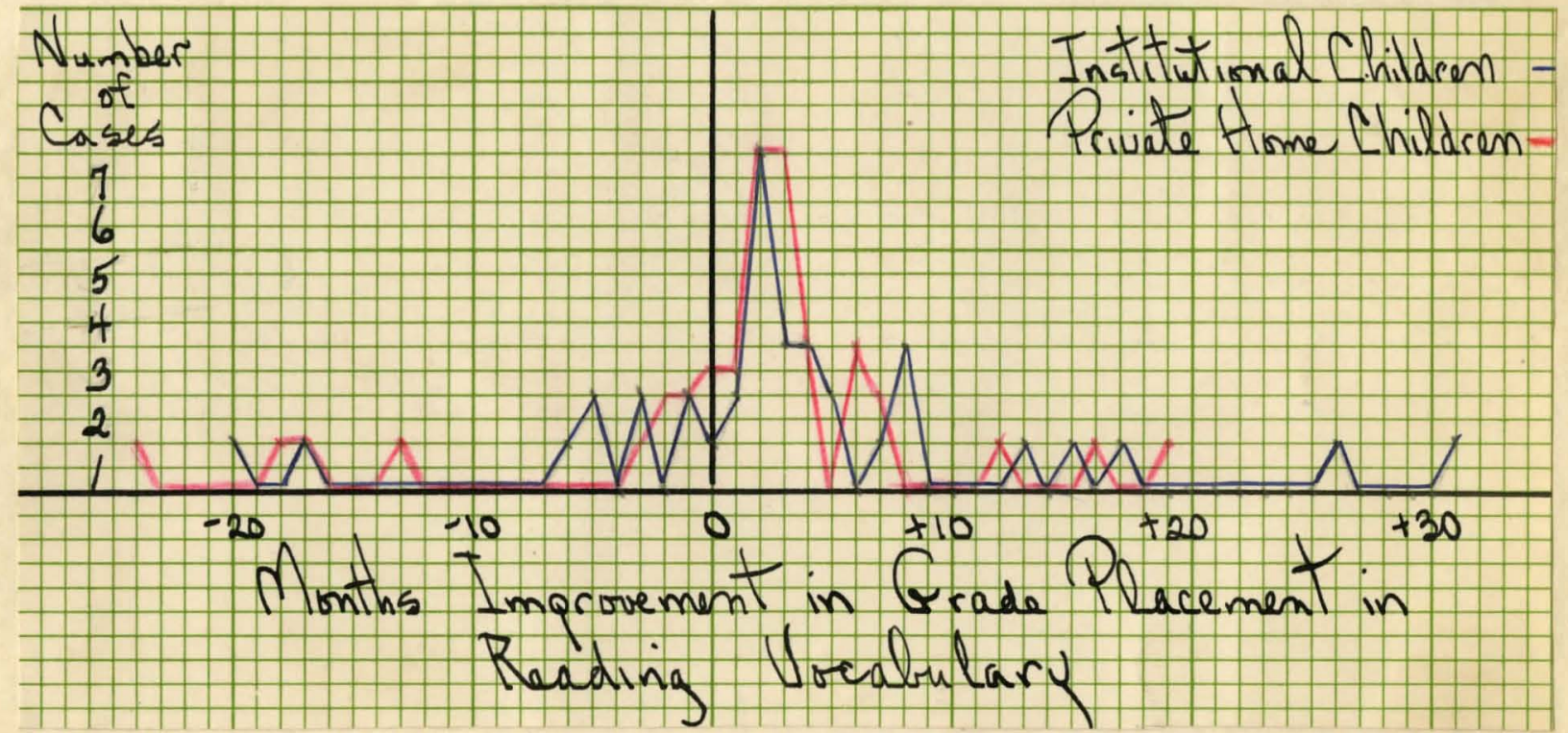

Twelve ohildren from the institution gained over $5 \mathrm{~m}$ months in grade placement in Reading Vocabulary. Seven children from the private home group gained 5 months in Reading Vocabulary during the term.

Six pupils from the institution lost over 3 months in progress against 7 from the private home group. 
TABLE XVII

RESULTS OF THE PROGRESSIVE ACHIEVEMENT TEST IN READING COMPRBHENSTON IN GRADE PLAC BMENT ADMINISTERED OCTOBER 1943 AND JANUARY 1944 TO FORTY INSTITUTIONAL CHILDREN AND FORTY CHIIDREN FROM PRIVATE HOMES

Institutional Children

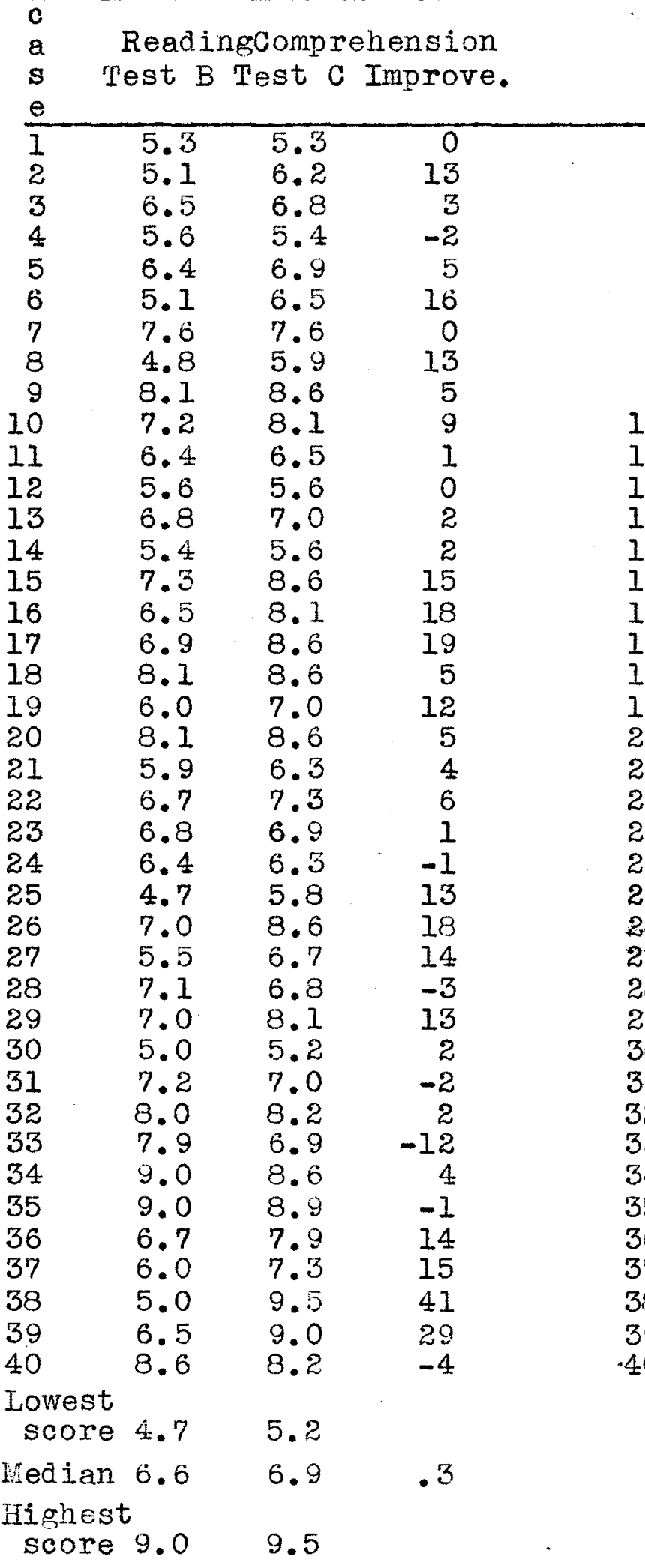

Private Home Children

Reading Comprehension Test B Test C Improve.

\begin{tabular}{llll} 
e & & & \\
\hline & 8.0 & 8.1 & 1 \\
3 & 6.0 & 6.4 & 4 \\
4 & 5.2 & 5.8 & 6 \\
5 & 5.9 & 6.3 & 4 \\
6 & 8.1 & 8.5 & 4 \\
7 & 5.5 & 5.8 & 3 \\
8 & 6.0 & 6.9 & 9
\end{tabular}

$8 \quad 6.5 \quad 7.6 \quad 13$

9

10

11

12

13

14

15

16

17

18

19

20

21

22

23

24

25

26

27

28

29

30

31

32

33

34

35

36

37

38

39

40
5.3

5.9

5.5

6.2

6.8

6.3

5.9

7.3

5.9

7.8

5.3

7.5

7.2

6.2

7.2

6.5

5.4

7.2

6.7

6.1

6.5

6.2

6.4

6.3

5.5

8.0

7.0

8.0

6.9

7.9

5.9

7.6

3.8

6.9

$$
8.1
$$

6.4

6.4

7.0

6.4

7.3

5.4

7.6

7.5

B. 5

7.6

7.1

7.9

7.5

6.9

6.7

7.6

0.7

7.0

6.8

6.0

8.3

7.5

8.5

6.7

8.6

6.5

8.6

8.9

9.5

5.2

5.4

6.5

7.1

8.8

9.5 
TABLE XVIII

STATISTICAL SIGNIFIOANCE OF THE DIFFERENCE BETHEEN FORTY INSTITUTIONAL CHILDREN AND FORTY CHILDREN FROM PRIVATE HONES ON THE RFADING CONIPRBHENSION OF THE PROGRESSIVE ACHIEVEIENT TEST FORM B ADIINISTERED OCTOBER 1943

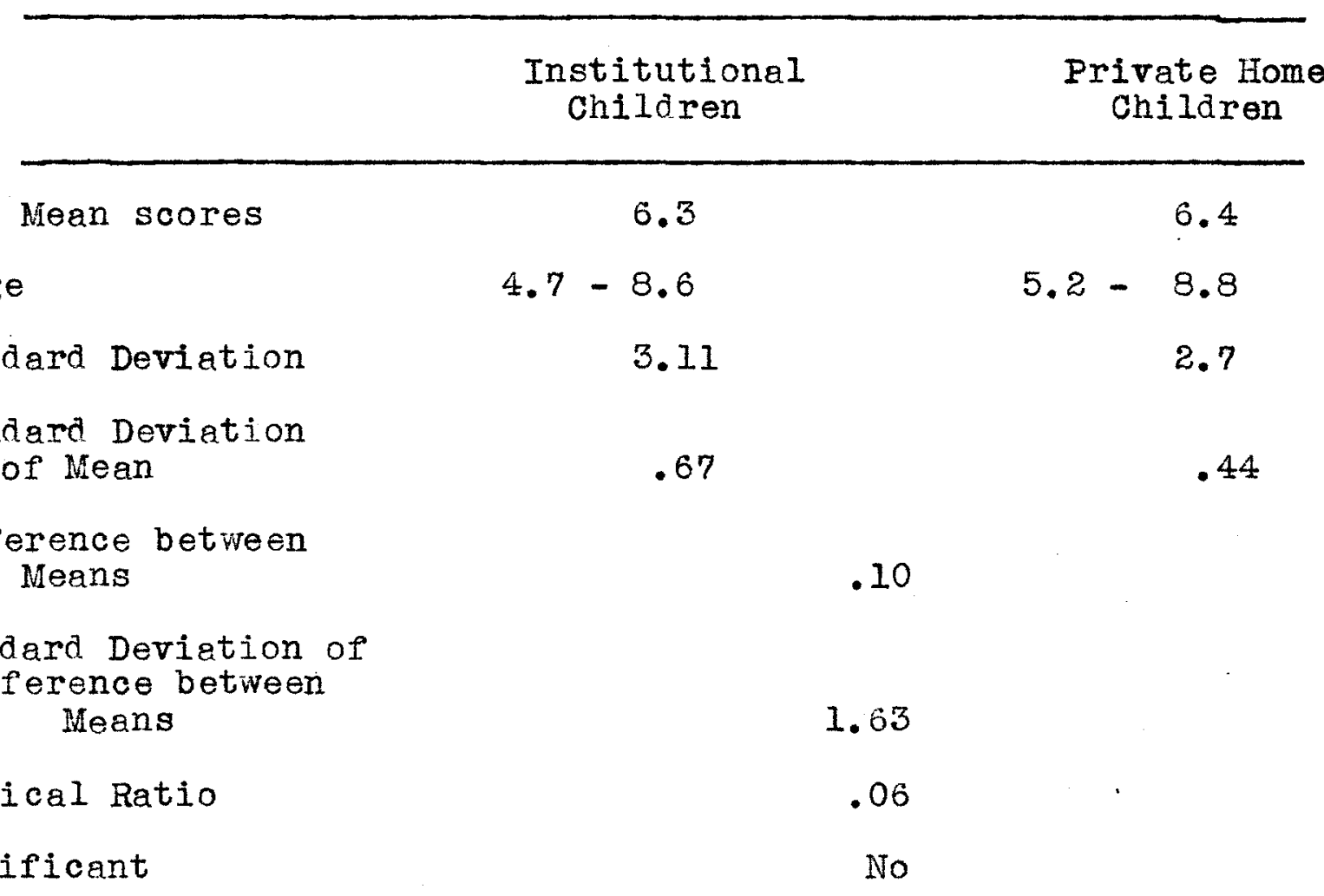

The data showed that the mean reading comprehension scores of the children from the institutional group and the children of the private home group were notsignificantly different. 
In the Reading scores it was found that the institutional children made seven month's improvement - the greatest progress was made in Reading Vocabulary. The Grade Placement Frequency Graph shows this. The group of private home children made 8 months improvement with their greatest gain being in Reading Comprehension. The greater improvement in the comprehension may be due to the fact that the private home group have more freedom in their environment. The children used the library, had access to newspapers, and magazines. There was an interest in current events and recreational reading. All these activities lead to improvement of comprehension in reading.

The children from the private home group made an improvement of 4 months in grade placement in Langaage during the term. The median for Test $B$ was 7.0 , and Test $c, 7.4$, see Table XXX. The span in grade placement for Test $B$ was 4.7 to 8.9 .

The institutional group only made a progress of 2 months in Language. On initial Test $B$ the median was 6.8 and Test $C$ 7.0. The lowest score on Test $B$ was 3.9 and the highest 9.0 . 


\section{$\underline{\text { TABLE }} \underline{\underline{X I X}}$}

STATISTICAI SIGNIFICANCE OF IHE DIFFERENCE BETWEN FORTY INSTITUIIONAL CHILDREN AIND FORTY CHILDREN FROR PRIVATE IHOMES ON THE RTADING COMPRETENSION OF' THE PROGRESSIVE ACHIEVEMENT TEST FORM C ADNINISTERED JANUARY 1944

\begin{tabular}{|c|c|c|c|}
\hline & $\begin{array}{l}\text { Institutional } \\
\text { Children }\end{array}$ & & $\begin{array}{l}\text { Private Home } \\
\text { Children }\end{array}$ \\
\hline Mean Scores & 6.77 & & 6.80 \\
\hline Range & $5.2-9.0$ & & $5.4-9.5$ \\
\hline Standard Deviation & 4.73 & & 3.53 \\
\hline $\begin{array}{l}\text { Standard Deviation } \\
\text { of Mean }\end{array}$ & .75 & & \\
\hline $\begin{array}{l}\text { Difference between } \\
\text { Means }\end{array}$ & & .03 & - \\
\hline $\begin{array}{l}\text { Standard Deviation } \\
\text { of Difference } \\
\text { between Means }\end{array}$ & & 3.00 & \\
\hline Critical Ratio & & .01 & \\
\hline Significant & & No & \\
\hline
\end{tabular}

These data showed that the mean reading comprehension scores of the institutional group and the private home group were not significantly different. 
GRAPH IV

IKONTHS IMPROVEMEINT IN GRADE PLACHMHNT IN READING COMPREHEIVION OF THE PROGRESSIVE ACHIEVEMENT TEST ADMINISTERED TO FORTY INSTITUTIONAL CHILDREN AIND FORTY CHILDREN FAOM PRIVATE HOMES

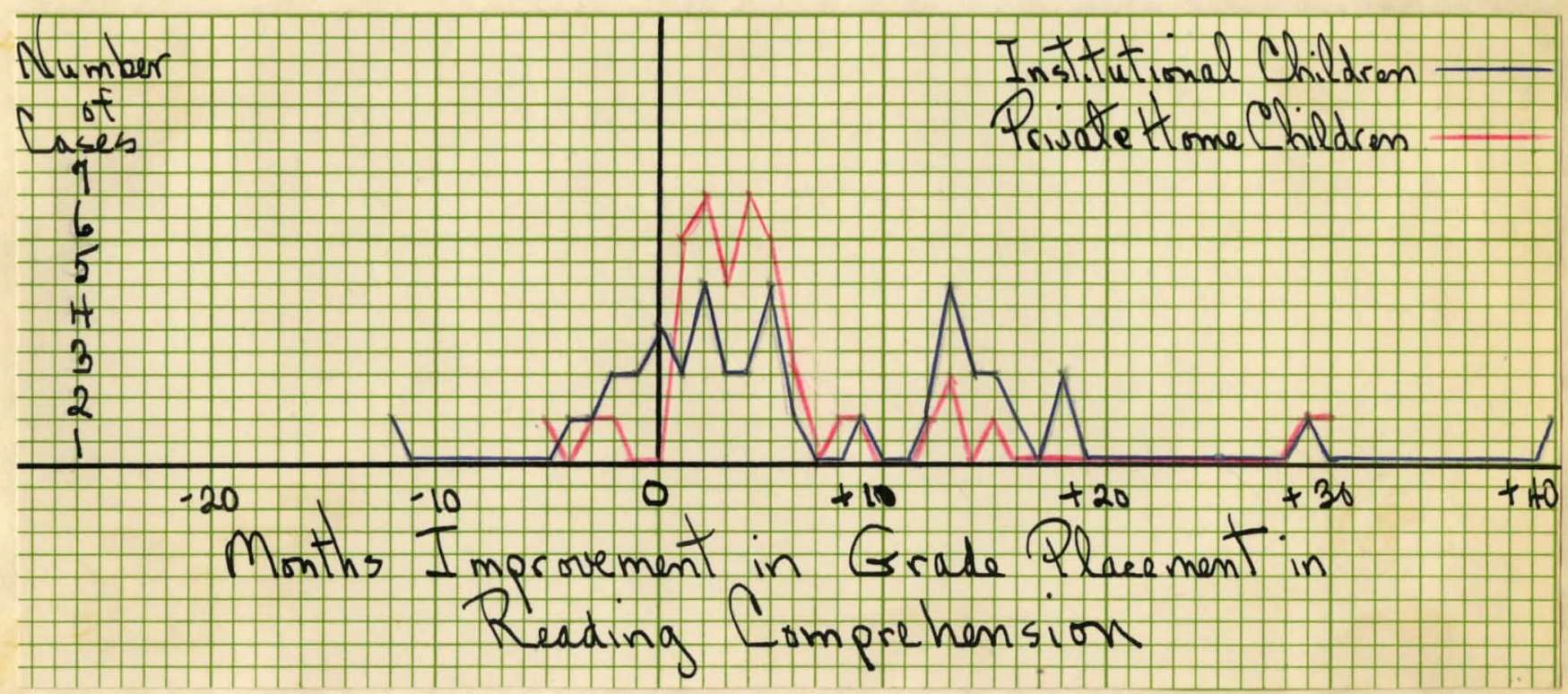

Twenty-one pupils from the institutional group gained over 5 months in the grade placement on the Reading Comprehension Test and two dost over 3 months.

Nineteen pupils from the private home group gained over 5 months in grade placement and 2 pupils lost over 3 months. 
TABLE XXX

RESULTS OF THE PROGRESSIVE ACHIEVEMENT TEST IN LANGTAGE IN GRADE PLACEMENT ADMINISTERED OCTOBER 1943 AIND JANUARY 1944 TO FORTY INSTITUTIONAL CHILDREN AND FORTY CHILDREN FROM PRIVATE HOMES

Institutional Chiloren

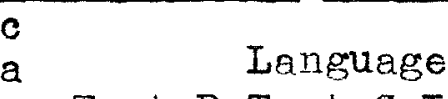

s Test B Test C Improve.
Private Home Children

a Lenguage

$s$ Test B Test C Improve.

$\frac{1}{2}$

$2 \quad 5.9 \quad 5.4$

$3 \quad 6.4$

45.3

$5 \quad 7.5$

67.4

75.1

85.0

$\begin{array}{rr}9 & 6.0 \\ 10 & 7.0\end{array}$

115.8

125.3

$13 \quad 8.6$

147.1

157.3

$16 \quad 6.8$

$17 \quad 8.6$

$18 \quad 6.8$

$19 \quad 5.6$

$20 \quad 7.0$

218.0

22

23

24

25

26

27

8.0
9.0

6.8

6.2

5.7

7.4

7.3

5.2

6.6

7.4

6.2

6.4

9.0

7.4

7.9

7.0

8.7

6.8

6.4

6.8

8.2

7.9

6.8

6.2

7.0

6.8

6.5

6.7

28

6.2

6.6

29

6.8

7.0

30

6.8

7.3

31

7.2

6.9

32

7.8

33

8.1

4.7

5.6

34

7.4

7.9

35

7.0

7.8

36

7.0

7.5

37

$$
6.8
$$

6.9

38

7.8

7.0

39

7.0

7.1

7.9

8.0

Lowest

score $3.9 \quad 4.8$

hedian6.8 $\quad 7.0$

$7.0+2$

Highest

score $9.0 \quad 9.0$

-2
-9
4
9
-20
0
16
2

$\Theta$

$\begin{array}{lll}5.4 & 5.5 & 1 \\ 6.4 & 6.8 & 4\end{array}$

$\begin{array}{llll}3 & 5.7 & 6.0 & 3\end{array}$

46.7

58.2

6.7

67.0

8.9

3

$7 \quad 7.2$

88.9

9

5.6

7.8

7.5

6.9

$10 \quad 6.4$

5.8

$11 \quad 7.0$

6.4

127.0

7.4

13

5.8

7.7

14

7.1

5.5

15

7.0

7.4

16

7.0

7.3

$17 \quad 7.0$

7.4

18

19

6.4

7.4

$20 \quad 7.8$

21

22

23

24

25

26

27

28

29

6.8

7.0

6.5

7.5

8.3

7.2

7.3

7.4

6.8

6.3

7.7

6.7

7.4

7.6

7.0

6.8

7.8

7.4

6.5

7.6

7.2

7.8

30

6.5

7.2

7.0

7.4

32

6.4

8.1

8.3

33

7.5

9.0

7.5

8.9

35

8.2

9.2

37

8.8

6.0

$\begin{array}{ll}1 & 38 \\ 1 & 39 \\ 5 & 40\end{array}$

6.4

7.9

$\begin{array}{ll}1 & 38 \\ 1 & 39 \\ 5 & 40\end{array}$

7.0

7.8

7.0

7.4

7

7

3

$-24$

$-2$

0

4

7
-3

3

3

4

0

1

5

4

1

9

4

2

8

13

7.3

4.7

4.8

$7.0 \quad 7.4$

$+4$

8.99 .2 


\section{TABLE XXI}

STATISTICAL SIGNIFICAINE OF THE DIFFERTICH BHTWEEN FORIY INSTITUIONAL CHILDEEN AND HORTY CHILDREN FROA PRIVATE HOMES ON IIIT IAAVGUAGE OF TITE PROGRESSIVE ACHIEVEIAENT TEST FORN B ADMIVISTERED OCTOBER 1943

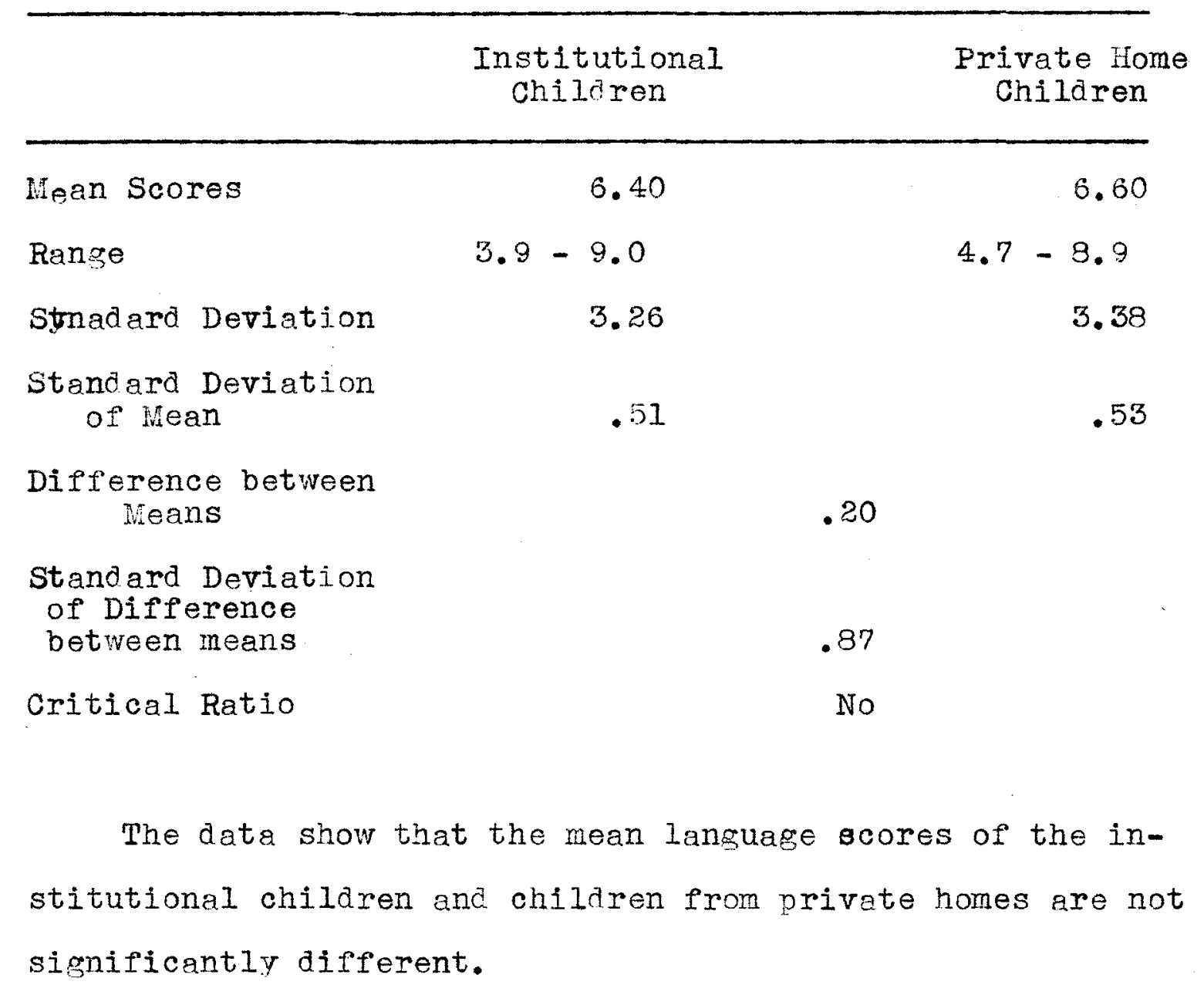




\section{GRAPH $\underline{V}$}

\section{MOINTS IMPROVEWVINTT IN GRADE PLACEMNENT IN LANGUAGE OF THE PROGRESSIVE ACHIEVEMENT TEST ADNINISTERHD TO FORTY INSTITUTIONAL CHILDREN AND FORTY CHIIDREN FROM PRIVATE HOMES}

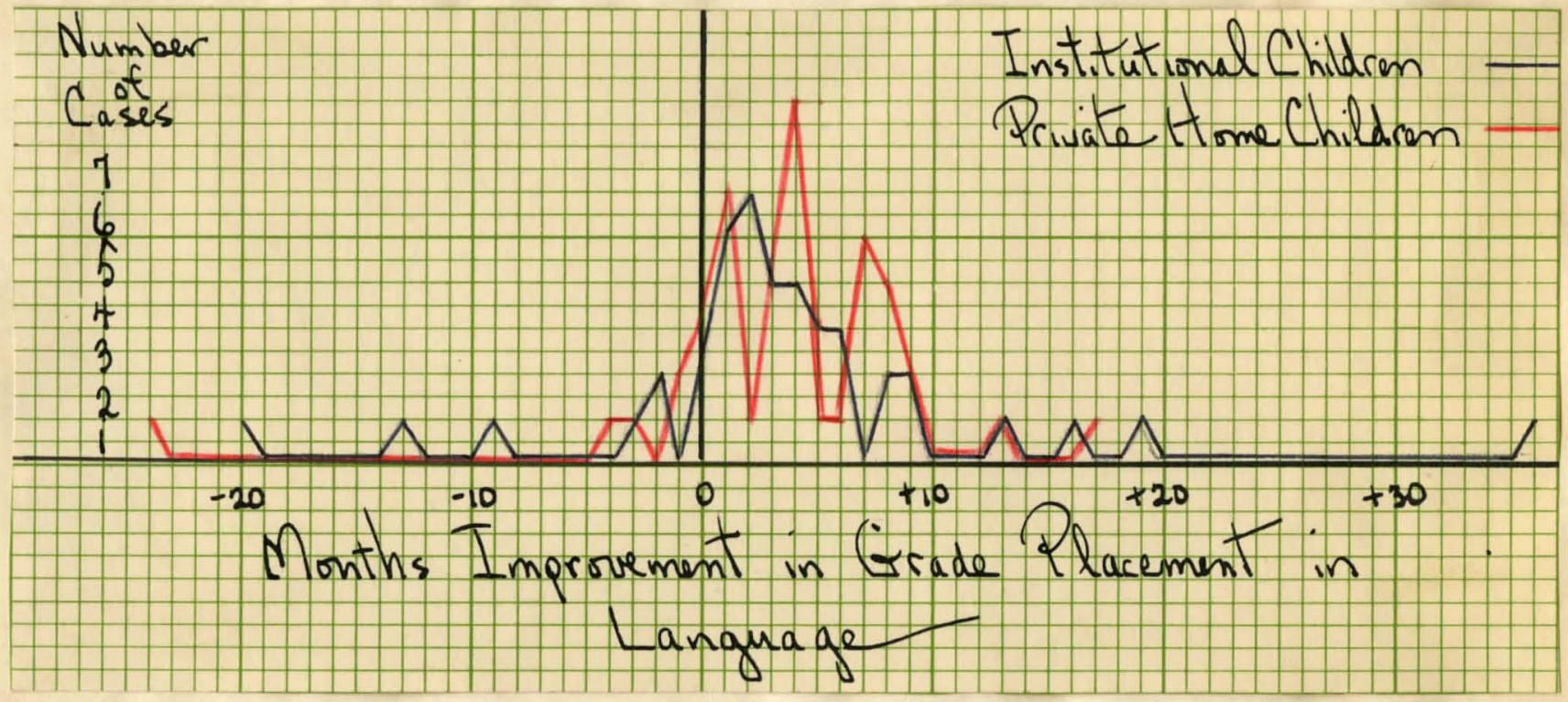

Fifteen institutional children gained over 5 months in grade placement in Language while four children lost over three months.

Fifteen pupils from private homes gained over five months in grade placement and three pupils lost over three months. 


\section{TABLE XXII}

STATISIICAI SIGINI FICANCE OF THE DIFFERENCES BETWEEN FORTY INSTITUTIONAL CHILDREN AID FORTY CHILDREN FRON PRIVATE HOMES ON TIE LANGUAGE OF IHE PROGROSSIVE ACFI EVEMENT TEST FORM C ADIIINISTERED JAIVUARY 1944

\begin{tabular}{|c|c|c|c|}
\hline & $\begin{array}{c}\text { Institutional } \\
\text { Children }\end{array}$ & & $\begin{array}{c}\text { Private Home } \\
\text { Children }\end{array}$ \\
\hline Mean Scores & 6.50 & & 6.73 \\
\hline Range & $4.7-8.9$ & & $4.8-9.2$ \\
\hline Standard Deviation & 2.98 & & 3.68 \\
\hline $\begin{array}{l}\text { Standard Deviation } \\
\text { of Mean }\end{array}$ & 4.6 & & 5.7 \\
\hline $\begin{array}{l}\text { Difference between } \\
\text { Means }\end{array}$ & & .23 & \\
\hline $\begin{array}{l}\text { Standerd Deviation } \\
\text { of the Difference } \\
\text { between Means }\end{array}$ & & 2.01 & · \\
\hline Critical Ratio & & .121 & \\
\hline Significant & & No & \\
\hline
\end{tabular}

These data indicate that there were no significant difference in the language test results of the institutional children and the children from private homes. 
In the Arithmetic Reasoning the institutional children made a gain of 8 months, from 6.0 to 6.9 , during the four months. The range in grade placement is from 4.4 to 7.5 in Test $B$, see Table XXIII. The children from the private homes made a gain of 5 months in grade placement from 6.5 on Test $B$ to 7.0 on Test $C$. The range in grade placement is from 3.8 to 7.5 in Test $B$.

Again, in Arithmetic Fundamentals the institutional children made the greatest gain, a progress of seven months in grade placement. On Test B, Table XXYI, the median score was 6.7 and on Test $C$, the score was 7.4. The range on Test $C$ was from 5.0 to 9.5. The children from the private home group made an improvement of 4 months in Arithmetic Fundamentals. The span in the grades of Test $C$ was 5.7 to 9.5 . The greatest gain was made by a boy from the private home group a gain from 3.9 to 7.2 , or 3 and 3 tenths grade.

The greatest improvement in all tests was made by the chilaren from the institutional group in Arithmetic reasoning and Arithmetic Fundamentals, with an average gain of eight months in the total arithmetic score. This may be due to the fact that arithmetic is a more concrete and drill subject than language or reading. It is much easier for one child to aid another pupil in arithmetic than in reading, and since the 
orphans help each other at home, this may account for the greater improvement.

In checking over the improvement in the Total Grace Placement it was from the institutional children made an average gain of six months, from 6.4 to 7.0 . The private home group gained 5 months from 6.6 to 7.1 , Table XXIX. This is a difference of only one month in the total achievement of the children from the private homes and the children from the institution.

Table XXXI shows the placement as to grade and quartile rank of each child irom the institution. 


\section{GRAPH VI}

MONTHS IMPROVEMENT IN GRADE PLACHMENT IN ARITHMETIC

REASONING OF THE PROGRESSIVE ACHIEVEMTNT TEST

ADMINISTERED TO FORTY INSTITUPIONAL CHILDRFN

AND FORTY CHILDREN FROM PRIVATE HOMRS

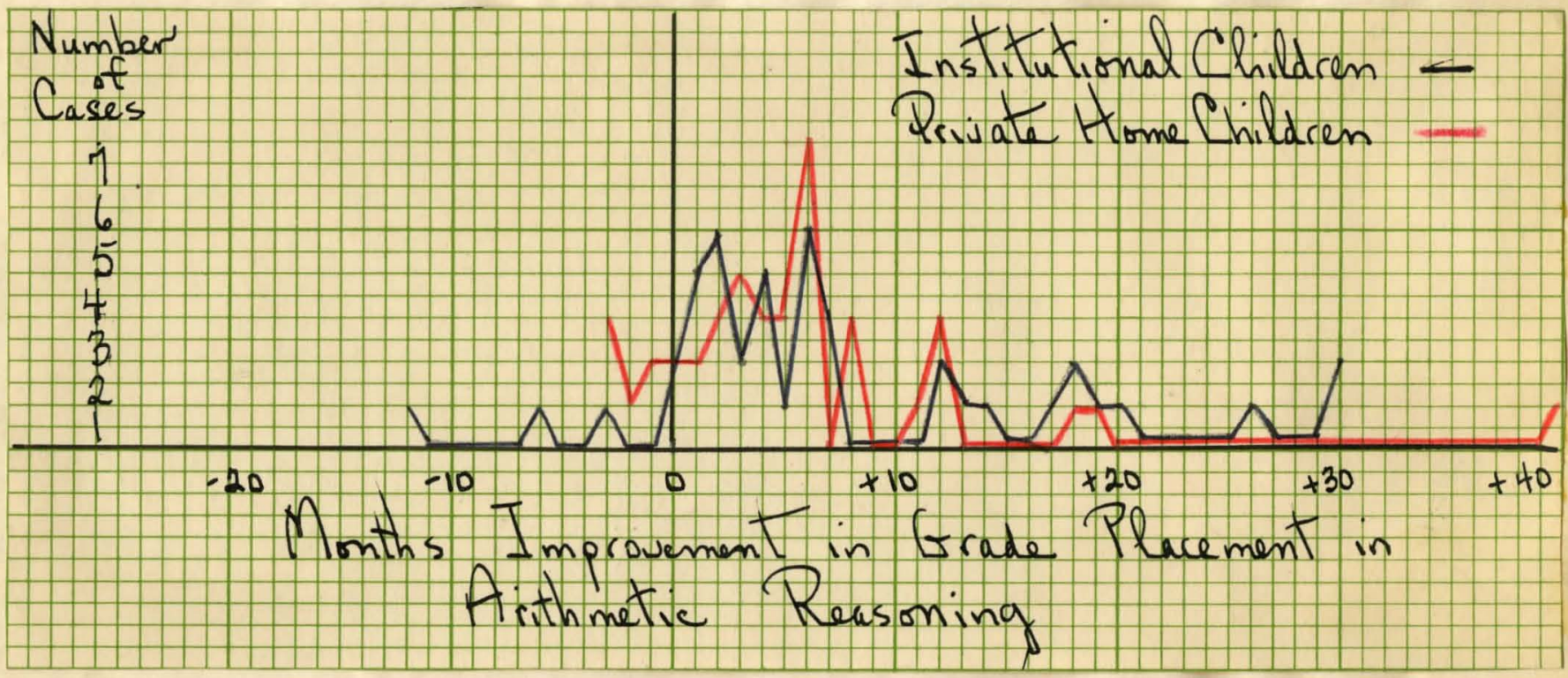

Twenty-one pupils from the institution gained over 5 months in grade placement in Arithmetic Reasoning and three pupils lost over 3 months.

In the private home group twenty-two pupils gained over 5 months in grade placement and one child lost 3 months. 


\section{TABLE XXIII}

RESULTS OF THE PROGRESSIVE ACHIEVEMTNT TEST IN ARTTHMEIIC REASONING IN GRACE PLACEMEMT ADMINISTERED OCTOBER 1943 AND JANUARY 1944 TO FORTY INSTITUTIONAI CHILDREN AND FORTY CHIIDREN FROM PRIVATE HOMES

Institutional Chilaren

c Arithmetic Reasoning

a Test B Test C Improve.
Private Home Children Arithmetic Reasoning

Test B Test C Improve.

$s$

e

$$
\begin{aligned}
& 2 \\
& 3
\end{aligned}
$$

3

4
5

8

9

10

11

\section{2}

\section{3}

14

15

16
17

18

19

20

21

22

23

25

26

27

28

29

30

31

32

33

34

35

36

37

38

39

40

Low

score 4.4

Median6. 0

High

score 7.5

6.3

6.3

5.5

5.2

7.4

5.6

6.0

6.9

7.0

7.5

7.4

7.3

7.3

6.0

6.0

6.0

5.0

6.0

4. 6

6.2

6.4

4.7

5.9

6.0

7.3

7.5

6.9

5.5

7.5

6.2

7.4

5.1
4.9
6.3

5.2

6.9

6.8

5.6

4.4

4.3

6.9

5.9

6.3

6.8

6.3

4.6

7.2

7.0

6.5

5.8

7.8

5.9

7.2

6.9

7.1

7.9

7.6

7.9

7.5

7.5

6.3

6.1

7.3

7.6

6.3

6.3

6.7

5.8

6.5

6.3

6.3

8.0

8.7

8.1

7.9

7.8

10.0

5.8

4.6

6.8

10.0

1

2

3

4

5

6

7

8

9

10

11

12

13

15

16

17

18

19

20

21

22

23

24

25

26

27

28

29

30

31

32

33

34

35

36

37

38

39

80

$\begin{array}{llr}6.8 & 7.2 & 4 \\ 6.0 & 5.9 & -1 \\ 5.7 & 6.3 & 6 \\ 6.0 & 6.6 & 6 \\ 7.5 & 8.0 & 5 \\ 6.5 & 7.5 & 12 \\ 5.8 & 6.3 & 5 \\ 7.3 & 7.0 & 3\end{array}$

4.8

3.7

8.3

6.57 .3

13

5.0

5.7

6.0

5.6

8.3

7.2

7.6

6.7

7.2

7.3

6.8

6.3

6.5

6.2

3.8

6.0

6.2

5.8

7.3

6.3

6.1

6.2

6.0

6.5

5.1

8.9

6.7

7.3

7.0

7.0

6.7

7.3

6.8

7.2

6.4

7.3

6.7

7.3

6.6

6.7

.6 .4

6.3

7.2

6.5

5.2

8.3

6.5

7.4

6.7

7.2

7.2

8.3

6.2

5.8

7.9

3.1

7.2

3.8

6.5

5.2

7.5

7.0

8.4
6

12

$-1$

13

3

0

1
-3

2

4

6

6

40

4

13

9

0

3

6

2

3

$?$

19

2

$-2$

13

18

6
9

.5 


\section{TABLE XXIV}

STATISTICAL SIGIIFICANCE OF THE DIFTERENCES BETWEEN FORTY INSTIPUTIONAL CHILDREN AND FORTY CHILDREN FROM PRIVATE HOMES ON THE ARITHWETIC REASONING OF THE PROGRESSIVE ACHIEVERTITT TEST FORM B ADIINISTERED OCTOBER 1943

Institutional

children

Private Home Chilaren

Mean Scores

6.13

6.03

Bange

$4.4-7.5$

$2.8-7.5$

Standard Deviation

2.41

2.08

Standard Deviation

of Mean

.38

.33

Difference between

Means

.05

Standard Deviation of

difference between

Means

1.23

Critical Ratio

.04

Significant

No

The data indicate there is no significant difference between the arithmetic reasoning scores of the two groups. 


\section{TABLE XXV}

STATISTICAL SIGNIFICANCE OF THE DIFFERENCES BETHEHN FORTY INSTITUTIONAL CHILDREN AND FORTY CHILDREN FROM PRIVATE HOMES ON THE ARITHATTIC REASONING OF THE PROGRESSIVE ACHI IJVEMIENT TEST FORIA C ADIIIVISTERED JANU ARY 1944

\begin{tabular}{|c|c|c|c|}
\hline & $\begin{array}{l}\text { Institutional } \\
\text { Children }\end{array}$ & & $\begin{array}{l}\text { Private Home } \\
\text { Children }\end{array}$ \\
\hline Mean Scores & 6.4 & & 6.6 \\
\hline Range & $4.6-8.2$ & & $5.2-8.4$ \\
\hline Standard Deviation & 2.84 & & 3.17 \\
\hline $\begin{array}{l}\text { Standard Deviation } \\
\text { of Ifean }\end{array}$ & .45 & & .50 \\
\hline $\begin{array}{l}\text { Difference between } \\
\text { Means }\end{array}$ & & .20 & \\
\hline $\begin{array}{l}\text { Standard Deviation } \\
\text { of the Difference } \\
\text { between means }\end{array}$ & & .86 & \\
\hline Critical Ratio & & .23 & \\
\hline Significant & & No & \\
\hline
\end{tabular}

No significant difference of the scores in Arithmetic Reasoning was show by the above data. 


\section{GRAPH VII}

MONTHS IMPROVENENT IN GRADE PLACHMENT IN ARITHMETIC

FUNDAMEINTALS OF THE PROGRESSIVE ACHIEVEMENT TIST

ADNINISTERED TO FORTY INSTITUIIONAL CHILDREN AND FORTY CHILDREN FROM PRIVATE HOMES

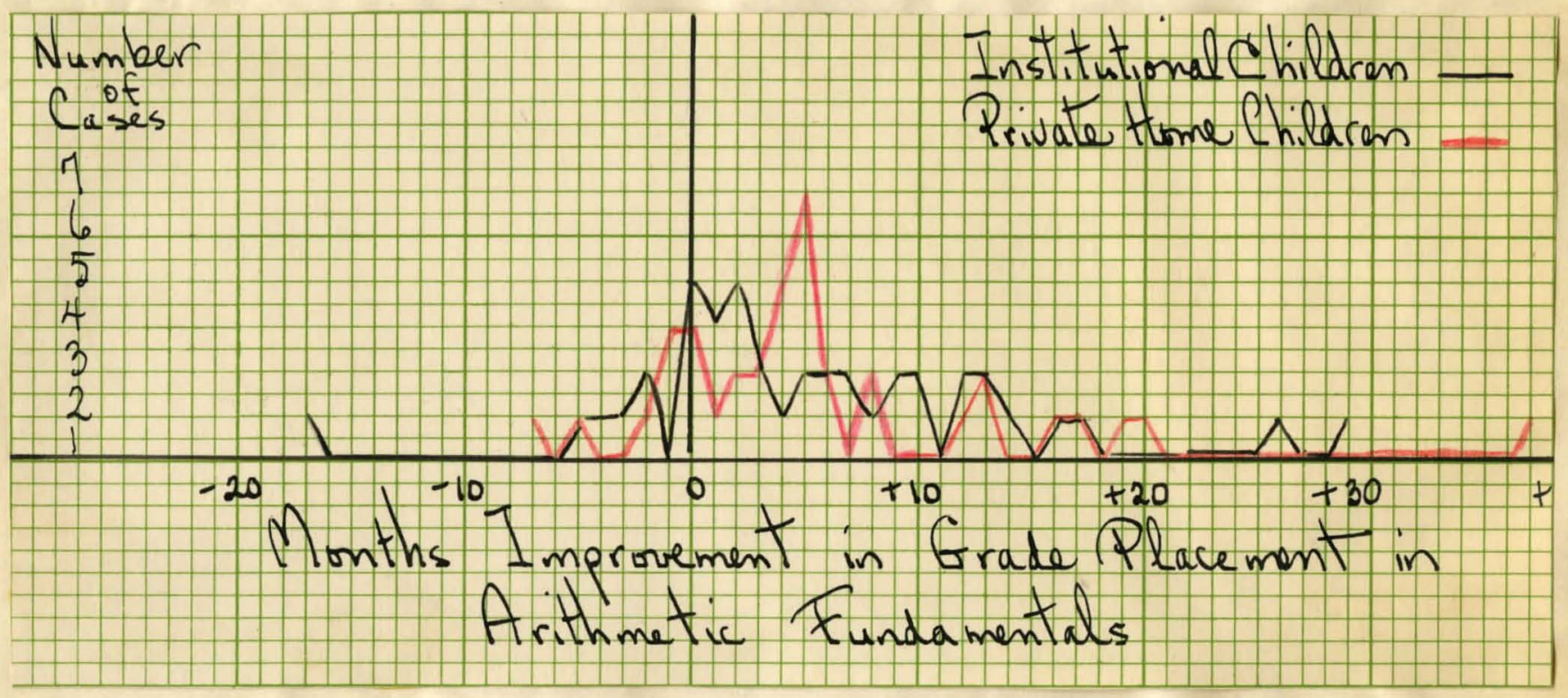

Nineteen pupils from the insitutional group gained over 5 months in grade placement in arithmetic Fundamentals and 5 pupils lost over 3 months.

Twenty-one pupils from the private home group gained over 5 months in grade placement and 2 lost over 3 months. 
TABLE XXVI

RESULTS OF THE PROGRESSIVE ACHIEVENIENT TEST IN ARITHMETIC FUNDAMEINTALS IN GRADE PLACEMENT ADMINISTERED OCTOBIR 1943 AND JANUARY 1944 TO FORTY INSTITUTIONAL CHILDREN AND FORTY CHILDREN FROM PRIVATE HOMES

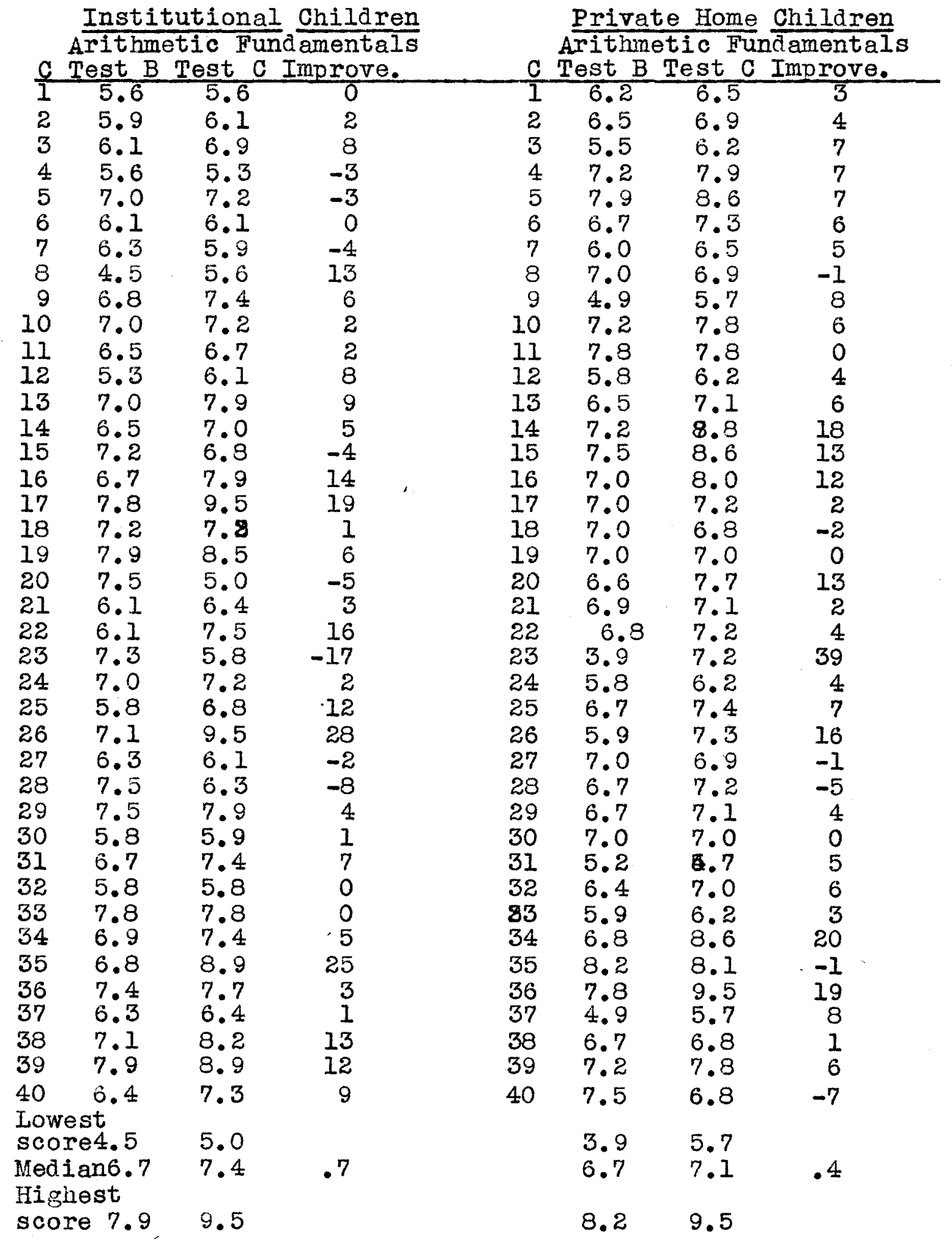




\section{TABLE XXVII}

STATISTICAL SIGNIFICANCE OF THE DIFTERENCES BETIEEN FORTY INSTITUTIONAL CHILDREN AND FORTY CHIIDREN FROH PRIVATE HOMES ON THE ARITHMETIC FUNDAMEIVTALS OF THE PROGRESSIVE ACHIEVERMENT TEST FORM B ADMINISTERED OCTOBER 1943

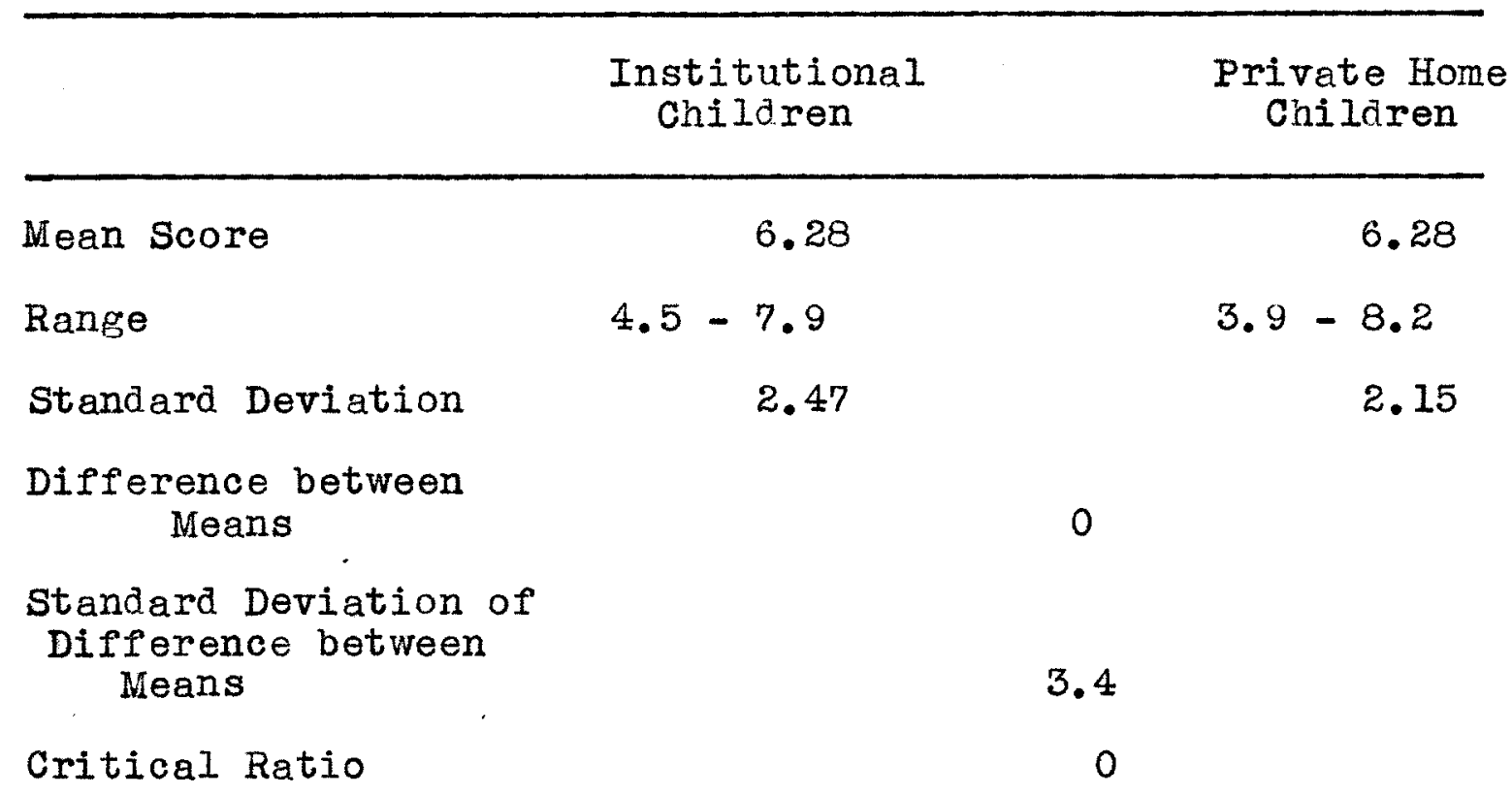

These data indicate that the mean arithmetic fundamental scores of the forty children from the institution and forty children from orivate homes are not significantly different. 


\section{TABLE XXVIII}

STATISTICAL SIGNIFANCE OF THE DIFFERENCES BETWEEN FORTY

INSTITUTIONAL CHIIDREN AND FORTY CHIIDREN FRON PRIVATE HOHES ON THE ARITHEMETIC FUNDAMENTALS OF THE PROGRESSIVE ACHIEVEMENT TEST FORM C ADMINISTERED JAIVUARY 1944

\begin{tabular}{|c|c|c|c|}
\hline & $\begin{array}{l}\text { Institutional } \\
\text { Children }\end{array}$ & & $\begin{array}{l}\text { Private Home } \\
\text { Children }\end{array}$ \\
\hline Mean Scores & 6.75 & & 6.77 \\
\hline Range & $5.0-9.5$ & & $5.7-9.5$ \\
\hline Standard Deviation & 3.60 & & 3.76 \\
\hline $\begin{array}{l}\text { Standard Deviation of } \\
\text { Mean }\end{array}$ & .57 & & .60 \\
\hline $\begin{array}{c}\text { Difference between } \\
\text { Means }\end{array}$ & & .02 & \\
\hline $\begin{array}{c}\text { Standard Deviation of } \\
\text { Difference between } \\
\text { Means }\end{array}$ & & 1.44 & \\
\hline Critical Ratio & & .017 & \\
\hline Significant & & No & \\
\hline
\end{tabular}

The data showed that the mean aritmetic fundamental scores of the institutional group and the group from private homes were not significantly different. 


\section{TABLE XXIX}

\section{RESULTS IN GRADE PLACEMENT OF THE PROGRESSIVE ACHIEVENENTS TESTS FORMS B AND C ADIINISTERED OCTOBER 1943 AND JANUARY 1944}

INSTITUTION Read. Read. Arith. Arith. Lang. Total Grade
CHILDREN
Voc. Comp. Reas. Fund.

Median

Test B

$6.16 .6 \quad 6.0$

6.7

6.8

6.4

Median

Test $\mathrm{C}$

$6.5 \quad 6.96 .8$

7.4

7.0

7.0

Improvement

In Grade

Placement
.3

.8

.7

.2

.6
PRIVATE HOME Read. Read. CHILDREN
Read.
Comp.

Arith. Reas.
Arith. Lang. Fund.
Total Grade Placement

Median

Test B

$$
6.5
$$

6.5

6.5

6.7

7.0

6.6

Median

Test C

6.7

7.1

7.0

7.1

7.4

7.1

Improvement

In Grade

Placement

$.2 \quad .6$

.5

.4

.4

.5 
Compare this with the Grade Placement chart, Table XXXX for all members of the sixth grade minus the institutional children. The results of the two tables are to be found in Table XXXII. The sixth grade children minus the orphans are up to the Louisville City median in all subjects and one grade ahead of the City median in Arithmetic Reasoning. The institutional children were up to the standard set by the city in all subjects of Progressive Achievement Test, Form $B$, and one term ahead in Reading Comprehension.

The children from the private home group compared favorably with the city median, being superior to the city in Reading Vocabulary, Reading Comprehension, and Arithmetic Reasoning. The Total Grade Placement Scores of both groups equal to the standard City median for the sixth grades.

\section{Summary}

1. There was no significant difference between the I. Q.'s of the 116 students of the $6 \mathrm{~A}$ grade and the forty pupils from the institution.

2. The forty institutional pupils were three months older chronologically than the forty pupils of the control group from private homes.

3. There was one year and one months difference in the chronological age span of the two groups. The institutional 


\section{TABLE}

RESULTS OF THE PROGRESSIVE ACHIEVEMENT TEST ELEMENTARY BATTERY - FORUA $B$, AS TO GRADE PLACENENT AND UPPER AND LOWER QUARTILES, ADIINISTERED TO AIL SIXTH GRADE STUDENTS MIRUS THE INSTITUTIONAL CHILDREN

\begin{tabular}{|c|c|c|c|c|c|c|c|}
\hline & $\begin{array}{l}\text { cade } \\
\text { oore }\end{array}$ & $\begin{array}{l}\text { Read. } \\
\text { Voc. }\end{array}$ & $\begin{array}{l}\text { Read. } \\
\text { Comp. }\end{array}$ & $\begin{array}{l}\text { Arith. } \\
\text { Reas. }\end{array}$ & $\begin{array}{l}\text { Arith. } \\
\text { Fund. }\end{array}$ & Lang. & Total \\
\hline 9.5 & $\begin{array}{l}10 \\
-\quad 10 \\
\end{array}$ & 2 & 1 & & & & \\
\hline 9.0 & $\begin{array}{l}9 \mathrm{~A} \\
-\quad 9.5 \\
\end{array}$ & 1 & & & & & \\
\hline 8.5 & $\begin{array}{l}9 B \\
-\quad 9.0 \\
\end{array}$ & 5 & 2 & & & 2 & \\
\hline $8.0^{\varepsilon}$ & $\begin{array}{l}8 \mathrm{~A} \\
-8.5 \\
\end{array}$ & 4 & 1 & & 2 & 5 & \\
\hline $7.5^{8}$ & $\begin{array}{l}8 B \\
-8.0 \\
\end{array}$ & 5 & 3 & 1 & 12 & 6 & 2 \\
\hline $7.0^{\prime \prime}$ & $\begin{array}{l}7 \mathrm{~A} \\
-7.5 \\
\end{array}$ & 5 & 4 & 11 & $\frac{15}{10}$ & 15 & 16 \\
\hline $6.5 ?$ & $\begin{array}{l}7 B^{2} \\
-7.0\end{array}$ & $\frac{6}{7}$ & 10 & $\frac{17}{12}$ & 35 & 39 & $\frac{10}{15}$ \\
\hline $6.0^{6}$ & $\begin{array}{l}6 A \\
-6.5 \\
\end{array}$ & 21 & $\frac{7}{17}$ & 25 & $\frac{14}{15}$ & $\frac{22}{4}$ & 45 \\
\hline 5.5 & $\begin{array}{l}6 \mathrm{~B} \\
-6.0 \\
\end{array}$ & 13 & 34 & $\frac{11}{11}$ & 8 & 12 & 17 \\
\hline $5.0^{5}$ & $\begin{array}{l}5 \mathrm{~A} \\
-5.5\end{array}$ & $\frac{19}{6}$ & $\frac{13}{1}$ & 13 & 3 & 7 & 8 \\
\hline 4.5 & $\begin{array}{l}5 B \\
-5.0 \\
\end{array}$ & 9 & 14 & 3 & 1 & 3 & 3 \\
\hline $4.0^{4}$ & $\begin{array}{l}4 A .5 \\
-\quad 4.5 \\
\end{array}$ & 10 & 12 & & 1 & 2 & \\
\hline 3.54 & $\begin{array}{l}4 \mathrm{~B} \\
-\quad 4.0 \\
\end{array}$ & 2 & 2 & 1 & & & \\
\hline $3.0^{3}$ & $\begin{array}{l}3 \mathrm{~A} \\
-\quad 3.5 \\
\end{array}$ & 1 & 1 & 1 & & & \\
\hline
\end{tabular}


TABLE XXXI

RESULTS OF THE PROGRESSIVE ACHIEVEMENT TEST

ELEMENTARY BATTERY - FORM B,

AS TO GRADE PLACEMENT AND UPPER AND LOWRR QUARTILES,

ADMINISTERED TO FORTY INSTITUTIONAL CHILDREN

\begin{tabular}{|c|c|c|c|c|c|c|}
\hline $\begin{array}{l}\text { Grade } \\
\text { Score }\end{array}$ & $\begin{array}{l}\text { Read. } \\
\text { Voc. }\end{array}$ & $\begin{array}{l}\text { Read. } \\
\text { Comp. }\end{array}$ & $\begin{array}{l}\text { Arith. } \\
\text { Reas. }\end{array}$ & $\begin{array}{l}\text { Arith. } \\
\text { Fund. }\end{array}$ & Lang. & Total \\
\hline $\begin{array}{c}10 \\
9.5-10 \\
\end{array}$ & & & & & & \\
\hline $\begin{array}{c}9 A \\
9.0-9.5 \\
\end{array}$ & 2 & & & & & \\
\hline $\begin{array}{c}9 B \\
8.5-9.0 \\
\end{array}$ & & 2 & & & 1 & \\
\hline $8.0^{8 A}-8.5$ & 1 & 2 & & & 2 & \\
\hline $\begin{array}{c}8 B \\
7.5-8.0 \\
\end{array}$ & & 3 & & 2 & 6 & \\
\hline $7.0^{7 A}-7.5$ & 2 & $\frac{3}{3}$ & 8 & $\frac{8}{3}$ & $\frac{1}{7}$ & 10 \\
\hline $\begin{array}{c}7 \mathrm{~B} \\
6.5-7.0 \\
\end{array}$ & $\frac{5}{5}$ & 7 & $\frac{2}{2}$ & 9 & 8 & 9 \\
\hline $\begin{array}{c}6 A \\
6.0-6.5 \\
\end{array}$ & 5 & 4 & 7 & 4 & 3 & 11 \\
\hline $\begin{array}{c}6 \mathrm{~B} \\
5.5-6.0 \\
\end{array}$ & $\frac{10}{1}$ & $\frac{6}{1}$ & 9 & $\frac{4}{4}$ & $\frac{2}{3}$ & 4 \\
\hline $\begin{array}{c}5 A \\
5.0^{-}-5.5 \\
\end{array}$ & 4 & 7 & $\frac{2}{5}$ & 4 & 3 & 5 \\
\hline $4.5-5 B$ & 2 & 2 & 4 & 2 & 3 & 1 \\
\hline $4.0^{4 A}-4.5$ & 1 & & 1 & & & \\
\hline $\begin{array}{c}4 B \\
3.5-4.0 \\
\end{array}$ & $\underline{2}$ & & & & 1 & \\
\hline
\end{tabular}

City Median 


\section{$\underline{T A B L E} \quad \underline{X X X I I}$}

RESULTS IN GRADE PLAC 证IENT OF THE PROGRESSIVE

ACHIEVEHENT TEST ELEMENTARY BATTERY FORM B ADMINISTERED TO 1673 SIXTH GRADE WHITE PUPILS

IN THE LOUISVILLE PUBLIC SCHOOLS

Read. Read. Arith. Arith. Lang. Total Grade Voc. Comp. Reas. Fund. Placement

$\begin{array}{lcccccc}\text { City Median } & 6 \mathrm{~B} & 6 \mathrm{~B} & 6 \mathrm{~B} & 6 \mathrm{~A} & 6 \mathrm{~A} & 6 \mathrm{~A} \\ \begin{array}{l}\text { Ingelhard } \\ \text { Median }\end{array} & 6 \mathrm{~B} & 6 \mathrm{~B} & 6 \mathrm{~A} & 6 \mathrm{~A} & 6 \mathrm{~A} & 6 \mathrm{~A} \\ \begin{array}{l}\text { Institution } \\ \begin{array}{l}\text { Children's } \\ \text { Median }\end{array}\end{array} & 6 \mathrm{~B} & 6 \mathrm{~A} & 6 \mathrm{~B} & 6 \mathrm{~A} & 6 \mathrm{~A} & 6 \mathrm{~A} \\ \begin{array}{l}\text { Private Home } \\ \begin{array}{l}\text { Children's } \\ \text { Median }\end{array}\end{array} & 6 \mathrm{~A} & 6 \mathrm{~A} & 6 \mathrm{~A} & 6 \mathrm{~A} & 6 \mathrm{~A} & 6 \mathrm{~A}\end{array}$


group had the widest range.

4. The children from the institution have repeated a total of 27 terms in their six years of elementary school work compared to 22 terms from the private home group.

5, During the experimental period the institutional pupils made an average progress of 6 months in grade placement. The private home pupils made 5 months gain.

6. The institutional pupils made more progress than the private home group in grade placement in reading vocabulary arithmetic fundamentals and arithmetic reasoning.

7. The private home group surpassed the institutional group in reading comprehension and language.

8. The comparison of the progress of bach group statistically showed by the standard deviation that there was no significant difference between the institutional group and the the private home group in achievement.

9. The private home pupils were 5 months above the Louisville median in all subjects of the Progressive Achievement Test.

10. The institutional pupils nade the city median in all subjects and were 5 months above in arithmetic and language. 


\section{CHAPTER V}

\section{PERSONALITY FACTORS}




\section{CHAPTER V}

\section{PERSONAIITY FACTORS}

There is probably no other subject of more interest than that of personality evaluation. As we meet people, we more or less consciously, tend to judge their personality characteristics in terms of our own prejudices and their responses at the time. This interest in personality is as old as the human race.
"The term personality is generally used to designate the organization and integra- tion of a large number of human traits. The word does not lend itself to a pre- cise definition, although the concept of personality includes many traits that can be studies objectively and quanitatively. Personality develops from the integra- tion of physical, mental, emotional, apt- itudinal, and environmental factors. An individual's personality represents a complex picture of his physical ap- pearances, his degree of mentality, his emotional and social behavior patterns, his attitude toward people and things, and the observable techniques that he employs as he responds to the daily stimulations of the elements of his environment." 1

It is quite easy to recognize an adjusted personality but difficulty is experienced in trying to aescribe or develop it. Teachers have long been aware of the fact that achievement and intelligence tests alone do not furnish information concerning certain vital intangibles related to desirable and

\footnotetext{
1

Alice Crow, and Lester Crow, "Mental Hygiehe in School",
} $1942, \mathrm{p} .426$. 
undesirable behavior.

In this thesis an attempt is made to study these vital intagibles and to compare the parsonalities of a group of institutional children with the personalities of a group of children from private homes in order to determine if differences do exist and to determine the efiect of institutional life on the personality of the children.

In attempting to delve into this problem of personality Symonds says:
"The direct attack by observation, rating, an and questionnaire, carried out systematical- ly by group survey methods, offers the best hope of discovering problem children and those suffering from malajustments. School achievement and intelligence tests, spec- ial tests of social intelligence and like measures of environment all have certain diagnostic signiflcance. But it should be emphasized again that the proper place for much of this information to be gathered is in the school room where it can be done faitly, intelligently, with- out excitement or pressure, and in groups. Information of this type must be obtained when there is no emergency." 1

Teachers constantly collect information relating to the pupils' character traits. At the end of each grading period which was approximately six weeks, every child in the Louisville Public Schools had his citizenship evaluated in terms of Personal, Social, and Work and Play Habits. Only in cases

\footnotetext{
Symonds, Percival, Psychological Diagnosis in Social Adjustment, p. 52 .
} 


\section{TABLE XXXIII}

TEACHER RATING OF CITIZENSHIP OF PUPIIS FROM PRIVATE HONES AND FROM INSTITUTIONS ON THE REPORT CARD OF THE LOUISVILLE PUBIIC SCHOOLS

PERSONAL HABITS

1. Comes to school on time

2. Begins work promptly

3. Has good posture

4. Chooses luncheon wisely

5. Is polite in speech and

6 . Shows reasonable amount of self control

7. Takes pride in his appearance Total

SOCIAI HABITS

1. Respects the rights of others

2. Shows good sportsmanship

3. Helps to carry out suggestions of the group

4. Pays attention when others are speaking

5. Respects public and private Total property

WORK AND PLAY HABITS

1. Responds to directions promptiy

2. Has orderly habits of work

3. Makes good use of his time

4. Shows self-reliance

5. Originates new enterprises for self and group Total

$\mho$ (unsatisfactory) indicates that attention should be

\section{given to this habit.}

No, of U Ratings

Private home Institution Number Percent Number Percent

$\begin{array}{rrrr}5 & .13 & 0 & 1.00 \\ 12 & .30 & 10 & .25 \\ 9 & .23 & 8 & .13 \\ 9 & .23 & 0 & 1.00 \\ 5 & .13 & 8 & .20 \\ & & & \\ 12 & .30 & 10 & .25 \\ 15 & .38 & 8 & .20 \\ 68 & .21 & 44 & .12\end{array}$

$\begin{array}{rrrr}4 & .10 & 10 & .25 \\ 5 & .13 & 15 & .38 \\ 5 & .13 & 10 & .25 \\ 15 & .38 & 14 & .35 \\ 10 & .25 & 8 & .20 \\ 39 & .19 & 57 & .29\end{array}$

$10 \quad .25$

$8 \quad .20$

.25

$20 \quad .50$

10

.25

15

8
20

.38

.20

$20 \quad .50$

30

.50

70

.35

81

.75

.41 
where attention was needed to be called to a habit was a child given a "U", an unsatisfactory grade, by the teacher. Table XXXIII is a copy of $2 F$ form, the report card, used by the teachers of Louisville to grade pupils in citizenship. This table contains a total of the unsatisfactory habits ratings by the teachers of forty institutional children and forty children from private homes for the term.

The results of the teacher's rating of Personal Habits, show that the private home group had the largest total of unsatisfactory habits. The three habits that seem to have the most bearing upon the total were the failure to: 1."Comes to school on time." 4. "Chooses lunch wisely." and 7. "Takes pride in appearance."

There were only two cases of tardiness among the institutional children while there were 54 cases from the pupils of the private homes. The institutional children had a rigid schedule of a definite rising time, morning routine, and a definite time of leaving the orphanage for school under the supervision of a matron, who marched them to school.

The lack of parental supervision and regular habits. in private homes greatly affected the children's punctuality. Fifteen children out of forty or thirty-eight percent from private homes were rated unsatidfactory in personal appearances contrasted against eight or twenty percent from the institution. The definite routine in the orphanage of daily baths, oral care, change of clothing, inspection for personal 
cleanliness and neatness accounts for this greater degree of satisfactory personal appearance of the institutional children. The girls took pride in their appearance and often traded clothes so that they may have several different costumes. A person coming into a classroom could not discover the institutional child from another child for he certainly was well dressed and clean.

A different picture was displayed in the results of the teacher's rating of the Social Habits on the report card. There was a total of 57 unsatisfactory ratings of institutional children against 39 such ratings for children of private homes. The greatest difference was in the characteristic of social conduct, "Shows good sportsmanship". Fifteen children or thirty-eight percent from institutions vere rated unsatisfactory in sportsmanship while five or thirtenn percent from private homes were not up to the standards. The feeling of "belongings" and loyalty to the group was so strongly felt among all the institutional children that any criticism of ome child was taken as a personal criticism by all the orphans. Immediately the group was on the defensive for that child. In the sports and all social activities of the school there was a tendency for the institutional children to teem together. They excelled in most of the games due to playground facilities and opportunities 
at the institution for organized play and development of excellent teamwork, yet in instances when they lost, they were poor losers. Several times a few refused to play on teams when they thought they might lose beacuse of the absence of some of the members of their team. In social activities these children were clannish and formed a separate group from other children of the classroom.

The next greatest difference in the Social Habits was the trait, "Respects the Rights of Others". The institutional children had ten "U"'s contrasted against four from the private homes. This was rather surprising as a child who has always had to live and deal with a great number of children should develop the give and take attitude toward others. Among these forty institutional children there were a few who always seemed to be trying to gain a superiority over the group. This constant feeling of aggressiveness and being on the defensive may have caused the disrespect for the rights of others.

In the characteristic, "Helps to Carry Out the Suggestions of the Group", the institutional children had ten unsatisfactory points to five for the private home group. The very fact that they were in an institution linited their ability to do many things with the class group. It was impossible for them to enter into some of the school activities because they interfered with the institutional routine. 
When checking the traits, "Respects Public and Private Property", and "Pays Attention When Others are S peaking", very Iittle difference was found in the totals for the two groups of As noted from the teacher's rating those two traits were most unsatisfactory. The teachers were aware of the need of strengthening these characteristics beacuse of their importance in socilal life.

In the Work and Play Habits, 3. "Makes Good Use of His Time", 4. "Shows Self-reliance", and 5. "Originates New Enterprises for Self and Group", seem to be the most unsatisfactory. Twenty children or fifty percent from private homes were rated unsatisfactory in "Making Good Use of His Time", contrasted against eight or twenty-five percent from the institution. The twenty children were more interested in other things than those prescribed for them at the moment and did not make good use of their time in completing assigned work. They seemed to show initiative and individuality in planning and freedom in carrying out things of heir own interest at the time. The lack of self-reliance was outstanding among the orphanage group. Teachers were conscious of this deficiency of habit which was shown in the following instances: school elections, relying upon one's self for wise choices other than voting for a friend or as someone told tou to rote; standing on one's feet and giving a contribution in class other than rewording a remark given by 
another person or reading directly foor a book; and relying upon one's self for school material necessary for the day's work instead of scrambling around trying to beg some from a friend at the last moment's notice.

The lack of originality was shown by both groups. Thirty out of forty institutional children wee unsatisfactory and twenty of the forty children from private homes were lacking in this trait.

The citizenship rating meant much to the child; in fact, when he recieved his report card his first remark is, "I got U's this time," or "oh, boy, no U's this time." There was a conscious effort on the part of most children to strive to overcome their weakness and thus eliminate the U'S. The fact that a child was able to overcome one of these habits was both gratifying to him and to his parents. The citizenship record in many cases was of more importance then scholarship records to parents for they could forgive poor scholarship much more readily than poor conduct and leck of effort. The institution deprived children of certain privileges for unsatisfactory ratings in such characteristics as "Impolite in Speech and Action", and "Shows Reasonable Amount of Self Control", in an effort to cooperate with the teacher and school, to prevent disobedience, rudeness and impudence.

A personality rating by any one person should not be 
considered final. It requires the computing of many ratings in order to get an adequate evaluation of the personality of a person for diagnostic or judgment purposes. In the evaluation of the personality of the children an informal method of observation was used. According to Strong this method still proves worthwhile.

$$
\begin{aligned}
& \text { "The informal way of studying personality } \\
& \text { which able teachers have always used still } \\
& \text { constitutes best method. It consists in } \\
& \text { observing how other people react to a given } \\
& \text { child and how he behaves in a variety of } \\
& \text { natural situations. If other children } \\
& \text { like him and seek his company, if he himself } \\
& \text { is happy and likes people, we have an indi- } \\
& \text { cation of a good personality. Through in- } \\
& \text { terview and observation the essential, per- } \\
& \text { sistent, predictable core of personality } \\
& \text { can best be ascertained." } 1
\end{aligned}
$$

\section{B Teachers' Ratings}

The four teachers who were in daily contact with the children were asked to observe the students carefully, as to their behavior, moods, and reactions to various situations for the period from October, 1943 through January, 1944. A scale for rating the characteristics of each child was given to these teachers, Table XXXIV. The students were rated 1, superior; 2, average or satisfactory, and; 3 , unsatisfactory, on eacin of the eight points on the scale, Table XXXIV. As every teacher evaluated each characteristic of each child the total number of points per person was thirty-two. The total number of pints for characteristic considered was 160 .

\footnotetext{
Ruth Strong, The Role of Teacher in Personnel Work,
pp. 364-365. Ruth Strong, The Role of Teacher in Personnel Work,
pp. 364-365.
} 


\section{$\underline{\text { TABLE }} \quad \underline{\mathrm{XXXIV}}$}

PERSONALITY RATINGS OF CHILDREN FROM INSTITUTIONS AND FROM PRIVATE HOMES BY FOUR SIXTH GRADE TEACHERS

Characteristics Rated

1. Personal Attractiveness well groomed and attractive 4010020

2. Initiative and Responsibility seeks and creates additional tasks

3. Emotional Control show poise and self control $17 \quad 13122$

4. Purposeful Thinking show original thinking

5. Trustworthiness has keen sense of obligation to others

6. Leadership Ability shows ability to lead in worthwhile projects

$\begin{array}{lll}20 & 68 \quad 72\end{array}$

$\begin{array}{lll}60 & 70 \quad 30\end{array}$

7. Social Adaptability meets differing social situations with ease

$12 \quad 100 \quad 48$

$\begin{array}{lll}38 & 102 \quad 20\end{array}$

8. Speech and Voice excellent diction and well modulated voice

Institutional Private Homes

\begin{tabular}{llllll}
1 & 2 & 3 & 1 & 2 & 3 \\
\hline
\end{tabular}

$50 \quad 100 \quad 30$

$32100 \quad 28$

$\begin{array}{lll}9 & 118 \quad 33\end{array}$

$12 \quad 104 \quad 44$

$22115 \quad 23$

$\begin{array}{lll}28 & 94 & 34\end{array}$

$\begin{array}{lll}32 & 114 & 14\end{array}$

$\begin{array}{llllll}20 & 80 & 60 & 32 & 100 & 28\end{array}$


There was very little difference in the characteristics of "Personal Attractiveness". The institutional children as a whole totaled a few points more because of personal cleanliness which was greatly due to the strict routine of personal habits.

It was found that 63 percent of the institutional children contrasted with 17 percent from private homes were lacking in the trait of "Initiative and Responsibility". The Orphanage regimentation which is often necessary in a large organization seems to stifle initiative whereas in the private homw a child is often forced to seek and create additional tasks.

As stated previously, sixty-seven percent of the mothers from the private homes were employed outside the home. This naturally gave the children more responsibility and freedom. While a member of the institution, a child has rare opporuntity to show original or puroseful thinking, for most problems are solved for him and he has only to accept the plans.

The difference in "Emotional Controls", in both rating scales, between the institutional child and the child from the private home was slight, less than 5 percent, Table XXXIII. The teachers agreed that in most cases, when the school work was well planned and the child was interested, there was little occasion for emotional outbursts.

The teachers agreed as to the trait, "Trustworthiness" 
among the children from private homes and the institutional group. They found this particular group of children from the private home more trustworthy by 20 percent than the institutional children. Since such a great emphasis on the part of the children is put on the marks on the report card, institutional children often find many non-acceptable ways of helping thermselves and friends gain a passing grade. As their test papers are signed each week, the children tried to take home satisfactory grades as good marks often meant speeial privileges. Among this group there were three cases of stealing, which was checked on immediately. A teacher does not hesitate asking the Orphanage to be on the outlook for money or articles which have disappeared for she knows no offense will be taken and the fullest cooperation will be given. In fact, all suspects are urged to be reported at once for the matron wants this trait to be curbed in the beginning. It is sometimes felt that the institutional children have more temptations placed before them at school than other children as they do not have money or individual novelties which children enjoy. Since the orphans are now allowed to do work outside the Home, and have their own bank books this situation has improved.

It is a very precarious situation when a teacher appraches a parent even when she is positive the child has stolen or is not honest in obtaining his work at school. Parents are very sensitive when a lack of honesty is discovered in their 
offspring. The majority of parents do not place so high a value on superior scholarship that the child will go to dishonest means to obtain it.

The teachers felt that there was a closer check on the institutional child than on the children from private homes, and that the orphans were usually caught as they told their friends or divided the spoils ith their companions, while often the other child went free. This may account for the fact that the institutional children are rated less trustworthy.

In traits 6 and 7 , Leadership Ability and Social Adaptability, this rating scale checks with the report card in that the institutional group was inferior to the group from private homes. Over onc half of the institutional children were rated unsatisfactory on both rating scales in leadership and social ability, as is found on Teacher Rating of Pupils Citizenship on the Public School Report Card, Table XXXIII. This may be due to the child's present environment and experience. The institutional supervisor adn routine may have limited the development of leadership and social ability.

There was not a noticeable difference in the trait of "Speech and Voice" between the groups. In some communities where the child was in the habit of hearing correct English well spoken there would have been a marked difference. 
In the rating of personality, Table $X X X I V$, the chilaren from the private homes excelled to a noticeable degree in the following traits, "Initiative and Responsibility, Purposeful Thinking, Leadership, Ability and Social Adaptability. The child's report card citizenship rating as to Personal, Social, and Work and Play Habits; and the results of the rating scale of personality by four teachers have been discussed. A review of the child's own estimate of himself revealed interesting outcomes.

\section{Pupil Questionnaire}

A questionnaire of 65 questions (Table II Appendix) was given to the pupils. These were marked and tabulated. Fifteen of these questions were selected to be discussed as they follow the three headings, Personal, Social, and Work and Play Habits more closely. The following table will show the results of the questionnaire given to the children. 
RESULTS OF PERSONALITY QUESTIONNAIRE GIVEN FORTY CHILDREN FROM INSTITUTIONS AND FORTY FROM PRIVATE HOMES

Questions
Institutional Private Home

Yes No Some times

Yes No Some times

PERSONAI HABITS

1 Are you prompt in turning in your assignments?

2 Do you give daily care to your hair, nails, teeth and skin?

3 Do you try to meet the daily food requirements of a balanced diet?

4 Are you careful not to say or do things that might huty others?

5 Are you easily excited and lose self control in unusual situations? Total

$\begin{array}{llllll}28 & 9 & 3 & 18 & 8 & 24\end{array}$

2515

3010

40

40

35

5

30

$\begin{array}{lllll}20 & 10 & 10 & 25 & 15\end{array}$

$\begin{array}{lllll}148 & 34 & 18 & 143 & 35\end{array}$

32

SOCIAL HABITS

1 Do people find fault with you more than you deserve?

2 can you stand criticism without hurt feelings?

3 Have you liked most of your teachers?

4 Do you get along well with your sisters, brothers, and companions?

5 Do you prefer to have one friend at a time?

6 Have you been selected as a leader of a group this term?

7 Do you like to be by yourself a great deal?

8 Do you ever féel lonesome even when people are around?

9 Does it bother you to have your teacher watch you work?

10 Are books more interesting than people?

Total

$\begin{array}{lll}34 & 3 & 3\end{array}$

23152

364

$\begin{array}{lll}26 & 9 & 7\end{array}$

15205

1030

35

308

2812

634 208170

WORK AND STUDY HABITS

I Does every little noise disturb you when you study?

2 Do you find it hard to keep your mind on what you are studying?

3 Do you depend upon others to plan your work and play?

4 Do you try to do promptly what needs to be done?

5 Is your work neatly and carefully done?

Total
$18 \quad 22$

2020

2510

5

2020

1810

10182

12
2413

2810

40

1720

2020

2317

830

2

364

3010

2 38 228162

10
3010

1228

1030

1525

2020

87113 
Symonds states very briefly the benefits of a questionnaire in rating personality:

$$
\begin{aligned}
& \text { "A type of diagnosis which promises to } \\
& \text { be fruitful in discovery of problem } \\
& \text { children is the questionnaire. This } \\
& \text { method tends to supplement rather than } \\
& \text { duplicate the ratings of associates. } \\
& \text { When rating methods tend to discover } \\
& \text { these with behavior difficulities } \\
& \text { on the basis of reputation, question- } \\
& \text { naires and self rating methods help } \\
& \text { discover those who feel unhappy or } \\
& \text { maladjusted. This is an important } \\
& \text { distinction. Rating methods isolate } \\
& \text { those who are behavior problems; } \\
& \text { the questionnaire, those with per- } \\
& \text { sonality problems. Those who are } \\
& \text { identified as problems by ratings } \\
& \text { methods tend to be those with extro- } \\
& \text { vert methods of adjustment; those } \\
& \text { who admit their unhappiness tend to } \\
& \text { be those with introvert methods of } \\
& \text { adjustment." l }
\end{aligned}
$$

The questions on this questionnaire, Table $X X X V$, could be answered only by the child and there is no possible check as to accuracy of the asawers. Yet it is quite interesting to see how these answers coincide with the ratings made by the teachers in Table VI.

In answering questions as to the Personal Habits, we find the institutional children checking 148 answers in the affirmative as against 143 from private homes. The greatest difference was in being able to decide whether they were prompt in turning in their assignments. In this instance a great number from the private homes checked this answer, sometimes.

1

Percival Symonds, Psychology Diagnosis in Social Adjustment, p. 49 . 
If this great number had decided in the affirmative or negative the picture would have been different. The children from the orphanage thought they had more control of themselves than the other group. Twenty in the affirmative, ten in the negative, and ten stated that they had perfect control sometimes, while there was no doubt in the private home group, twenty-five saying they usuallu had self control and fifteen saying they did not. There was practically no difference in the groups consideration of other people's geelings. Most students stated they were careful so as not to say things to hurt others.

As to Personal Habits, the children rated themselves practically equal, but this was not so when their Social Habits were tabulated as the private home group had a total of 228 against 208 for the institutional group. In answer to the question, "Do people find fault with you more than you deserve?" thirty-six orphangers answered in the affirmative to twentyfour in the private bomes. The affirmative answers given to the next question, "Can you stand criticisn without hurt feelibgs?" was given by the twenty-threo children from the institution. These two answers were not consistentas one who could accept criticism should not resent being criticised. The orphans felt that they get along well with their brothers, sisters, and companions, yet according to the teachers' estimate 
we would led to question the affirmative answers. Twentythree persons from the private homes had been selected as leaders during the term contrasted with ten from the institution. This agreed with the idea of the teachers mentioned earlier, that the orphans needed definite training in developing leadership abiljty.

Not one institutional child stated that he wished to be alone a great deal, and most of them stated that they liked to have several friends, instead of just one companion at a time. Fight people from the private homes stated that they enjoyed playing alone and it was a twehty-twenty vote as whether they preferred one friend or several. It was a wholesome fact to find that most children found people more interesting than books. Only six orphans preferred books to associating with people, and two children from the private homes thought books more interesting than poople. The institutional children felt that were congenial with their friends while twenty of the other children stated that they did not get along well with their playmates. In the Work and Play Habits, it was noticed that the children of the institution said that they depended on others to plan their work for them in a greater proportion than children from the private homes. This conld be due to the fact that such organization of recreation needed in the Home was not always the child's choice. Aside from this fac- 
tor there was very little difference in the responses fro $\mathrm{m}$ the two groups on the Work and Play Habits.

It was notized while compiling the answers to the questionnaire that the children from the private homes seemed to be able to decide on a definite answer more readily as they had only 42 responses marked "sometimes" in contrast to the institutional children who had 69. In the margin of the questionnaire several institutional children wrote additional explanations to their answers. This showed that there was a lack of self confidence and sense of personal worth in deciding upon the answers.

The results of the complete questionnaire may be found in the appendix, Table III.

\section{Summery}

1. Thirty-eight percent of the private home group were rated unsatisfactory by four sixth grade teachers as to personal appearance compared with tenty percent from the institutional group.

2. The institutional group had a careful inspection of their perso nal appearance every morning. Since 63 percent. of the forty families of the private home children had both parents working the children lacked supervision and assistance in caring for their personal appearance. 
3. Ten percent more of the institutional children were rated unsatisfactory in the Social Habit than the private home group.

4. In social activities the teachers considered the institutional children clannish and found that they formed a separate group from other children of the classroom.

5. Lack of self reliance and initiative was shown by 50 percent of the institutional group compared with 20 percent from the private gomes.

6. Sixty-three percent of the institutional children were budged as lacking in originality compared with 17 percent from private homes.

7. There was a difference of only 5 percent in the teacher rating of "Emotional Control" in favor of the institutional pupils.

8. The private home group was superior in the rating of "Shows Good Sportsmanship".

9. The pupils from the institution were believed to make better use of their time during the school hours than the private home group. 


\section{RECOMMEINDATIONS}

The results of this study surprised the writer, who had over a period of years definitely felt that there were significant differences between institutional and private home children. The findings of this comparison between the two groups revealed that there were no significant difference in the intelligence scores, the chronological ages and the scholarship achievements. Since the marked differences were found in the social characteristics the recomendations. will deal with development of this factor.

More reflective thinking, more student participation, more individual responsibility are stressed as factors much needed by both the institutional and private home children.

Students should have a major responsibility in planning their own programs, and opportunities of learning by living with other pupils.

Since it was found that the institutional children were clannish an effort might be made to try to break down this trait by securing the cooperation of the institution in allowing the children the advantages of participating in the extra curriculum activities such as, using the Public libraries, attending symphony concerts and lectures, and taking part in the intramural games.

The writer agrees with the recommendations made by 
the Child Welfare League of America in reference to the Baptist Home.

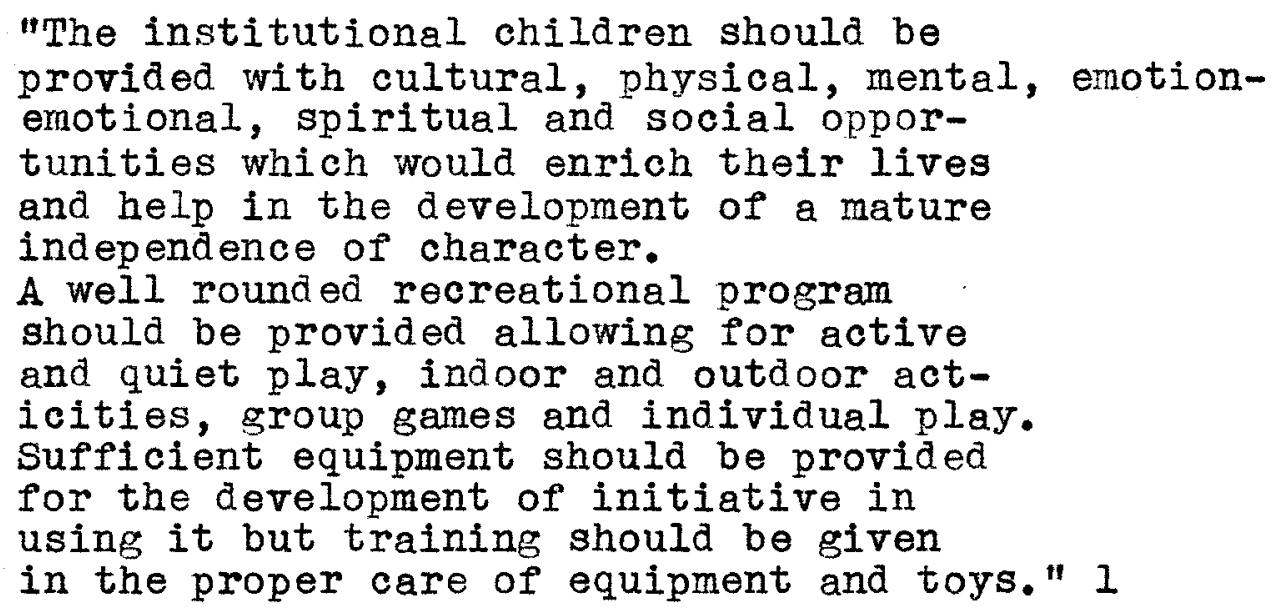

The children from the private homes should be trained more effectively in the correct use of leaiure time because 63 percent of the parents worked and the children were with out supervision. It is possibie that many extra curricular activities such as, clubs, intramural activities, art slasses, scout organizations, choral work and folk dances are effective for this purpose.

A longer school day and an enrichnent program of extra curricular activities in late afternoon and evening would keep the children off the streets and give proper supervision.

In the classroom in order to counteract the regimentation under which the children live in the institution the teacher should develop the individual personalities for living effectively in a democracy by providing preparation for self direction, self discipline and social responsibility.

\footnotetext{
1

Child Welfare of League of America, Repert of the $V$ Survey of the Louisville Baptist Orphan's Home.
} 
APPIIDIX 


\section{APPENDIX}

\section{TABLE I}

RESULT OF THE PROGRESSIVE ACHI EVEMENT TEST

FORMS B AND C ADMINISTERED OCTOBER 1943 - JANUARY 1944

TO FORTY PRIVATE HOME CHILDREN ENROILED IN A PUBLIC SCHOOL

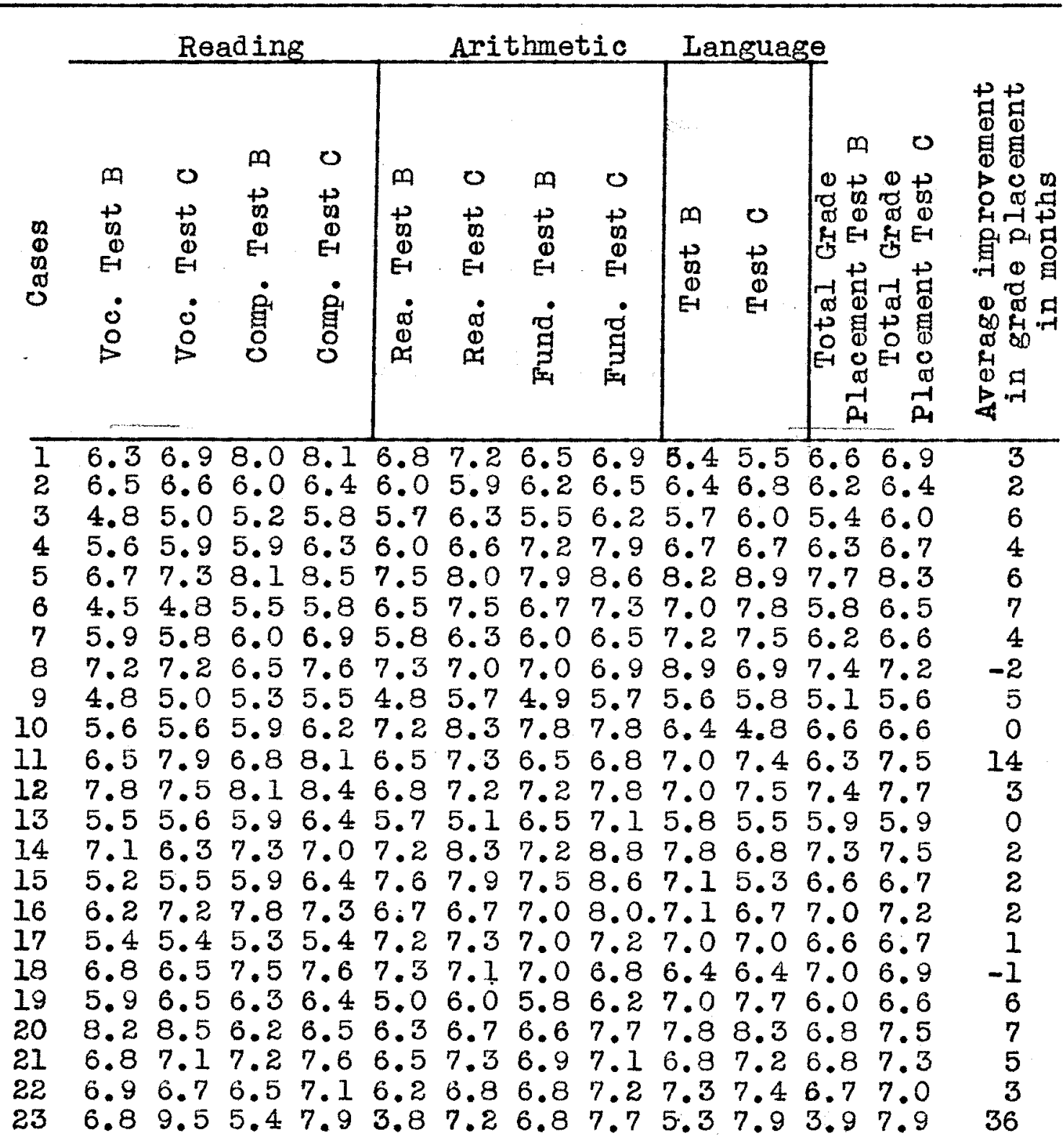




\section{TABLE I (continued)}

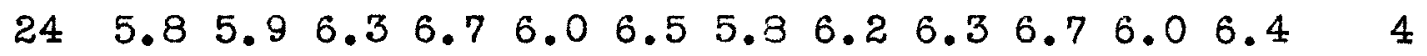

$256.06 .36 .76 .96 .27 .36 .7 \quad 7.4 \quad 7.4 \quad 7.6 \quad 6.5 \quad 7.1 \quad 6$

$\begin{array}{lllllllllllllll}26 & 6.7 & 6.9 & 6.1 & 7.2 & 5.8 & 6.7 & 6.9 & 7.3 & 7.0 & 7.8 & 6.3 & 7.2 & 9\end{array}$

$\begin{array}{lllllllllllllll}27 & 7.3 & 7.3 & 6.5 & 7.6 & 7.3 & 7.0 & 7.0 & 6.9 & 8.9 & 6.9 & 7.4 & 7.2 & -2\end{array}$

$\begin{array}{llllllllllllll}28 & 5.8 & 6.2 & 6.2 & 6.7 & 6.3 & 6.6 & 6.7 & 7.2 & 6.5 & 6.8 & 7.4 & 6.8 & 5\end{array}$

$\begin{array}{llllllllllllll}29 & 6.8 & 7.0 & 6.4 & 7.0 & 6.1 & 6.7 & 6.7 & 7.1 & 7.2 & 7.3 & 6.6 & 7.0 & 4\end{array}$

$\begin{array}{llllllllllllll}30 & 5.8 & 6.0 & 6.3 & 6.8 & 6.2 & 6.4 & 6.0 & 6.5 & 6.5 & 7.2 & 6.1 & 6.6 & 5\end{array}$

$\begin{array}{llllllllllllllll}31 & 5.9 & 7.6 & 5.5 & 6.0 & 6.0 & 6.3 & 5.2 & 5.7 & 7.0 & 7.4 & 5.9 & 6.6 & 7\end{array}$

$\begin{array}{lllllllllllllll}32 & 7.2 & 7.5 & 8.0 & 8.3 & 6.5 & 7.0 & 6.4 & 7.0 & 6.4 & 8.1 & 6.9 & 7.6 & 7\end{array}$

$\begin{array}{llllllllllllll}33 & 6.5 & 6.9 & 7.0 & 7.5 & 5.1 & 5.2 & 5.9 & 6.2 & 7.5 & 8.3 & 6.4 & 6.8 & 4\end{array}$

$\begin{array}{lllllllllllllll}34 & 7.5 & 8.2 & 8.0 & 8.5 & 6.5 & 8.3 & 6.8 & 8.5 & 7.5 & 9.0 & 7.2 & 8.5 & 15\end{array}$

$\begin{array}{llllllllllllll}35 & 8.2 & 7.8 & 6.9 & 6.7 & 6.5 & 6.7 & 8.2 & 8.1 & 8.2 & 8.9 & 7.9 & 8.7 & 8\end{array}$

$\begin{array}{llllllllllllll}36 & 11 . & 9.5 & 7.9 & 8.6 & 7.4 & 7.2 & 7.8 & 9.6 & 8.8 & 9.2 & 8.6 & 8.8 & 2\end{array}$

$\begin{array}{llllllllllllll}37 & 5.6 & 5.3 & 5.9 & 6.5 & 7.2 & 8.3 & 7.8 & 7.8 & 6.4 & 4.8 & 6.6 & 6.6 & 0\end{array}$

$\begin{array}{lllllllllllllll}38 & 9.3 & 8.6 & 7.6 & 8.6 & 6.2 & 5.8 & 6.7 & 6.8 & 4.7 & 5.6 & 6.9 & 7.1 & 2\end{array}$

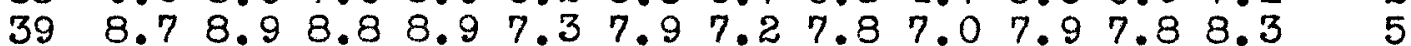

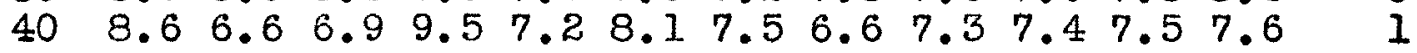

Median $6.56 .76 .57 .16 .57 .06 .7 \quad 7.17 .07 .46 .67 .115$ 


\section{APPENDIX}

\section{TABLE II}

RESULT OF THE PROGRESSIVE ACHIEVEMETNT TEST

FORMS B AND C ADIUINISTERED OCTOBER 1943 - JANUARY 1944 TO FORTY INSTITUTIONAL CHILDREN EMROLLED IN A PUBLIC SCHOOL

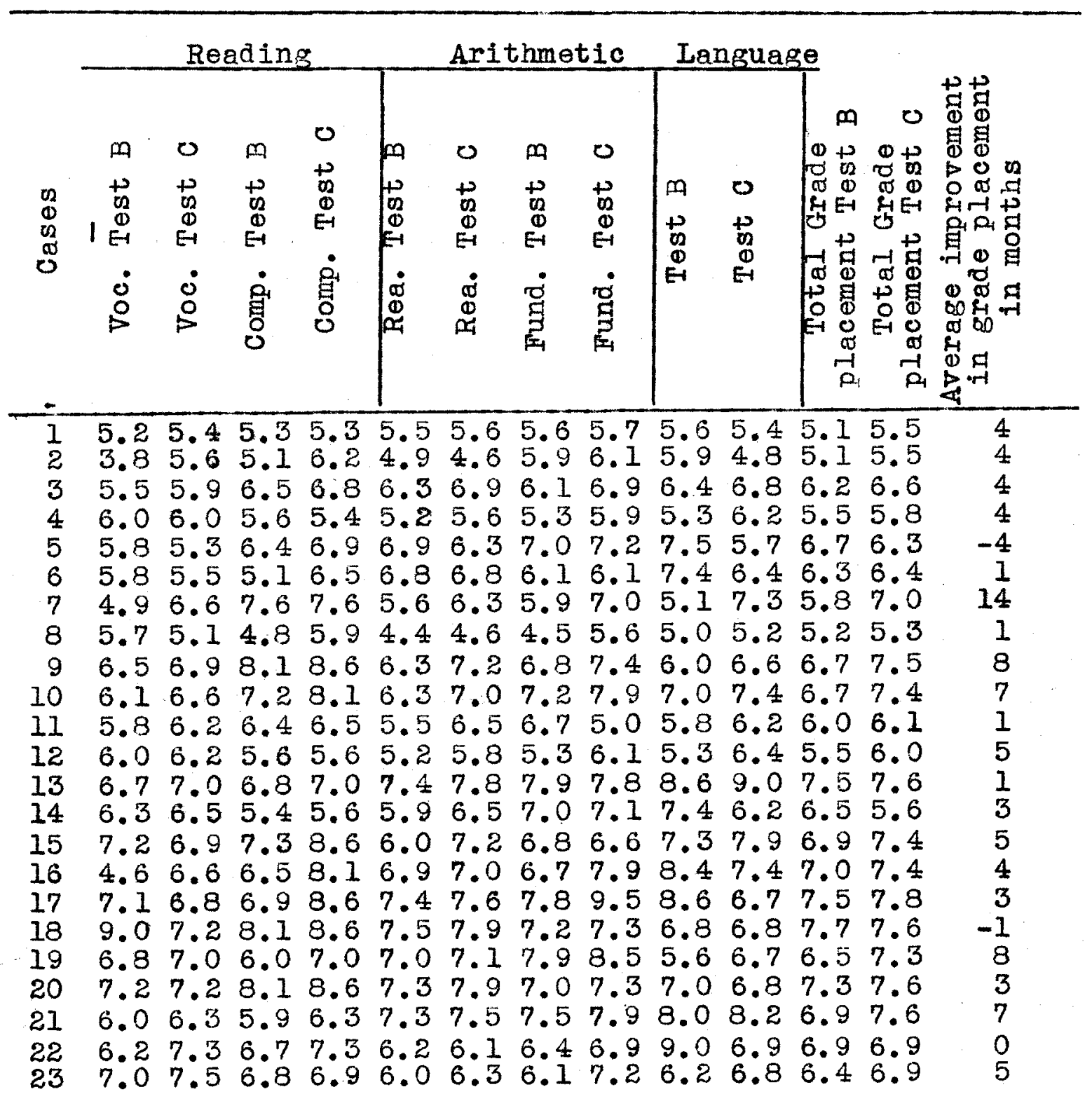




\section{TABLE II (continued)}

$\begin{array}{rllllllllllllllll}24 & 5.7 & 6.5 & 6.4 & 5.7 & 6.0 & 6.1 & 7.3 & 6.9 & 7.0 & 5.9 & 6.4 & 6.2 & -2 \\ 25 & 5.0 & 5.4 & 4.7 & 5.8 & 5.0 & 7.3 & 5.8 & 6.8 & 4.8 & 6.5 & 5.1 & 6.5 & 16 \\ 26 & 6.0 & 6.8 & 7.0 & 8.6 & 6.0 & 7.6 & 7.1 & 9.5 & 6.2 & 6.7 & 6.4 & 7.8 & 16 \\ 27 & 3.8 & 6.5 & 5.5 & 6.7 & 4.6 & 6.3 & 6.1 & 6.5 & 6.8 & 6.6 & 5.6 & 6.5 & 9 \\ 28 & 5.0 & 6.3 & 7.1 & 6.8 & 6.0 & 7.5 & 6.3 & 7.3 & 6.8 & 7.0 & 6.7 & 6.3 & 6 \\ 29 & 7.2 & 7.3 & 7.0 & 8.1 & 6.4 & 6.7 & 7.5 & 7.7 & 7.2 & 7.3 & 7.1 & 7.4 & 3 \\ 30 & 4.6 & 4.5 & 5.0 & 5.2 & 4.7 & 5.8 & 5.5 & 5.8 & 3.9 & 6.9 & 4.8 & 5.6 & 8 \\ 31 & 8.9 & 6.9 & 7.2 & 7.0 & 5.9 & 6.5 & 6.7 & 7.4 & 8.1 & 7.8 & 7.2 & 7.1 & -1 \\ 32 & 4.2 & 5.8 & 6.7 & 6.8 & 6.0 & 6.3 & 5.8 & 5.8 & 4.7 & 5.6 & 5.4 & 6.1 & 2 \\ 33 & 9.0 & 7.5 & 7.9 & 6.9 & 7.3 & 6.3 & 7.8 & 7.2 & 7.4 & 7.9 & 7.4 & 6.7 & -14 \\ 34 & 7.3 & 8.0 & 8.0 & 8.2 & 7.5 & 8.0 & 6.9 & 7.4 & 7.0 & 7.8 & 7.3 & 8.0 & 7 \\ 35 & 6.9 & 7.8 & 9.0 & 8.6 & 6.9 & 8.7 & 6.8 & 8.9 & 7.3 & 7.0 & 7.4 & 8.2 & 8 \\ 36 & 7.4 & 7.3 & 6.7 & 7.9 & 5.5 & 8.1 & 7.4 & 7.7 & 6.8 & 6.9 & 6.7 & 7.6 & 9 \\ 37 & 6.3 & 6.5 & 6.0 & 7.3 & 5.5 & 5.5 & 6.3 & 6.2 & 7.8 & 7.0 & 6.4 & 6.5 & 1 \\ 38 & 6.7 & 6.2 & 5.0 .9 .5 & 6.2 & 7.8 & 7.1 & 8.2 & 7.0 & 5.8 & 6.4 & 7.5 & 13 \\ 39 & 7.3 & 9.5 & 6.5 & 9.0 & 7.410 .0 & 7.9 & 8.9 & 7.9 & 7.8 & 7.4 & 8.8 & 16 \\ 40 & 7.2 & 7.3 & 8.6 & 8.2 & 5.1 & 5.8 & 6.4 & 7.3 & 7.0 & 7.5 & 6.9 & 7.2 & 6\end{array}$

Median $6.16 .5 \quad 6.6 \quad 6.96 .06 .8 \quad 6.7 \quad 7.46 .8 \quad 7.06 .4 \quad 7.0 \quad 6$ 


\section{TABLE III}

QUESTIONNAIRE GIVEN TO THE CHILDREN

\begin{tabular}{|c|c|c|c|c|c|c|}
\hline & \multicolumn{3}{|c|}{ Institution } & \multicolumn{3}{|c|}{ Private Home } \\
\hline & Yes & No & $\begin{array}{l}\text { Some } \\
\text { times }\end{array}$ & Yes & No & $\begin{array}{l}\text { Some } \\
\text { times }\end{array}$ \\
\hline 1. Do you have an income? & 20 & 20 & & 25 & 10 & 5 \\
\hline 2. Do you earn money regularly & 15 & 25 & & 20 & 20 & \\
\hline 3. Do you save money each week & 15 & 5 & & 10 & 30 & \\
\hline 4. Do you like to play alone? & 7 & 30 & 3 & 5 & 15 & 10 \\
\hline $\begin{array}{l}\text { 5. Do you usually control } \\
\text { your temper? }\end{array}$ & 12 & 25 & 3 & 27 & 10 & 3 \\
\hline $\begin{array}{l}\text { 6. Do you get along well with } \\
\text { your brothers, sisters? }\end{array}$ & 26 & 9 & 5 & 17 & 20 & 3 \\
\hline $\begin{array}{l}\text { 7. Do you find it hard to } \\
\text { start a conversation } \\
\text { with a stranger? }\end{array}$ & 29 & 8 & 3 & 17 & 25 & 8 \\
\hline 8. Do you laugh easily? & 36 & 3 & 1 & & & \\
\hline $\begin{array}{l}\text { 9. Are you careful not to say } \\
\text { or do things that might } \\
\text { hurt others? }\end{array}$ & $35^{\prime}$ & 0 & 5 & 30 & 2 & 8 \\
\hline $\begin{array}{l}\text { 10. Do you ever feel lonesome } \\
\text { even when people are near? }\end{array}$ & 30 & 8 & 2 & 36 & 4 & \\
\hline $\begin{array}{l}\text { 11. Are you interested in mak- } \\
\text { ing new friends? }\end{array}$ & 34 & 0 & 6 & 40 & 0 & 0 \\
\hline $\begin{array}{l}\text { 12. When a new person comes to } \\
\text { your room do you go and try } \\
\text { to make new friends at once }\end{array}$ & elo & 10 & 20 & 30 & 0 & 10 \\
\hline $\begin{array}{l}\text { 13. Would you rather have just } \\
\text { one good friend at a time? }\end{array}$ & 15 & 20 & 5 & 25 & 5 & 5 \\
\hline
\end{tabular}


TABLE III (continued)

Yes No Some Some

\begin{tabular}{cccccccc} 
& & & times & Yes No times \\
\hline $\begin{array}{c}\text { 14. Are books more interesting } \\
\text { to you than people? }\end{array}$ & 6 & 34 & 0 & 2 & 38 & 0
\end{tabular}

15. Are your feelings easily hurt?

$20 \quad 8 \quad 12 \quad 28 \quad 10 \quad 2$.

16. Do people find fault with $\begin{array}{lllllll}\text { you more than you deserve? } & 36 & 3 & 3 & 24 & 13 & 2\end{array}$

17. Do you feel tired when tou $\begin{array}{llllll}\text { wake up in the morning? } & 3 & 33 & 4 & 6 & 34\end{array}$

18. Are you often frightened in the middle of the night?

40

40

19. Do you day dream?

$\begin{array}{llllll}25 & 10 & 5 & 20 & 2 & 18\end{array}$

20. Were you your parent's favorite child?

$436 \quad 0$

$13 \quad 15 \quad 12$

21. Do you like to be by your self a great deal?

$35 \quad 5$

$\begin{array}{lll}8 & 30 & 2\end{array}$

22. Did you ever have a strong desire to run away from home?

20

$\begin{array}{llllll}12 & 8 & 10 & 30 & 0\end{array}$

23. Does it bother you to have your teacher watch you do your work even if you can do it well?

$28 \quad 12$

$30 \quad 10$

24. Can you stand criticism without feeling hurt?

$23 \quad 15 \quad 2$

$\begin{array}{lll}28 & 10 & 2\end{array}$

25. Can you stand kidding or teasing?

$20 \quad 12 \quad 8$

$12 \quad 16 \quad 18$

26. Are you absentminded?

$\begin{array}{lll}15 & 15 & 10\end{array}$

$\begin{array}{lll}10 & 25 \quad 5\end{array}$

27. Do you make friends easily?

$20 \quad 6 \quad 14$

$35 \quad 5$ 
TABLE III (continued)

Yes No Some Yes No Some

times times

28. Do you feel tired most of the time?

38

2

40

29. Are you usually in good spirits?

40

40

30. Do you feel embarrassed $\begin{array}{lllllll}\text { when you recite in class? } & 20 & 5 & 15 & 15 & 15 & 10\end{array}$

31. Do you hesitate to recite in class even when you know the answer?

$20 \quad 15 \quad 5$

$25 \quad 15$

32. Are you shy with girls?

40

40

33. Do you like to work out doors?

$35 \quad 5$

$25 \quad 10 \quad 5$

34. Do you like to solve puzzles?

$25 \quad 15$

$35 \quad 5$

35. Are you slow to decide thinglo 30

$5 \quad 35$

36. Have you like most of the teachers you have had at school?

$36 \quad 4$

40

37. Do you have a great many friends?

$35 \quad 5$

$30 \quad 10$

38. Do you have any special work at home which you do for your mother?

39. Are you often disobedient at home?

238

40

40. Have you been punished the last week for some misbehavior?

$\begin{array}{lllll}3 & 30 & 7 & 10 & 30\end{array}$

41. Have you ever smoked?

$5 \quad 35$

$8 \quad 32$

42. Did your parents know that you smoked?

32

35 
Yes No Some Yes No Some

43. Do you have a room of your own 40 times times

44. Do you study with the rest of the family in the same room?

45. Do you usually have some one to help you with your lessons?

46. Do you prefer to have one friend at a time rather than many?

$\begin{array}{lllll}15 & 20 & 5 & 20 & 20\end{array}$

47. Do you study with the radio turned on?

40

$\begin{array}{lll}5 & 15 & 20\end{array}$

48. Did you go to Sunday School or church last Sunday?

$38 \quad 2$

$25 \quad 15$

49. Does your mother or matron go to church with you most of the time?

50. Do you study your sunday School lesson?

$25 \quad 15$

1220

6

51. Does your mother or matron choose the shows that you see?

52. Are you a member of any clubs?

53. Do you hold any offices at school?

54. Have you ever been an officer in any organization at Sunday School?

55. Do you have a hobby?

$10 \quad 30$

$20 \quad 20$ 


\section{TABLE III (continued)}

$$
\text { Yes No Some Yes No Some }
$$
times times

56. Do you listen to a news broadcast every day?

$\begin{array}{llllll}5 & 23 & 12 & 10 & 20 & 10\end{array}$

57. Are you easily excited or lose self control $\begin{array}{llllll}\text { when unusal things happen? } & 20 & 10 & 10 & 25 & 15\end{array}$

58. Have you been selected as a leader of a group this term?

$\begin{array}{llll}15 & 25 & 23 & 17\end{array}$

59. Are you prompt in turn$\begin{array}{lllllll}\text { ing to your assignments? } & 28 & 9 & 3 & 18 & 8 & 14\end{array}$ 60. Do you try to meet the daily
food requirements?

61. Do you give daily care to your hair, nails, teeth and skin?

62. Do you depend upon others to plan your work and plays25 $10 \quad 5 \quad 10 \quad 30$

63. Do you find it hard to keep your mind on what you are doing?

$20 \quad 20$

$12 \quad 28$

64. Is your work usually neat and carefully done?

$\begin{array}{lllll}18 & 10 & 12 & 20 & 20\end{array}$

65. Does every little noise disturb your thoughts when you work? 


\section{BIBLIOGRAPHY}

A BOOKS

Cooper, John, Children's Institutions, Dolphin Press, 1931, p. 415 .

Crow, Lester and Crow, Alice, Mental Hygiene in School, McGraw-Hill Book Company, New York, 1942, p.426.

Culbert, Jane F., The Visiting Teacher, New York: The Common Wealth Fund, 1929

Dunlap, J.W., amd Kurtz, A.L., Handbook of Statistical Nomograph, Tables and Formulas, Yonkers on Hudson, World Book Company, 1932

Gate, Jerseld, McConnell, Challman, Educational Psychology, MacMillan Company, New York, 1942

Kilpatrick, W.H., A Reconstructed Theory of the Education Process, Bureau of Publication, Teacher's College Columbia University, 1935, pp.3-7.

Lincoln, E. A., Sex Differences in Growth of American School Children, Warwick and York, 1936, p.48

McLester, Amelia, Development of Character Traits in Young Children, Charles Scribner and Son, New York, 1931, C.1-2

Plant, James S., Personality and the Cultural Pattern, Comnonwealth Fund, New York, 1939 
Robinson, Sophia, Can Delinquency Be Measured? The Welfare Council of New York, Columbia University, 1936, p.127

Shaw, Clifford R., Delinquency Area, Chicago University Press, Chicago, 1929

Skeels, H.M., A Study of Invironmental Stimulation, University of Iowa Studies in Child Welfare, Vol. 16, No.I, 1939

Slingerland, W.H., Child Welfare Work in Louisville, Welfare League, 1919

Strang, Ruth, The Roll of Teacher in Personal Work, Teacher's College, New York, 1935, pp.364-365

Teagarten, Florence, Child Psychology for the Professional Worker, Frentice Hall, Inc., New York, 1940, p.453

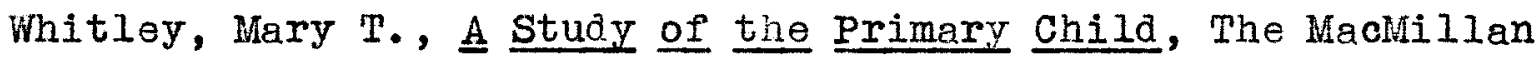
Company, New York, p. 18 


\section{B MAGAZINES}

Addition, Henrietta, "Bad Girl Had a Bad Home", Louisville Courier Journal, July 23, 1944

Bernard, Viola, "Detention and Management of Emotional Disorders", Mental Eygiene, July, 1942

Burnham, W.H., "Sex Differences in Mental Ability", Educational Review, 152, November, 1921, p.280

Louisville Block Statistics, prepared by Dr. Leon Truesdell, United States Government, Printing office, 1942

National Society for Study of Education-Yearbook XXVII, part I "The Influence of Environment on Intelligence, School Achievement and Conduct of Foster Children", by Frank Freeman, Karl Holziner, Blythe Mitchell

National Society Por Study of Education-Yearbook XXVII, "Nature and Nurture Their Influence Upon Intelligence", Burks, Barbar S., 1928

Pressey, L.W., "Sex Differences Shown by 2544 School Children on a Scale of Intelligence", Journal of Applied Psychology, II, November, 1918, p.224

Record of School District Lines, Files of Superintendent's Office, Louisville Board of Education, September, 1943 
Welfare League of America, "Report of the Survey of the Louisville Baptist Home", New York City, September, 1943 Wreschner, A., "New Studies and Hental Difference Between Boys and Girls", Review of Reviews, Vol.63, July, 1923, p.104 